\title{
Albian to Turonian agglutinated foraminiferal assemblages of the Lower Saxony Cretaceous sub-basins - implications for sequence stratigraphy and paleoenvironmental interpretation
}

\author{
Richard M. Besen ${ }^{1}$, Ulrich Struck ${ }^{1,2}$, and Ekbert Seibertz ${ }^{3}$ \\ ${ }^{1}$ Department of Earth Sciences, Institute of Geological Sciences, Freie Universität Berlin, \\ Malteserstraße 74-100, 12249 Berlin, Germany \\ ${ }^{2}$ Museum für Naturkunde Berlin, Leibniz Institute for Evolution and Biodiversity Science, \\ Invalidenstraße 43, 10115 Berlin, Germany \\ ${ }^{3}$ Institute of Geoecology, University of Braunschweig, Langer Kamp 19c, 38106 Braunschweig, Germany \\ Correspondence: Richard M. Besen (r.besen@fu-berlin.de)
}

Received: 9 August 2021 - Revised: 12 November 2021 - Accepted: 12 November 2021 - Published: 17 December 2021

\begin{abstract}
Albian to Turonian carbonate deposits at three different locations of the Lower Saxony Cretaceous and thereby of the European mid-Cretaceous epeiric shelf sea were investigated for their fossil agglutinated foraminiferal fauna. In this study, 71 samples from two quarries and three drill cores were treated with formic acid, which enabled the study of agglutinated foraminiferal assemblages even in highly lithified limestones. In total, 114 species were determined and classified as belonging to nine morphogroups. In general, four agglutinated foraminiferal assemblages are distinguished: (1) an uppermost Albian-lowermost Cenomanian assemblage from the Wunstorf drill cores, with the dominant taxa Bathysiphon spp., Nothia spp., Psammosphaera fusca, Reophax subfusiformis, Bulbobaculites problematicus, Tritaxia tricarinata, Flourensina intermedia, Vialovella frankei, Arenobulimina truncata, and Voloshinoides advenus; (2) a Cenomanian assemblage from the Baddeckenstedt quarry and Wunstorf drill cores, with Ammolagena clavata, Tritaxia tricarinata, Vialovella frankei, Arenobulimina truncata, and Voloshinoides advenus; (3) an assemblage related to the Cenomanian-Turonian Boundary Event in Wunstorf and Söhlde dominated by Bulbobaculites problematicus; and (4) a Turonian assemblage in the Wunstorf and Söhlde sections with high numbers of Ammolagena contorta, Repmanina charoides, Bulbobaculites problematicus, Gerochammina stanislawi, and Spiroplectammina navarroana. The latest Albian-earliest Cenomanian assemblage consists of tubular, globular, and elongate foraminiferal mor-
\end{abstract}

phogroups which are typical for the low- to mid-latitude slope biofacies. All other assemblages are composed of elongate foraminiferal morphogroups with additionally globular forms in the proximal settings of Baddeckenstedt and Söhlde or flattened planispiral and streptospiral forms in more distal settings of Wunstorf. For these assemblages, a new agglutinated foraminiferal biofacies named "mid-latitude shelf biofacies" is proposed herein. Changes in the relative abundance of different morphogroups can often be referred to single features of depositional sequences. Furthermore, classical macro-bioevents, which are often depositional-related, of the Lower Saxony Cretaceous seem to have a micro-bioevent or acme equivalent of the agglutinated foraminiferal fauna.

\section{Introduction}

During the mid-Cretaceous, sedimentary sub-basins of Lower Saxony and the Subhercynian were part of a wide epeiric continental shelf sea connected with the Arctic realm, the young North Atlantic Ocean and central Atlantic Ocean, and the Tethys Ocean, which were separated by the MidEuropean Island (Janetschke et al., 2015). High relative sea level (Haq, 2014) and high relative temperatures (Voigt et al., 2004) favoured carbonate deposition in wide parts of these and other basins worldwide during that time (Skelton, 2003; Voigt et al., 2008a; Janetschke et al., 2015). Long-term sea level trends and changes in bottom water temperature, nu- 
trient availability, oxygen concentration of bottom waters, and paleoceanographical current patterns like those during the early Cenomanian transgression, Mid-Cenomanian Event (MCE), and Oceanic Anoxic Event 2 (OAE2)-Cenomanian Turonian Boundary Event (CTBE) made this time interval attractive for research (Skelton, 2003; Voigt et al., 2004, 2008a). To understand the sea level and depositional sequence coupling and other paleoenvironmental changes in the Lower Saxony Basin, investigations were made for the Albian (e.g. Fenner, 1996; Tyszka, 2009; Bornemann et al., 2017), for the Cenomanian (e.g. Wilmsen, 2003, 2007; Wilmsen et al., 2005; Voigt et al., 2006), for the CTBE (e.g. Linnert et al., 2010; Hetzel et al., 2011; Blumenberg and Wiese, 2012; van Helmond et al., 2015), and for the Turonian (Wiese et al., 2015). Most of these studies approach the former conditions in the upper water layers of this Cretaceous shelf sea by focussing on planktic foraminifers and calcareous nannofossils. Thus, to get a better understanding of the paleoenvironment of the mid-Cretaceous deposits of Lower Saxony, in particular additional information of the bottom water conditions is necessary.

The reconstructions of past bottom water conditions based on agglutinated foraminifera morphogroup analyses have been established by Jones and Charnock (1985) modified by Bąk et al. (1997), Peryt et al. (1997, 2004), Van Den Akker et al. (2000), and Murray et al. (2011). Our study follows the morphogroup scheme applied on Cretaceous foraminiferal assemblages by Frenzel (2000), Cetean et al. (2011), and Setoyama et al. (2017). Agglutinated foraminifers are widely used to investigate mid-Cretaceous deep-water deposits with focus on the Arctic realm (Gradstein et al., 1999; Setoyama et al., 2017), the Atlantic Ocean (Kuhnt et al., 1989, 1992; Kuhnt and Kaminski, 1997), and the Tethyan realm (Coccioni et al., 1995; Kaminski et al., 2011) with special accentuation on the Carpathians (Geroch and Nowak, 1984; Bubík, 1995; Bąk, 2007; Józsa et al., 2017a).

A detailed stratigraphic framework of the mid-Cretaceous of Lower Saxony exists (e.g. Ernst et al., 1983; Voigt and Hilbrecht, 1997; Wilmsen and Niebuhr, 2002; Wilmsen, 2003, 2007; Voigt et al., 2008b; Wiese, 2009; Bornemann et al., 2017; Erbacher et al., 2020) and is supported by correlations of stable carbon isotope patterns of the Wunstorf drill cores conducted in this study. This framework allows a precise stratigraphic correlation of the agglutinated foraminiferal assemblages and their application as a proxy for paleoenvironmental reconstructions in a shelf setting with high carbonate production. Firstly, high lithified limestones of the Lower Saxony Cretaceous are investigated on their agglutinated foraminiferal content, whereas former studies focussed on less lithified marlstones to marly limestones (Frieg and Kemper, 1989). Therefore, the main objectives of the present study are the documentation of agglutinated foraminiferal assemblages and the linkage of the assemblage composition and palaeoenvironmental information provided by former studies. Furthermore, the biostratigraphical util- ity of agglutinated foraminifers for the basins is examined by applying existing biostratigraphical schemes (Geroch and Nowak, 1984; Frieg and Kemper, 1989; Hart et al., 1989; Kuhnt and Kaminski, 1997; Kaminski et al., 2011) and assessing regional biomarkers and agglutinated foraminiferal acmes.

\section{Geology and lithostratigraphy}

\subsection{Geological overview}

The study area is located in the southern part of Lower Saxony (northern Germany), comprising the Lower Saxony and Subhercynian Cretaceous sub-basins (Fig. 1). These were part of a wide epicontinental shelf sea that spanned large parts of the middle to north European shelf area. This shelf sea was bordered in the south by the Mid-European Island, in the north by the Fennoscandian Shield, and in the west by several smaller land masses (Fig. 1). To the east the shelf sea reached onto the Russian Platform (Skelton, 2003; Voigt et al., 2008a; Janetschke et al., 2015). Widespread marine sediments were deposited in the Cenomanian to Turonian favoured by a major, second-order sea level highstand phase (Haq, 2014; Fig. 2). While nearshore, mainly siliciclastic-glauconitic sediments were deposited, offshore marl-limestone alternations to chalk deposits were formed.

During the late-early Cenomanian, water depths of 20$30 \mathrm{~m}$ in a proximal position at Baddeckenstedt of about $30-40 \mathrm{~km}$ distance from the shore and ca. $50 \mathrm{~m}$ at about $80-100 \mathrm{~km}$ from the former coastline at Wunstorf are assumed by Wilmsen (2003). During the CenomanianTuronian boundary, a water depth of $100-150 \mathrm{~m}$ is proposed.

\subsection{Studied sections}

\subsubsection{Wunstorf}

The Wunstorf-Kolenfeld quarry is located around $20 \mathrm{~km}$ west of Hanover with WGS84 coordinates $52.40146^{\circ} \mathrm{N}$, $9.48940^{\circ} \mathrm{E}$ at the quarry centre. The area belongs to the Wunstorf Cretaceous Syncline as part of the Lower Saxony Basin (Fig. 1). The Cretaceous strata dip at $15^{\circ}$ towards southwest. Three drill cores from an exploration campaign for the quarry surrounding area by Holcim (Deutschland) Höver $\mathrm{GmbH}$ were investigated in detail by Seibertz (2013; see Fig. 3; Wunstorf Wu2010/1 (WGS84) $52.405868^{\circ} \mathrm{N}, 9.496213^{\circ} \mathrm{E}, 51.50 \mathrm{~m}$ above sea level, $70 \mathrm{~m}$ core depth; Wunstorf Wu2010/3 (WGS84) $52.400093^{\circ} \mathrm{N}$, $9.484749^{\circ} \mathrm{E}, 51.70 \mathrm{~m}$ above sea level, $99 \mathrm{~m}$ core depth; Wunstorf Wu2010/4, (WGS84) 52.397263 ${ }^{\circ} \mathrm{N}, 9.479357^{\circ} \mathrm{E}$, $52.70 \mathrm{~m}$ above sea level, $101 \mathrm{~m}$ core depth) and compared to the Wunstorf quarry succession (Wilmsen, 2003) and three cores from former studies (Voigt et al., 2008b; Erbacher et al., 2020; Fig. 3). The Wunstorf Wu2010/1 (Fig. 4) core contains uppermost Albian to lower Cenomanian clay to marl- 


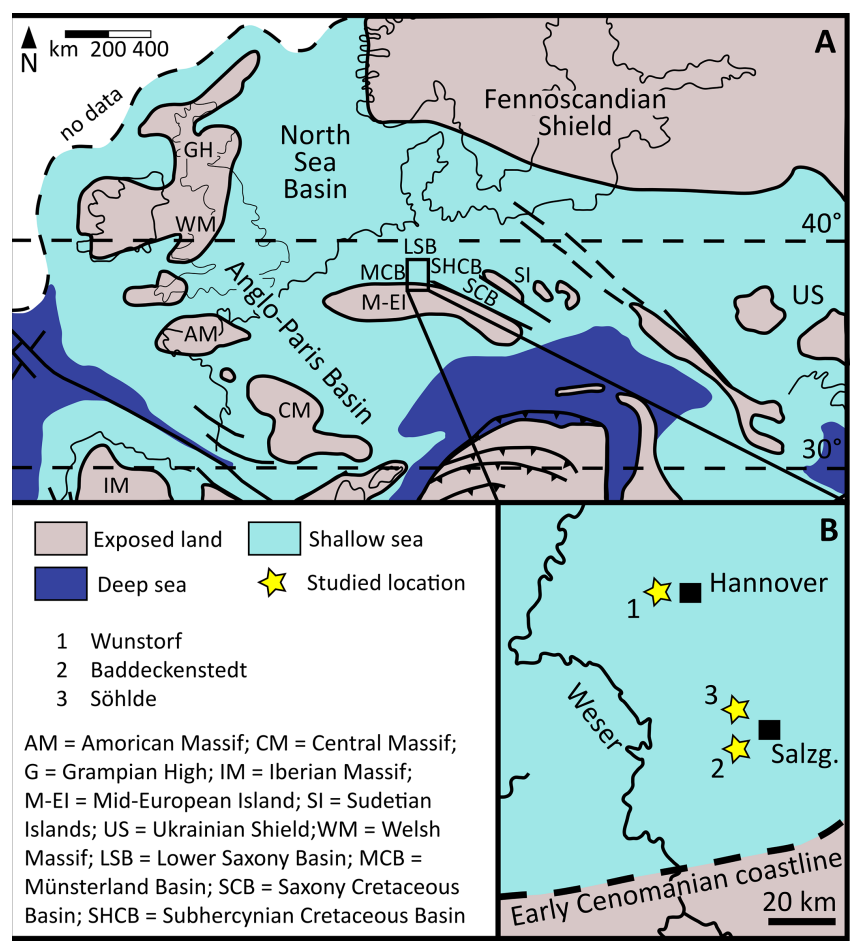

Figure 1. Paleogeographical map of Europe and the study area. (A) Paleogeography of Europe during the Cenomanian, modified after Philip and Floquet (2000). (B) Paleogeography of southern Lower Saxony during the early Cenomanian, modified from Wilmsen et al. (2021), base map from Hiss (1995).

stones of the Herbram Formation (70-15 m core depth). The Wunstorf Wu2010/3 core (Fig. 4) consists of ca. $23 \mathrm{~m}$ clay to marlstones of the Herbram Formation (95-72 m core depth) and about $47 \mathrm{~m}$ of marl-limestone alternations of the Baddeckenstedt Formation (72-25 m core depth). The Wunstorf Wu2010/4 (Fig. 5) core comprises $3 \mathrm{~m}$ of limestone of the Brochterbeck Formation (86-83 m core depth), $20 \mathrm{~m}$ of black shale-marlstone alternations of the Hesseltal Formation (83$63 \mathrm{~m}$ core depth), and $27 \mathrm{~m}$ limestones of the Söhlde Formation (63-36 $\mathrm{m}$ core depth). The detailed stratigraphical framework mainly based on stable isotope, event, and sequence stratigraphy and biostratigraphy applied to the quarry section and three drill cores is derived from Meyer (1990), Wilmsen (2003, 2007), Erbacher et al. (2007), Voigt et al. (2008b), Seibertz (2013), and Erbacher et al. (2020).

In the Wunstorf Wu2010/1 core, the ultimus/Aucellina Event could be identified at $54 \mathrm{~m}$ depth, and the prominent marker limestone The Rib at could be identified $15 \mathrm{~m}$ depth. The crippsi Event is probably located at a depth of $38 \mathrm{~m}$ (Seibertz, 2013; Fig. 4). The crippsi Event and The Rib were also recorded in the Wunstorf Wu2010/3 core at $94 \mathrm{~m}$ and $72 \mathrm{~m}$ depth respectively (Seibertz, 2013; Fig. 4). Both can be used for correlation; meanwhile the positions of other Cenomanian events remain doubtful.

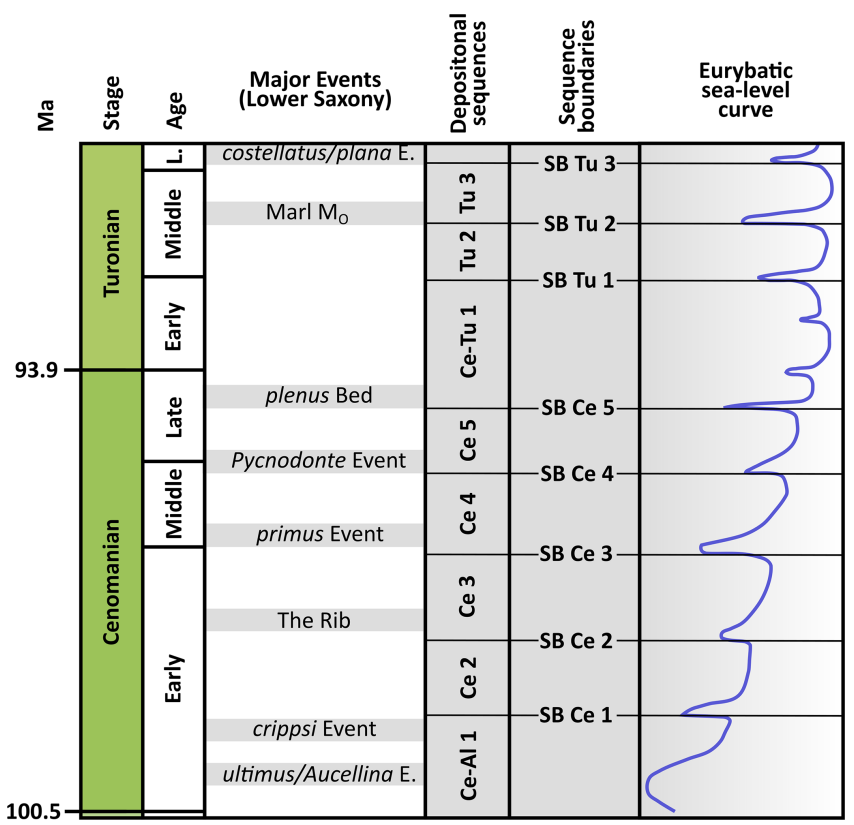

Figure 2. Chronostratigraphy, selected events, and depositional sequences as well as interpreted sea level curve of the Lower Saxony Cretaceous. Depositional sequences, associated sequence boundaries, and sea level curve are from Janetschke et al. (2015). Age of stage boundaries are from Gradstein et al. (2020).

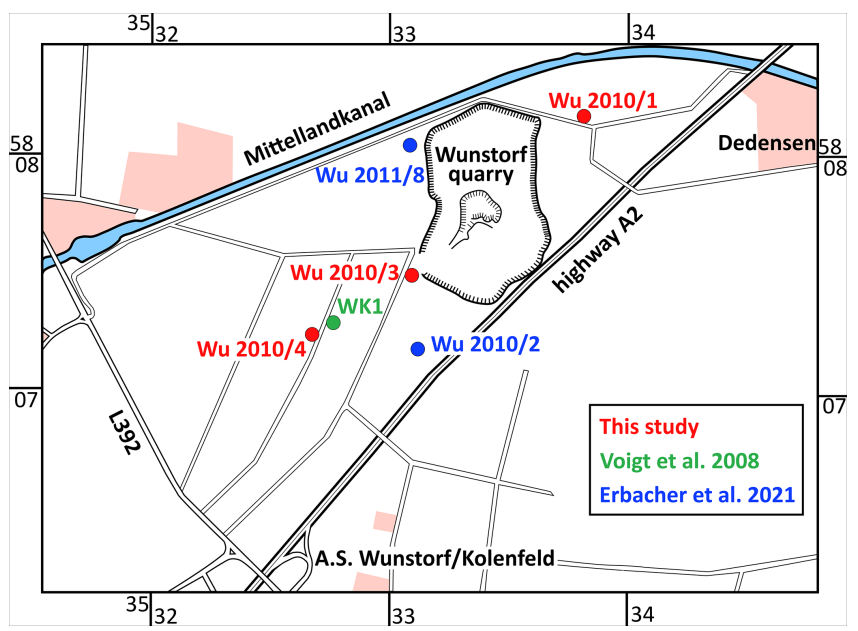

Figure 3. Schematic locality details of the study area of Wunstorf and position of the cores: green (Voigt et al., 2008b), blue (Erbacher et al., 2020), and red (this study). Modified from Seibertz (2013: Fig. 5).

Above the Facies Change ( $82 \mathrm{~m}$ core depth), the plenus Bed (81-79 m core depth), Fischschiefer (78-76 m core depth), Mytiloides events (at about $64 \mathrm{~m}$ core depth), Weiße Grenzbank (46-44 $\mathrm{m}$ core depth), and marl $\mathrm{M}_{0}$ (at about $44 \mathrm{~m}$ core depth) could be identified in the Wunstorf Wu2010/4 core. Above the Mytiloides events, slumping 


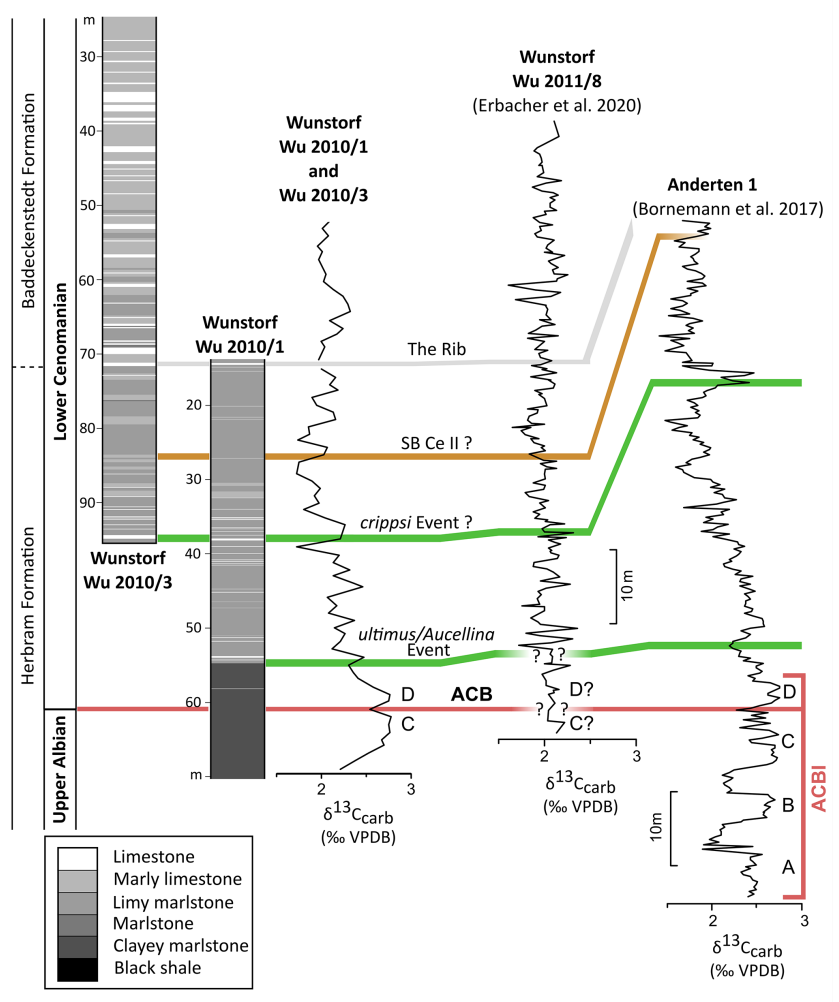

Figure 4. Correlated columnar sections of the Wunstorf cores $\mathrm{Wu}$ 2010/1 and Wu 2010/3 and their carbon isotope patterns. On the right correlation to the carbon isotopes of the Wunstorf Wu2011/8 core of Erbacher et al. (2020: Fig. 3) and to the Anderten-1 core of Bornemann et al. (2017: Fig. 3). Brown bar: correlation of a sequence boundary based on the isotopic pattern; green bar: correlation based on a bio-event; grey bar: correlation based on a lithoevent.

structures occur in the Wunstorf Wu2010/4 core (Seibertz, 2013; Fig. 5).

\subsubsection{Baddeckenstedt}

The abandoned quarry of Baddeckenstedt with WGS84 coordinates $52.091128^{\circ} \mathrm{N}, 10.229590^{\circ} \mathrm{E}$ is situated at the northern border of the Innerste Syncline and is part of the westerly Subhercynian Basin (Fig. 1). The outcrop shows a sequence of marl-limestone alternations of early and middle Cenomanian age and limestones of late Cenomanian to middle Turonian age. It contains ca. $24 \mathrm{~m}$ marl-limestone alternations of the Baddeckenstedt Formation (0-24 m) and $17.50 \mathrm{~m}$ limestones of the Brochterbeck Formation (24-41.50 m). The overlying Hesseltal and Söhlde formations are not considered in this study. A detailed framework is provided by Badaye (1986), Ernst and Rehfeld (1997, 1998), and Wilmsen and Niebuhr (2002), and a correlation to other Lower Saxonian outcrops is given by Wilmsen $(2003,2007)$.

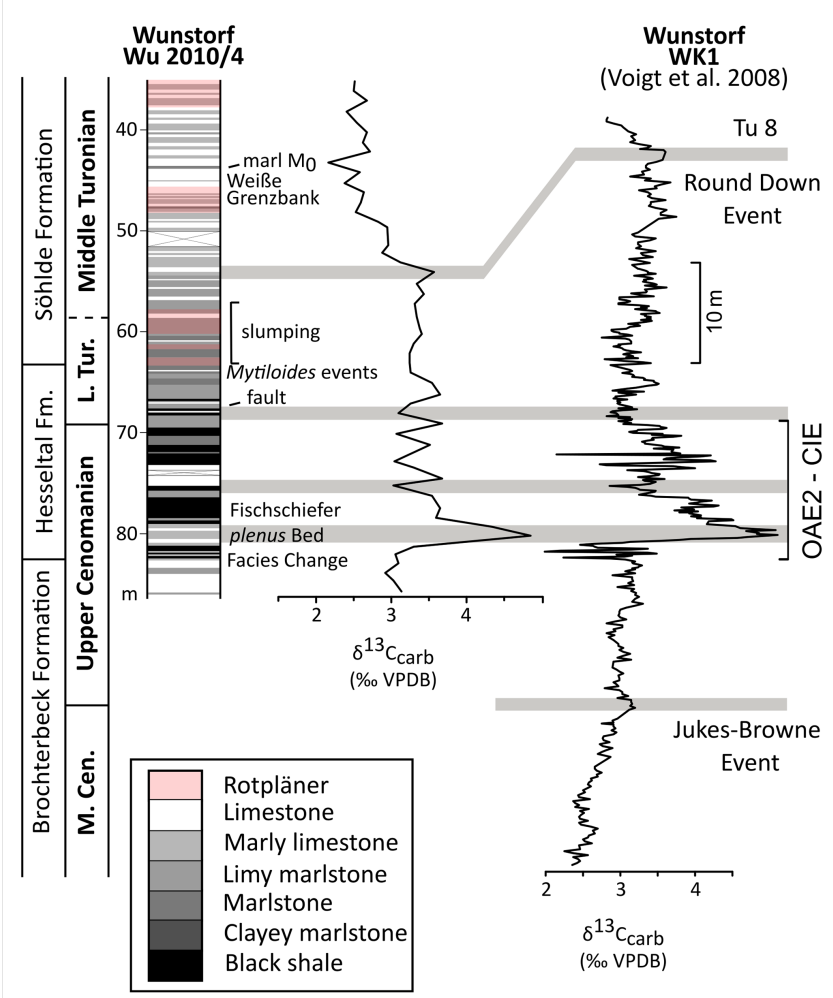

Figure 5. Columnar section of the Wunstorf core Wu 2010/4 and its carbon isotope patterns. Correlations to the Wunstorf WK1 core of Voigt et al. (2008b: Fig. 2) are based on the isotopic patterns and the thicknesses of strata. Grey bars: correlation of carbon isotope patterns.

\subsubsection{Söhlde}

The Söhlde-Loges quarry yields around $40 \mathrm{~m}$ of the uppermost Cenomanian to the upper Turonian limestones. The stratigraphic succession contains about $1 \mathrm{~m}$ limestones of the Brochterbeck Formation $(-1-0 \mathrm{~m}), 34 \mathrm{~m}$ limestones of the Söhlde Formation (0-34 m), and $3 \mathrm{~m}$ limestones of the Salder Formation (34-37 m). The quarry lies within the Lesse Syncline with WGS84 coordinates $52.186238^{\circ} \mathrm{N}, 10.247489^{\circ} \mathrm{E}$ and is thus part of the westerly Subhercynian Basin (Fig. 1). Detailed stratigraphic information is given in Ernst and Wood (1995, 1997), Voigt and Hilbrecht (1997), Ernst et al. (1998), and Wiese (2009).

\subsection{Sequence stratigraphical framework}

Several sequence stratigraphic investigations provided a detailed stratigraphical framework for the Cretaceous deposits of Lower Saxony (e.g. Wilmsen, 2003; Janetschke et al., 2015). Based on the sequence stratigraphical analysis by Ernst et al. (1996) and Robaszynski et al. (1998), depositional sequences are bounded by unconformities called sequence boundaries (SB; Fig. 3). 
Five Cenomanian depositional sequences (DSs) are noted at Baddeckenstedt and Wunstorf: DS Al-Ce 1 and DS Ce 25; the Turonian strata of Söhlde and Wunstorf mentioned in this study yield three complete depositional sequences: DS Ce-Tu 1 and DS Tu 2-3 (Fig. 3).

\section{Material and methods}

The Wunstorf cores were sampled in around $5 \mathrm{~m}$ intervals, and the Baddeckenstedt and Söhlde-Loges section were sampled in about $3 \mathrm{~m}$ intervals. Most of the 40 samples from Wunstorf and 31 samples from Baddeckenstedt and Söhlde consist of limestones or marly limestones. Samples from the black shale-marlstone interval around the CenomanianTuronian boundary at Wunstorf were collected from marly limestones between the bituminous layers. Samples of about $100 \mathrm{~g}$ were treated with formic acid $\left(\mathrm{CH}_{2} \mathrm{O}_{2}\right)$ for about $24 \mathrm{~h}$ at $20^{\circ} \mathrm{C}$. After the complete dissolution of carbonate, the residue was washed carefully within a $63 \mu \mathrm{m}$ sieve to remove all clay particles from it. This method enables studies of the agglutinated foraminiferal fauna in compacted and highly lithified limestones, which were previously not studied (Frieg and Kemper, 1989). The taxonomy is mainly based on Loeblich and Tappan (1987), Frieg (1980), Frieg and Kemper (1989), Kaminski and Gradstein (2005), Kaminski et al. (2011), and Setoyama et al. (2017). The classification scheme for agglutinated foraminifers of Kaminski (2014) was applied. At least 300 specimens from each sample were counted; indeterminable specimens were not counted. As far as possible, specimens were taxonomically assigned at the species level, as generic information does not seem to be fully reliable for biodiversity data analyses (Wiese et al., 2016). Tubular agglutinated foraminifers are usually preserved highly fragmented. The minimum fragmentation factor is 5 (Bubík, 2019). Thus, tubular specimen counts were divided by the factor 5 , to reduce the impact of tubular foraminifera on the relative abundances. They are displayed as "calculated specimens" in Sect. 5. Abundances based on relative abundances are given as follows: very abundant $(>15 \%)$, abundant $(15 \%-5 \%)$, common $(5 \%-2 \%)$, rare $(2 \%-1 \%)$, and very rare $(<1 \%)$. For diversity analysis, the Fisher alpha index (Fisher et al., 1943) was calculated with PAST (version 3.26; Hammer et al., 2001), and the total species richness (number of taxa) was calculated. High Fisher alpha index and species richness reflect highly diverse assemblages, while low values correspond to lowdiversity foraminiferal assemblages. Morphogroup analysis is based on the idea that different groups of agglutinated foraminifera can be divided by their morphology, which differs due to preferred habitats and thus different factors such as mainly feeding strategies. Relative abundances of different morphogroups can be linked to environmental changes interpreted based on modern foraminiferal studies (Jones and Charnock, 1985; Jorissen et al., 1995; Van der Zwaan et al., 1999; Murray et al., 2011). The scheme used in this study (see Table 1) is modified for Cretaceous agglutinated foraminiferal assemblages after Frenzel (2000), Cetean et al. (2011), and Setoyama et al. (2017). All photographs were taken on a Keyence VHX-1000 digital microscope multiscan at Freie Universität, Berlin, Section Palaeontology.

The bulk-carbonate carbon isotope measurements of samples of the Wunstorf cores Wu2010/1, Wu2010/3, and Wu2010/4 were conducted at the Museum für Naturkunde, Berlin, using a GasBench II linked to a Thermo Fisher Scientific DeltaV isotope ratio mass spectrometer. All values are given in per mil (\%o) versus VPDB. The analytical precision of repeated in-house standard material (limestone) is generally better than $\pm 0.1 \%$.

\section{Systematics}

The classification for agglutinated foraminifers of Kaminski (2010) was used for the taxa recorded from the Wunstorf cores, Baddeckenstedt, and Söhlde sections. A total of 14522 specimens of 90 species and taxa of a higher level of Wunstorf were determined, and 10406 specimens consisting of 105 taxa of samples from the Baddeckenstedt and Söhlde sections were determined. Hereinafter mentioned literature contains first descriptions of taxa and information for identification used.

\section{Class Foraminifera d'Orbigny 1826}

Subclass Monothalamana Pawlowski, Holzmann and Tyszka 2013

Order Astrorhizida Lankester 1885

Suborder Astrorhizina Lankester 1885

Superfamily Astrorhizoidea Brady 1881

Family Astrorhizidae Brady 1881

Genus Astrorhiza Sandahl 1858

Astrorhiza sp.

\section{Material}

One specimen from the Baddeckenstedt section.

\section{Occurrence}

Very rare.

Family Rhabdamminidae Brady 1884

Subfamily Rhabdammininae Brady 1884

Genus Rhabdammina Sars in Carpenter 1869

Rhabdammina sp. 
Table 1. Agglutinated foraminiferal morphogroups, morphotypes/test forms, and life environments modified after Frenzel (2000), Cetean et al. (2011), and Setoyama et al. (2017) correlated to main genera treated in this study.

\begin{tabular}{|c|c|c|c|c|}
\hline Morphogroup & Test form & Life position & Environment & Main genera \\
\hline M1 & Tubular & Erect epifauna & bathyal and abyssal & $\begin{array}{l}\text { Bathysiphon, } \\
\text { Nothia, } \\
\text { Psammosiphonella }\end{array}$ \\
\hline M2a & Globular & Shallow infaunal & bathyal and abyssal & $\begin{array}{l}\text { Caudammina, } \\
\text { Psammosphaera, } \\
\text { Saccammina }\end{array}$ \\
\hline $\mathrm{M} 2 \mathrm{~b}$ & $\begin{array}{l}\text { Rounded trocho- and } \\
\text { streptospiral, } \\
\text { planoconvex } \\
\text { trochospiral }\end{array}$ & Surficial epifaunal & Shelf to deep marine & $\begin{array}{l}\text { Ataxophragmium, } \\
\text { Trochammina }\end{array}$ \\
\hline M2c & Elongate keeled & Surficial epifaunal & Shelf to marginal marine & Spiroplectammina \\
\hline M3a & $\begin{array}{l}\text { Flattened planispiral } \\
\text { and streptospiral }\end{array}$ & Surficial epifaunal & Lagoonal to abyssal & $\begin{array}{l}\text { Ammodiscus, } \\
\text { Glomospira, } \\
\text { Repmanina }\end{array}$ \\
\hline M3b & Flattened irregular & Surficial epifaunal & Upper bathyal to abyssal & Ammolagena \\
\hline M3c & Flattened streptospiral & Surficial epifaunal & Upper bathyal to abyssal & $\begin{array}{l}\text { Ammosphaeroidina, } \\
\text { Praecystammina, } \\
\text { Trochamminoides }\end{array}$ \\
\hline M4a & Rounded planispiral & $\begin{array}{l}\text { Surficial epifaunal } \\
\text { and/or shallow infaunal }\end{array}$ & Inner shelf to upper bathyal & Haplophragmoides \\
\hline \multirow[t]{2}{*}{ M4b } & Elongate subcylindrical & Deep infaunal & Inner shelf to upper bathyal & $\begin{array}{l}\text { Arenobulimina, } \\
\text { Gerochammina, } \\
\text { Tritaxia }\end{array}$ \\
\hline & Elongate tapered & Deep infaunal & Inner shelf to upper bathyal & $\begin{array}{l}\text { Ammobaculites, } \\
\text { Bulbobaculites, } \\
\text { Pseudonodosinella }\end{array}$ \\
\hline
\end{tabular}

\section{Material}

A total of 10 specimens from the Baddeckenstedt section and 15 specimens from the Söhlde section.

\section{Occurrence}

Very rare.

Subfamily Bathysiphoninae Avnimelech 1952

Genus Bathysiphon Sars 1872

Bathysiphon spp.

\section{Material}

A total of 118 calculated specimens from the Baddeckenstedt section, 131 specimens from the Söhlde section, 235 specimens from the Wunstorf Wu2010/1 core, 176 specimens from the Wunstorf Wu2010/3 core, and 112 specimens from the Wunstorf Wu2010/4 core.

\section{Occurrence}

Abundant in the uppermost Albian to lowermost Cenomanian at Wunstorf and common to rare in the Cenomanian to Turonian of Lower Saxony.

Genus Nothia Pflaumann 1964

Nothia spp.

\section{Material}

A total of 68 calculated specimens from the Baddeckenstedt section, 15 specimens from the Söhlde section, 235 specimens from the Wunstorf Wu2010/1 core, 70 specimens from the Wunstorf Wu2010/3 core, and 31 specimens from the Wunstorf Wu2010/4 core.

\section{Occurrence}

Abundant in the uppermost Albian at Wunstorf, common to rare in the Cenomanian, and rare to very rare in the Turonian. 
Genus Psammosiphonella Avnimelich 1952

Psammosiphonella spp.

\section{Material}

A total of 99 calculated specimens from the Baddeckenstedt section, 125 specimens from the Söhlde section, 100 specimens from the Wunstorf Wu2010/1 core, 65 specimens from the Wunstorf Wu2010/3 core, and 68 specimens from the Wunstorf Wu2010/4 core.

\section{Occurrence}

Common to rare.

Order Saccamminina Lankester 1885

Suborder Hemisphaerammininae Loeblich and Tappan 1961, emend Mikhalevich 1995

Genus Hemisphaerammina Loeblich and Tappan 1957

Hemisphaerammina batalleri Loeblich and Tappan, 1957

1957. Hemisphaerammina batalleri, Loeblich and Tappan, p. 224 , pl. 72 , fig. 3 .

\section{Material}

Four specimens from the Baddeckenstedt section and six specimens from the Söhlde section.

\section{Occurrence}

Very rare.

Hemisphaerammina glandiformis Hercogová and Kriz 1983

1983. Hemisphaerammina glandiformis Hercogová and Kriz, p. 210, pl. 5, figs. 5a, b.

\section{Material}

Six specimens from the Baddeckenstedt section and one specimen from the Söhlde section.

\section{Occurrence}

Very rare.

Suborder Saccamminoidea Brady 1884

Family Saccamminidae Brady 1884

Subfamily Saccammininae Brady 1884

Genus Lagenammina Rhumbler 1911
Lagenammina difflugiformis (Brady, 1879)

1879. Reophax difflugiformis Brady, p. 51, pl. 4, fig. 3.

1990. Lagenammina difflugiformis (Brady); Charnock and Jones, p. 146, pl. 1, fig. 2, pl. 13, fig. 2 .

\section{Material}

A total of 17 specimens from the Baddeckenstedt section and two specimens from the Söhlde section.

\section{Occurrence}

Rare to very rare.

Genus Placentammina Thalmann 1947

Placentammina cf. placenta (Grzybowski, 1898)

1898. Reophax placenta Grzybowski, p. 276, pl. 10, figs. 910.

1990. Saccammina placenta (Grzybowski); Kuhnt, p. 325, pl. 2, fig. 1

1993. Saccammina placenta (Grzybowski); Kaminski and Geroch, p. 249, pl. 2, figs. 5-7.

2005. Placentammina placenta (Grzybowski); Kaminski and Gradstein, p. 136, pl. 11, figs. 1-6.

2011. Placentammina placenta (Grzybowski); Kaminski et al., p. 84, pl. 1, fig. 4 .

\section{Material}

A total of 8 specimens from the Baddeckenstedt section, 16 specimens from the Söhlde section, 26 specimens from the Wunstorf Wu2010/1 core, and 1 specimen from the Wunstorf Wu2010/3 core.

\section{Remarks}

This species is reported no earlier than Santonian (Kuhnt, 1990) but appears already in the uppermost Albian of the Wunstorf cores.

\section{Occurrence}

Common to rare in the uppermost Albian at Wunstorf, otherwise very rare.

Genus Saccammina Carpenter 1869

Saccammina grzybowskii (Schubert, 1902)

Fig. 6a

1902. Reophax grzybowskii Schubert, p. 20, pl. 1, figs. 13ab.

1993. Saccammina grzybowskii (Schubert); Kaminski and Geroch, p. 248, pl. 2, figs. 1a-4b. 
2005. Saccammina grzybowskii (Schubert); Kaminski and Gradstein, p. 132, pl. 10, figs. 1-9.

2011. Saccammina grzybowskii (Schubert); Kaminski et al., p. 84 , pl. 1 , fig. 5 .

\section{Material}

A total of 23 specimens from the Baddeckenstedt section, 81 specimens from the Söhlde section, 82 specimens from the Wunstorf Wu2010/1 core, 32 specimens from the Wunstorf Wu2010/3 core, and 55 specimens from the Wunstorf Wu2010/4 core.

\section{Occurrence}

Abundant to common in the uppermost Albian of Wunstorf and in the Turonian of Söhlde and rare to very rare in all other studied stratigraphical intervals.

Saccammina sphaerica Brady, 1871

1871. Saccammina sphaerica Brady, p. 183.

\section{Material}

Three specimens from the Söhlde section.

\section{Occurrence}

Very rare in the late Turonian.

Superfamily Psammosphaeroidea Haeckel 1894

Family Psammosphaeridae Haeckel 1894

Subfamily Psammosphaerinae Haeckel 1894

Genus Psammosphaera Schultze 1875

Psammosphaera fusca Schultze, 1875

Fig. 6b

1875. Psammosphaera fusca Schultze, p. 113, pl. 2, figs. 8af.

2005. Psammosphaera fusca Schultze; Kaminski and Gradstein, p. 125, pl. 8, figs. 1-9.

\section{Material}

A total of 14 specimens from the Baddeckenstedt section, 5 specimens from the Söhlde section, 129 specimens from the Wunstorf Wu2010/1 core, and 7 specimens from the Wunstorf Wu2010/3 core.

\section{Occurrence}

Abundant in the uppermost Albian to lowermost Cenomanian of Wunstorf, otherwise very rare.

Psammosphaera irregularis (Grzybowski, 1896)

1896. Keramosphaera irregularis Grzybowski, p. 273, pl. 8, figs. 12-13.

2005. Psammosphaera irregularis (Grzybowski); Kaminski and Gradstein, p. 131, pl. 9, figs. 1-9.

\section{Material}

A total of 64 specimens from the Baddeckenstedt section, 74 specimens from the Söhlde section, 30 specimens from the Wunstorf Wu2010/1 core, 3 specimens from the Wunstorf Wu2010/3 core, and 2 specimens from the Wunstorf Wu2010/4 core.

\section{Occurrence}

Common in the uppermost Albian at Wunstorf and Turonian at Söhlde, otherwise rare to very rare.

Subclass Tubothalama Pawlowski, Holzmann and Tyszka 2013

Order Ammodiscida Mikhalevich 1980

Suborder Hippocrepinina Saidova 1981

Superfamily Hippocrepinoidea Rhumbler 1895

Family Hippocrepinidae Rhumbler 1895

Subfamily Jaculellinae Mikhalevich 1995

Genus Kechenotiske Loeblich and Tappan 1984

Kechenotiske sp.

\section{Material}

Five specimens from the Baddeckenstedt section and one specimen from the Söhlde section.

\section{Occurrence}

Very rare.

Genus Tipeammina Neagu 2004

Tipeammina elliptica (Deeke, 1884)

Fig. 6c

1884. Rhabdammina elliptica Deeke, p. 23, pl. 1, figs. 1a, b. 2004. Tipeammina elliptica (Deeke); Neagu, pl. 1, figs. 10 12, fig. 2 . 


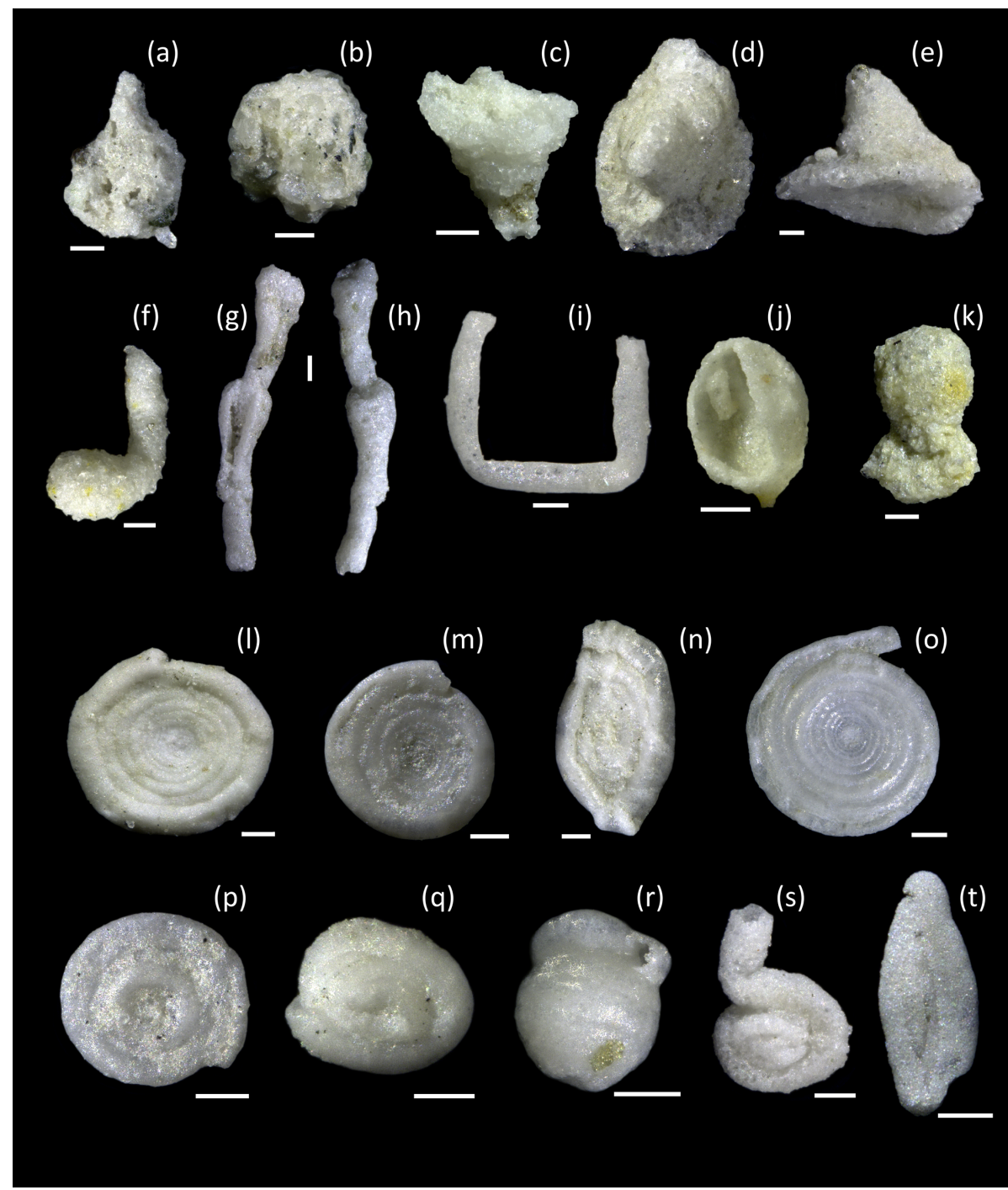

Figure 6. Late Albian to Turonian agglutinated foraminifera from the Lower Saxonian Cretaceous; scale bars are $100 \mu \mathrm{m}$. (a) Saccammina grzybowski, Wunstorf Wu2010/1, 54.00 m. (b) Psammosphaera fusca, Wunstorf Wu2010/1, 59.05 m. (c) Tipeammina elliptica, Söhlde section, 31.00 m. (d-e) Tipeammina sp. 1, Wunstorf Wu2010/4, 43.30 m. (f) Hyperammina gaultina, Wunstorf Wu 2010/4, 48.20 m. (g-h) Ammolagena clavata, two specimens sticking together, Wunstorf Wu2010/3, 25.50 m. (i) Ammolagena contorta, possibly previously attached on an inoceramid prism, Wunstorf Wu2010/4, 38.20 m. (j) Caudammina ovula, Söhlde section, 31.00 m. (k) Subreophax scalaris, Wunstorf Wu2010/1, 69.10 m. (l) Ammodiscus cretaceus, Wunstorf Wu 2010/4, 48.20 m. (m) Ammodiscus glabratus, Wunstorf Wu2010/1, 54.65 m. (n) Ammodiscus peruvianus, Wunstorf Wu2010/1, 54.00 m. (o) Ammodiscus tenuissimus, Wunstorf Wu2010/4, 43.30 m. (p) Glomospira diffundens, Wunstorf Wu2010/1, 49.05 m. (q) Glomospira gordialis, Wunstorf Wu 2010/3, 66.05 m. (r) Repmanina charoides, Wunstorf Wu2010/4, 38.20 m. (s) Lituotuba lituiformis, Wunstorf Wu 2010/4, 48.95 m. (t) Rzehakina minima, Wunstorf Wu2010/1, 54.80 m.

\section{Material}

A total of 3 specimens from the Baddeckenstedt section and 15 specimens from the Söhlde section.

\section{Occurrence}

Rare to very rare in the Turonian at Söhlde, otherwise very rare.

\section{Tipeammina sp. 1}

Fig. 6d-e

\section{Remarks}

Test free, bilocular. Coarsely agglutinated, thick test. Aperture at the end of the tube as simple opening. Initial chamber is mostly not preserved, second chamber growing rapidly in diameter. Differs from Tipeammina elliptica in its much faster growth in diameter. 


\section{Material}

A total of 18 specimens from the Baddeckenstedt section, 38 specimens from the Söhlde section, 2 specimens from the Wunstorf Wu2010/1 core, 3 specimens from the Wunstorf Wu2010/3 core, and 29 specimens from the Wunstorf Wu2010/4 core.

\section{Occurrence}

Rare to very rare.

Family Hyperamminidae Eimer and Fickert 1899

Subfamily Hyperammininae Eimer and Fickert 1899

Genus Hyperammina Brady 1878

Hyperammina gaultina Ten Dam, 1950

Fig. $6 f$

1950. Hyperammina gaultina Ten Dam, p. 5, pl. 1, fig. 2.

\section{Material}

A total of 4 specimens from the Baddeckenstedt section, 19 specimens from the Wunstorf Wu2010/1 core, and 1 specimen from the Wunstorf Wu2010/4 core.

\section{Occurrence}

Common in the uppermost Albian at Wunstorf, otherwise very rare.

\section{Hyperammina sp.}

\section{Material}

Six specimens from the Söhlde section.

\section{Occurrence}

Very rare.

Superfamily Hormosinelloidea Rauser and Reitlinger 1986

Family Ammolagenidae Kaminski, Henderson, Cetean and Waśkowska 2009

Genus Ammolagena Eimer and Fickert 1899

Ammolagena clavata (Jones and Parker, 1860)

Fig. $6 \mathrm{~g}-\mathrm{h}$

1860. Trochammina irregularis (d'Orbigny) var. clavat Jones and Parker; Carpenter et al., p. 142, pl. 11, fig. 6.
1987. Ammolagena clavata (Jones \& Parker); Loeblich and Tappan, p. 49, pl. 36, fig. 16.

2005. Ammolagena clavata (Jones \& Parker); Kaminski and Gradstein, pp. 165-168, pl. 21, fig. 21.

\section{Material}

A total of 141 specimens from the Baddeckenstedt section, 28 specimens from the Söhlde section, 100 specimens from the Wunstorf Wu2010/1 core, 154 specimens from the Wunstorf Wu2010/3 core, and 15 specimens from the Wunstorf $\mathrm{Wu} 2010 / 4$ core.

\section{Remarks}

This species usually occurs only in diverse agglutinated foraminiferal assemblages and can be used as an indicator for a low supply of clastic material (Waśkowska, 2014).

\section{Occurrence}

Abundant to common in the Cenomanian and rare to very rare in the Turonian.

Ammolagena contorta Waters, 1927

Fig. 6i

1927. Ammolagena contorta Waters, p. 132, pl. 22, fig. 4. 2017. Ammolagena contorta Waters; Setoyama et al., p. 211, pl. 1, fig. 2.

\section{Materia}

A total of 181 specimens from the Baddeckenstedt section, 664 specimens from the Söhlde section, 44 specimens from the Wunstorf Wu2010/1 core, 64 specimens from the Wunstorf Wu2010/3 core, and 125 specimens from the Wunstorf Wu2010/4 core.

\section{Remarks}

Ammolagena contorta was reported from the Upper Cretaceous of the Arctic realm (Setoyama et al., 2011, 2017). A preference of colder temperate environments of this species is therefore likely.

\section{Occurrence}

Common to rare in the Cenomanian, abundant to common in the Turonian at Wunstorf, and very abundant to abundant in the Turonian at Söhlde.

Family Hormosinellidae Rauser and Reitlinger 1986

Genus Caudammina Montanaro-Gallitelli 1955

Caudammina cf. excelsa (Dylążanka, 1923) 
1923. Hyperammina excelsa Dylążanka, p. 66, pl. 1, fig. 3. 1993. Hormosina excelsa (Dylążanka); Kaminski and Geroch, p. 281, pl. 17, figs. 1-4b.

2005. Caudammina excelsa (Dylążanka); Kaminski and Gradstein, p. 230, pl. 40, figs. 1a-5.

2011. Caudammina excelsa (Dylążanka); Kaminski et al., p. 86 , pl. 2, fig. 1 .

\section{Material}

Five specimens from the Wunstorf Wu2010/1 core.

\section{Remarks}

The known stratigraphic range of this species spans from the Turonian to the Eocene (Kaminski and Gradstein, 2005), Weidich (1990) reported it from the Berriasian to the Cenomanian from the northern Calcareous Alps, while Kaminski et al. (1992) cited a similar form from the Lower Cretaceous of the Indian Ocean.

\section{Occurrence}

Very rare in the uppermost Albian and lowermost Cenomanian of Wunstorf.

Caudammina ovula (Grzybowski, 1896)

Fig. 6j

1896. Reophax ovulum Grzybowski, p. 276, pl. 8, figs. 1921.

1988. Hormosina ovulum ovulum (Grzybowski); Kaminski et al., p. 186, pl. 2, fig. 10.

2005. Caudammina ovula (Grzybowski); Kaminski and Gradstein, p. 233, pl. 41, figs. 1a-8.

2011. Caudammina ovula (Grzybowski); Kaminski et al., p. 86 , pl. 2 , fig. 3 .

\section{Material}

A total of 58 specimens from the Baddeckenstedt section, 63 specimens from the Söhlde section, 3 specimens from the Wunstorf Wu2010/1 core, 4 specimens from the Wunstorf Wu2010/3 core, and 15 specimens from the Wunstorf $\mathrm{Wu} 2010 / 4$ core.

\section{Occurrence}

Very rare at Wunstorf and common to rare at Baddeckenstedt and Söhlde.

Caudammina ovuloides (Grzybowski, 1901)

1901. Reophax ovuloides Grzybowski, p. 233, pl. 8, fig. 3. 1988. Hormosina ovuloides (Grzybowski); Kaminski et al., p. 186, pl. 2, figs. 3-4.
2005. Caudammina ovuloides (Grzybowski); Kaminski and Gradstein, p. 238, pl. 42, figs. 1a-7.

\section{Material}

Five specimens from the Baddeckenstedt section, nine specimens from the Wunstorf Wu2010/1 core, and four specimens from the Wunstorf Wu2010/3 core.

\section{Occurrence}

Very rare in the Cenomanian.

Caudammina sp.

\section{Material}

In total 24 specimens from the Söhlde section.

\section{Occurrence}

Very rare.

Genus Hormosinella Stschedrina 1969

Hormosinella fusiformis Kaminski, Cetean, Balc and Coccioni 2011

2011. Hormosinella fusiformis Kaminski, Cetean, Balc and Coccioni, p. 87, pl. 2, figs. 6-12.

\section{Material}

In total, 11 specimens from the Baddeckenstedt section.

\section{Occurrence}

Very rare in the lower Cenomanian of the Baddeckenstedt section.

Genus Subreophax Saidova 1975

Subreophax scalaris (Grzybowski, 1896)

Fig. 6k

1896. Reophax guttifera (Brady) var scalaria Grzybowski, p. 277 , pl. 8 , figs. 26a-b.

1988. Subreophax scalaris (Grzybowski); Kaminski et al., p. 187, pl. 2, figs. 16-17.

2005. Subreophax scalaris (Grzybowski); Kaminski and Gradstein, p. 278, pl. 55, figs 1-7.

2011. Subreophax scalaris (Grzybowski); Kaminski et al., p. 87 , pl. 3 , fig. 7 .

\section{Material}

A total of 3 specimens from the Baddeckenstedt section, 41 specimens from the Wunstorf Wu2010/1 core, and 6 specimens from the Wunstorf Wu2010/3 core. 


\section{Occurrence}

Common in the uppermost Albian of the Wunstorf cores and very rare in the Cenomanian.

Suborder Ammodiscina Mikhalevich 1980

Superfamily Ammodiscoidea Reuss 1862

Family Ammodiscidae Reuss 1862

Subfamily Ammodiscinae Reuss 1862

Genus Agathamminoides Vangerow 1964

Agathamminoides serpens (Grzybowski, 1898)

1898. Ammodiscus serpens Grzybowski, p. 285, pl. 10, fig. 31 (not figs. 32 and 33).

1993. Glomospira serpens (Grzybowski); Kaminski and Geroch, p. 256, pl. 6, figs. 2-5.

2005. "Glomospira” serpens (Grzybowski); Kaminski and Gradstein, p. 189, pl. 27, figs. 1a-6b.

2021. Agathamminoides serpens (Grzybowski); Kaminski et al., p. 347, pl. 2, fig. 11 .

\section{Material}

A total of 2 specimens from the Baddeckenstedt section, 5 specimens from the Söhlde section, 14 specimens from the Wunstorf Wu2010/1 core, 12 specimens from the Wunstorf Wu2010/3 core, and 2 specimens from the Wunstorf Wu2010/4 core.

\section{Occurrence}

Very rare.

Genus Ammodiscus Reuss 1862

Ammodiscus cretaceus (Reuss, 1845)

Fig. 61

1845. Operculina cretacea Reuss, p. 35, pl. 13, figs 64-65. 1934. Ammodiscus cretacea (Reuss); Cushman, p. 608, pl. 21, figs. 3a-b.

1990. Ammodiscus cretaceus (Reuss); Kuhnt, p. 310, pl. 1, figs. 2-3.

2005. Ammodiscus cretaceus (Reuss); Kaminski and Gradstein, p. 145, pl. 14, figs 1a-10.

2011. Ammodiscus cretaceus (Reuss); Kaminski et al., p. 84, pl. 1, fig. 9 .

\section{Material}

A total of 107 specimens from the Baddeckenstedt section, 100 specimens from the Söhlde section, 52 specimens from the Wunstorf Wu2010/1 core, 88 specimens from the Wunstorf Wu2010/3 core, and 159 specimens from the Wunstorf $\mathrm{Wu} 2010 / 4$ core.

\section{Occurrence}

Common to very rare.

Ammodiscus glabratus Cushman and Jarvis, 1928

Fig. 6m

1928. Ammodiscus glabratus Cushman and Jarvis, p. 87, pl. 12, fig. 6a, b.

2005. Ammodiscus glabratus Cushman and Jarvis; Kaminski and Gradstein, p.148, pl. 15, figs. 1a-6.

2011. Ammodiscus glabratus Cushman and Jarvis; Kaminski et al., p. 85, pl. 1, fig. 10.

\section{Material}

A total of 45 specimens from the Baddeckenstedt section, 85 specimens from the Söhlde section, 42 specimens from the Wunstorf Wu2010/1 core, 71 specimens from the Wunstorf Wu2010/3 core, and 166 specimens from the Wunstorf Wu2010/4 core

\section{Occurrence}

Common to very rare.

Ammodiscus peruvianus Berry, 1928

Fig. 6n

1928. Ammodiscus peruvianus Berry, p. 392, fig. 27.

2005. Ammodiscus peruvianus Berry; Kaminski and Gradstein, p. 157 , pl. 18, figs. 1a-6.

2011. Ammodiscus peruvianus Berry; Kaminski et al., p. 85, pl. 1, figs. 11-12.

\section{Material}

A total of 18 specimens from the Baddeckenstedt section, 32 specimens from the Söhlde section, 46 specimens from the Wunstorf Wu2010/1 core, 42 specimens from the Wunstorf Wu2010/3 core, and 94 specimens from the Wunstorf Wu2010/4 core.

\section{Occurrence}

Common to rare in the Turonian, otherwise very rare.

Ammodiscus tenuissimus Grzybowski, 1898

Fig. 60 
1898. Ammodiscus tenuissimus Grzybowski, p. 282, pl. 10, fig. 35 .

2005. Ammodiscus tenuissimus Grzybowski; Kaminski and Gradstein, p. 163, pl. 20, figs. 1a-7.

\section{Material}

A total of 15 specimens from the Baddeckenstedt section, 16 specimens from the Söhlde section, 71 specimens from the Wunstorf Wu2010/1 core, 61 specimens from the Wunstorf Wu2010/3 core, and 124 specimens from the Wunstorf Wu2010/4 core.

\section{Occurrence}

Abundant to common in the Cenomanian-Turonian boundary interval at Wunstorf, rare to very rare in other stratigraphical intervals, and very rare at Baddeckenstedt and Söhlde.

\section{Ammodiscus spp.}

\section{Material}

A total of 15 specimens from the Wunstorf Wu2010/1 core, 36 specimens from the Wunstorf Wu2010/3 core, and 43 specimens from the Wunstorf Wu2010/4 core.

\section{Occurrence}

Rare to very rare.

Genus Dolgenia Kemper 1995

Dolgenia pennyi (Cushman and Jarvis, 1928)

1928. Ammodiscus pennyi Cushman and Jarvis, p. 87, pl. 12, figs. 4-5.

2005. Ammodiscus pennyi Cushman and Jarvis; Kaminski and Gradstein, p. 155, pl. 17, figs. 1-6.

2008. Dolgenia pennyi (Cushman and Jarvis); Dolg et al., 2011, p. 271, pl. 3, figs. 12a-b.

2011. Dolgenia pennyi (Cushman and Jarvis); Kaminski et al., p. 85, pl. 1, fig. 13 .

\section{Material}

A total of 6 specimens from the Baddeckenstedt section, 33 specimens from the Söhlde section, 30 specimens from the Wunstorf Wu2010/1 core, 31 specimens from the Wunstorf Wu2010/3 core, and 28 specimens from the Wunstorf Wu2010/4 core.

\section{Occurrence}

Rare to very rare.

Subfamily Tolypammininae Cushman 1928
Genus Tolypammina Rhumbler 1895

Tolypammina sp.

\section{Material}

A total of 15 calculated specimens from the Baddeckenstedt section, 8 specimens from the Söhlde section, 40 specimens from the Wunstorf Wu2010/1 core, 42 specimens from the Wunstorf Wu2010/3 core, and 53 specimens from the Wunstorf Wu2010/4 core.

\section{Occurrence}

Rare to very rare.

$$
\begin{aligned}
& \text { Subfamily Usbekistaniinae Vialov } 1968 \\
& \text { Genus Glomospira Rzehak } 1885 \\
& \text { Glomospira diffundens Cushman and Renz, } 1946
\end{aligned}
$$

Fig. 6p

1946. Glomospira gordialis (Jones and Parker) var. diffundens Cushman and Renz, p. 15, pl. 1, fig. 30.

1984. Glomospira gordialis diffundens Cushman and Renz.; Hemleben and Troester, p. 519, pl. 1, fig. 21.

2005. Glomospira diffundens Cushman and Renz; Kaminski and Gradstein, p. 175, pl. 23, figs. 1-9.

\section{Material}

A total of 9 specimens from the Baddeckenstedt section, 9 specimens from the Söhlde section, 48 specimens from the Wunstorf Wu2010/1 core, 66 specimens from the Wunstorf Wu2010/3 core, and 55 specimens from the Wunstorf Wu2010/4 core.

\section{Occurrence}

Common to very rare at Wunstorf and very rare at Baddeckenstedt and at Söhlde.

Glomospira gordialis (Jones and Parker, 1860)

Fig. 6q

1860. Trochammina squamata (Jones and Parker) var. gordialis Jones and Parker, p. 292-307 (no type-figure given). 1990. Glomospira gordialis (Jones and Parker); Berggren and Kaminski, p. 73, pl. 1, fig. 1.

2005. Glomospira gordialis (Jones and Parker); Kaminski and Gradstein, p. 181, pl. 25, figs. 1-8.

2011. Glomospira gordialis (Jones and Parker); Kaminski et al., p. 85, pl. 1, fig. 14 . 


\section{Material}

A total of 57 specimens from the Baddeckenstedt section, 71 specimens from the Söhlde section, 40 specimens from the Wunstorf Wu2010/1 core, 67 specimens from the Wunstorf Wu2010/3 core, and 97 specimens from the Wunstorf Wu2010/4 core.

\section{Occurrence}

Common to very rare.

"Glomospira” irregularis (Grzybowski, 1898)

1898. Ammodiscus irregularis Grzybowski, p. 285, pl. 11, figs. $2,3$.

1984. Glomospira? irregularis (Grzybowski); Hemleben and Troester, p. 519, pl. 1, fig. 22.

1993. Glomospira irregularis (Grzybowski); Kaminski and Geroch, p. 256, pl. 6, figs. 6-8b.

2005. "Glomospira” irregularis (Grzybowski); Kaminski and Gradstein, p. 185, pl. 26, figs. 1a-7.

2011. "Glomospira" irregularis (Grzybowski); Kaminski et al., p. 85, pl. 1, fig. 15 .

\section{Material}

A total of 14 specimens from the Baddeckenstedt section, 39 specimens from the Söhlde section, 47 specimens from the Wunstorf Wu2010/1 core, 76 specimens from the Wunstorf Wu2010/3 core, and 34 specimens from the Wunstorf Wu2010/4 core.

\section{Occurrence}

Common to rare in the Cenomanian at Wunstorf, otherwise rare to very rare.

\section{Glomospira spp.}

\section{Material}

A total of 6 specimens from the Wunstorf Wu2010/1 core, 40 specimens from the Wunstorf Wu2010/3 core, and 48 specimens from the Wunstorf Wu2010/4 core.

\section{Occurrence}

Rare to very rare.

Genus Repmanina Suleymanov, In Arapova and Suleymanov 1966

Repmanina charoides (Jones and Parker, 1860)

Fig. 6r
1860. Trochammina squamata var. charoides Jones and Parker, p. 304.

1990. Glomospira charoides (Jones and Parker); Berggen and Kaminski, p. 60, pl. 1, fig. 2.

2001. Repmanina charoides (Jones and Parker); Alegret and Thomas, p. 300, pl. 10, fig. 11.

2011. Repmanina charoides (Jones and Parker); Kaminski et al., p. 86, pl. 1, figs. 17a-b.

2017. Repmanina charoides (Jones and Parker); Setoyama et al., p. 194, pl. 1, figs. 11-12.

\section{Material}

A total of 85 specimens from the Baddeckenstedt section, 164 specimens from the Söhlde section, 29 specimens from the Wunstorf Wu2010/1 core, 61 specimens from the Wunstorf Wu2010/3 core, and 262 specimens from the Wunstorf $\mathrm{Wu} 2010 / 4$ core.

\section{Occurrence}

Common to very rare in the Cenomanian and abundant to common in the Turonian.

Family Lituotubidae Loeblich and Tappan 1984

Genus Lituotuba Rhumbler 1895

Lituotuba lituiformis (Brady 1879)

Fig. 6s

1879. Trochammina lituiformis Brady, p. 59, pl. 5, fig. 16. 1990. Lituotuba lituiformis (Brady); Kuhnt, p. 318, pl. 1, figs. 17, 18.

2005. Lituotuba lituiformis (Brady); Kaminski and Gradstein, p. 287, pl. 38, figs. 1-8.

2011. Lituotuba lituiformis (Brady); Kaminski et al., p. 88, pl. 3, fig. 12.

\section{Material}

A total of 19 specimens from the Baddeckenstedt section, 31 specimens from the Söhlde section, 9 specimens from the Wunstorf Wu2010/1 core, 11 specimens from the Wunstorf Wu2010/3 core, and 48 specimens from the Wunstorf Wu2010/4 core.

\section{Occurrence}

Rare to very rare.

Family Trochamminoidae Haynes and Nwabufo-Ene 1998

Genus Trochamminoides Cushman 1910

Trochamminoides spp. 


\section{Material}

A total of 132 specimens from the Baddeckenstedt section, 125 specimens from the Söhlde section, 23 specimens from the Wunstorf Wu2010/1 core, 36 specimens from the Wunstorf Wu2010/3 core, and 69 specimens from the Wunstorf Wu2010/4 core.

\section{Occurrence}

Common.

Suborder Schlumbergerinina Mikhalevich 1980

Superfamily Rzehakinoidea Cushman 1933

Family Rzehakinidae Cushman 1933

Subfamily Rzehakininae Cushman 1933

Genus Rzehakina Cushman 1927

Rzehakina minima Cushman and Renz, 1946

Fig. 6t

1946. Rzehakina epigona (Rzehak) var. minima Cushman and Renz, p. 24, pl. 3, fig. 5.

2005. Rzehakina minima Cushman and Renz; Kaminski and Gradstein, p. 215, pl. 35, figs. 1a-10.

2011. Rzehakina minima Cushman and Renz; Kaminski et al., p. 86, pl. 1, fig. 19.

\section{Material}

A total of 2 specimens from the Baddeckenstedt section, 1 specimen from the Söhlde section, and 15 specimens from the Wunstorf Wu2010/1 core.

\section{Occurrence}

Very rare in the uppermost Albian to the upper Cenomanian of Lower Saxony.

Subclass Globothalama Pawlowski, Holzmann and Tyszka 2013

Order Lituolida Lankester 1885

Suborder Hormosinina Mikhalevich 1980

Superfamily Hormosinoidea Haeckel 1894

Family Aschemocellidae, Vialov 1966

Genus Kalamopsis De Folin 1883

Kalamopsis grzybowskii (Dylążanka, 1923)

1923. Hyperammina grzybowskii Dylążanka, 1923, p. 65.
1995. Kalamopsis grzybowskii (Dylążanka); Bubík, pl. 9 fig. 5.

2017. Kalamopsis grzybowskii (Dylążanka); Setoyama et al., p. 191, pl. 1, fig. 18 .

\section{Material}

One specimen from the Baddeckenstedt section.

\section{Occurrence}

Very rare in the middle Cenomanian of Baddeckenstedt.

Family Reophacidae Cushman 1927

Genus Hormosinelloides Zheng 2001

Hormosinelloides guttifer (Brady, 1884)

1884. Reophax guttifera Brady, p. 278.

2011. Hormosinelloides guttifer (Brady); Kaminski, p. 87 pl. 2, fig. 13 .

\section{Material}

Five specimens from the Baddeckenstedt section, one specimen from the Wunstorf Wu2010/1 core, and one specimen from the Wunstorf Wu2010/4 core.

\section{Occurrence}

Very rare.

Genus Reophax De Montfort 1808

Reophax cf. globosus Sliter, 1968

1968. Reophax globosus Sliter, p. 43, pl. 1, fig. 12.

\section{Remarks}

The reported stratigraphic range of this species spans from the Campanian to the Paleocene (Kaminski and Gradstein, 2005). Beckmann (1994) described it from Cenomanian strata of Trinidad.

\section{Material}

In total 19 specimens from the Baddeckenstedt section.

\section{Occurrence}

Very rare in the lower to middle Cenomanian at Baddeckenstedt.

Reophax scorpiurus de Montfort, 1808

1808. Reophax scorpiurus de Montfort, p. 331.

1971. Reophax scorpiurus de Montfort; Fuchs, p. 9, pl. 1, fig. 3 . 


\section{Material}

Four specimens from the Baddeckenstedt section.

\section{Occurrence}

Very rare in the lower Cenomanian at Baddeckenstedt.

Reophax subfusiformis (Earland, 1933)

Fig. 6a

1933. Reophax subfusiformis Earland, p. 74, pl. 2, figs. 1619.

2005. Reophax subfusiformis (Earland); Kaminski and Gradstein, p. 275, pl. 54, figs. 1-8.

\section{Material}

A total of 13 specimens from the Baddeckenstedt section, 2 specimens from the Söhlde section, and 96 specimens from the Wunstorf Wu2010/1 core.

\section{Occurrence}

Abundant to common in the uppermost Albian and lowermost Cenomanian at Wunstorf, otherwise very rare.

Family Hormosinidae Haeckel 1894

Subfamily Hormosininae Haeckel 1894

Genus Pseudonodosinella Saidova 1970

Pseudonodosinella nodulosa (Brady, 1879)

Fig. $7 b$

1879. Reophax nodulosa Brady, p. 52, pl. 4, figs. 7-8.

2005. Pseudonodosinella nodulosa (Brady); Kaminski and Gradstein, p. 259, pl. 49, figs. 1-9.

2017. Pseudonodosinella nodulosa (Brady); Setoyama, p. 193, pl. 1, fig. 21.

\section{Material}

A total of 48 specimens from the Baddeckenstedt section, 72 specimens from the Söhlde section, 27 specimens from the Wunstorf Wu2010/3 core, and 84 specimens from the Wunstorf Wu2010/4 core.

\section{Occurrence}

First occurrence in the lower Cenomanian of Wunstorf above The Rib. Abundant to common in the upper Cenomanian at Baddeckenstedt and Söhlde and in the middle Turonian at Wunstorf, otherwise rare to very rare.
Pseudonodosinella parvula (Huss, 1966)

Fig. 7c

1966. Reophax parvulus Huss, p. 21, pl. 1, figs. 26-30.

1995. Pseudonodosinella parvula (Huss); Geroch and Kaminski, p. 118, pl. 2, figs. 1-19.

2011. Pseudonodosinella parvula (Huss); Kaminski et al., p. 88 , pl. 3, fig. 11 .

2017. Pseudonodosinella parvula (Huss); Setoyama et al., p. 193, pl. 1, fig. 22.

\section{Material}

A total of 9 specimens from the Baddeckenstedt section, 53 specimens from the Söhlde section, 15 specimens from the Wunstorf Wu2010/1 core, 19 specimens from the Wunstorf Wu2010/3 core, and 79 specimens from the Wunstorf Wu2010/4 core.

\section{Occurrence}

First occurrence in the lowermost Cenomanian of Wunstorf and common in the lowermost Turonian of Söhlde, otherwise rare to very rare.

\section{Pseudonodosinella troyeri (Tappan, 1960)}

Fig. 7d

1960. Reophax troyeri Tappan, p. 291, pl. 1, figs. 10-12. 1995. Pseudonodosinella troyeri (Tappan); Geroch and Kaminski, p. 118, pl. 1, figs. 1, 2, 4-17.

\section{Material}

A total of 35 specimens from the Baddeckenstedt section, 9 specimens from the Söhlde section, 20 specimens from the Wunstorf Wu2010/1 core, 24 specimens from the Wunstorf Wu2010/3 core, and 10 specimens from the Wunstorf Wu2010/4 core.

\section{Occurrence}

Common to very rare in the Cenomanian. Last occurrence in the uppermost Cenomanian at Söhlde and lowermost Turonian at Wunstorf.

Suborder Lituolina Lankester 1885

Superfamily Lituolidea Blainville 1827

Family Haplophragmoididae Maync 1952

Genus Haplophragmoides Cushman 1910

Haplophragmoides aff. bubiki Setoyama, Kaminski and Tyszka 2008 


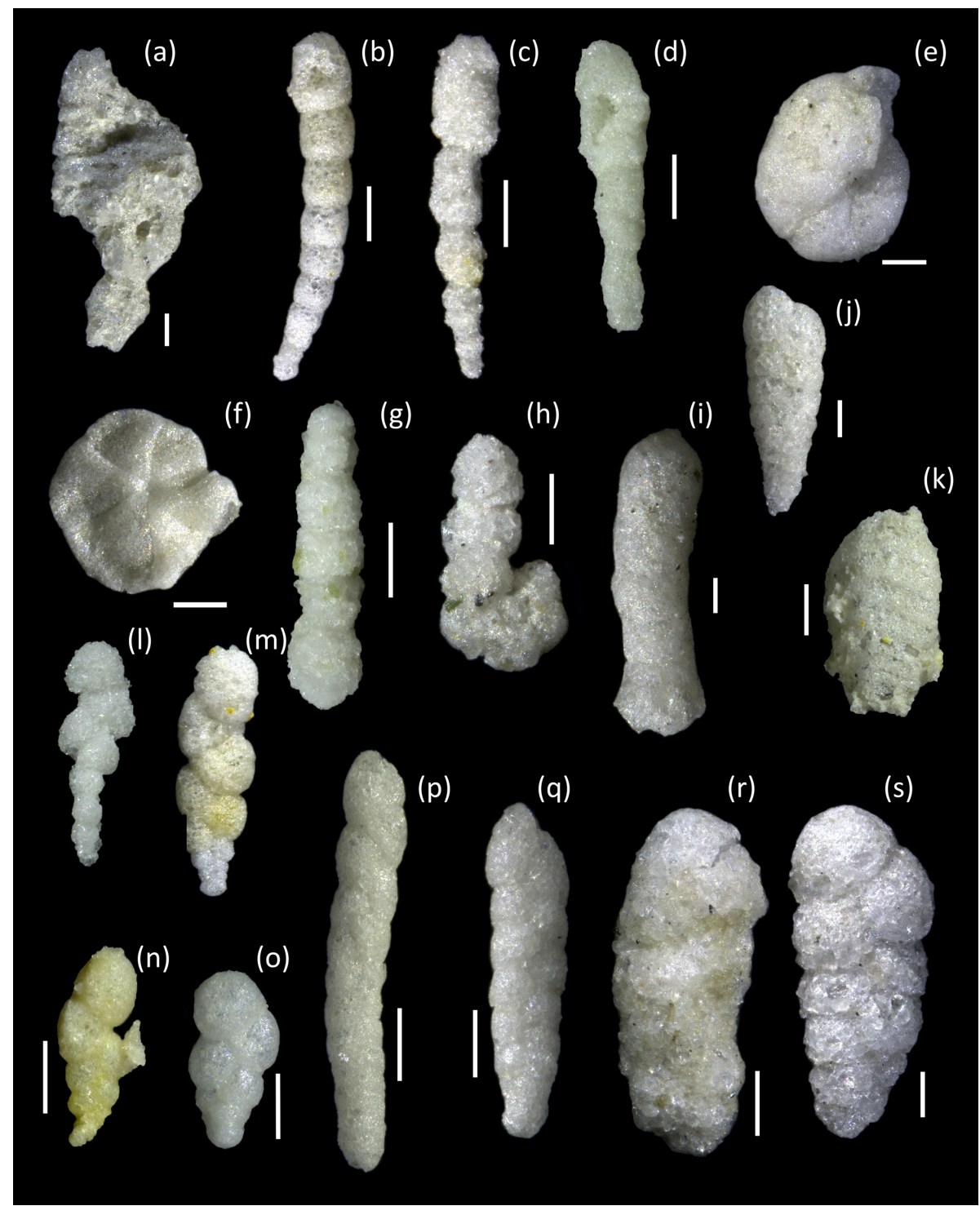

Figure 7. Late Albian to Turonian agglutinated foraminifers from the Lower Saxonian Cretaceous; scale bars are $100 \mu \mathrm{m}$. (a) Reophax subfusiformis, Wunstorf Wu2010/1, 54.00 m. (b) Pseudonodosinella nodulosa, Wunstorf Wu2010/4, 48.20 m. (c) Pseudonodosinella parvula, Wunstorf Wu2010/4, 48.20 m. (d) Pseudonodosinella troyeri, Baddeckenstedt section, 39.00 m. (e) Haplophragmoides suborbicularis, Wunstorf Wu2010/3, 70.50 m. (f) Haplophragmoides walteri, Wunstorf Wu2010/4, 48.95 m. (g) Ammobaculites agglutinans, Söhlde section, 31.00 m. (h) Ammobaculites wenonahae, Wunstorf Wu2010/1, 19.05 m. (i) Bulbobaculites problematicus, Wunstorf Wu2010/1, 24.75 m. (j) Spiroplectammina navarroana, Wunstorf Wu2010/4, 48.20 m. (k) Spiroplectinella cretosa, Baddeckenstedt section, $2.00 \mathrm{~m}$. (l) Bicazammina lagenaria, Söhlde section, 24.00 m. (m) Parvigenerina sp. 3, Wunstorf Wu2010/4, 48.95 m. (n) Eobigenerina kuhnti, Söhlde section, 9.50 m. (o) Eobigenerina variabilis, Söhlde section, 1.50 m. (p) Rectogerochammina eugubina, Wunstorf Wu2010/4, 48.95 m. (q) Gerochammina stanislawi, Wunstorf Wu2010/4, 53.15 m. (r) Plectina cenomana, Wunstorf Wu2010/3, 45.00 m. (s) Plectina mariae, Wunstorf Wu2010/3, $84.00 \mathrm{~m}$.

2008. Haplophragmoides bubiki, Setoyama, Kaminski and Tyska p. 273, pl. 6, figs. 12a-b., pl. 7, figs. 9a-c, 10a-c.

\section{Material}

A total of 20 specimens from the Söhlde section, 17 specimens from the Wunstorf Wu2010/1 core, 5 specimens from the Wunstorf Wu2010/3 core, and 31 specimens from the Wunstorf Wu2010/4 core.

\section{Remarks}

This species was subsequently recorded from the Campanian to Eocene (Setoyama et al., 2011). Our findings extend the known stratigraphic range to early Cenomanian. 


\section{Occurrence}

Lower Cenomanian to middle Turonian of Wunstorf. Uppermost Cenomanian (plenus Bed) to upper Turonian of Söhlde. Very rare.

\section{Haplophragmoides eggeri Cushman 1926}

1926. Haplophragmoides eggeri Cushman p. 583, pl. 15, fig. $1 \mathrm{a}, \mathrm{b}$.

2005. Haplophragmoides eggeri Cushman; Kaminski and Gradstein, p. 342, pl. 75, figs. 1-6.

\section{Material}

A total of 37 specimens from the Baddeckenstedt section, 20 specimens from the Söhlde section, 20 specimens from the Wunstorf Wu2010/1 core, 30 specimens from the Wunstorf Wu2010/3 core, and 19 specimens from the Wunstorf Wu2010/4 core.

\section{Occurrence}

Rare to very rare.

Haplophragmoides pervagatus Krasheninnikov, 1973

1973. Haplophragmoides pervagatus Krasheninnikov, p. 215 , pl. 1 , fig. 7 .

\section{Material}

Two specimens from the Wu2010/1 core and four specimens from the Wunstorf Wu2010/3 core.

\section{Occurrence}

Very rare in the lower Cenomanian at Wunstorf.

Haplophragmoides porrectus Maslakova, 1955

1955. Haplophragmoides porrectus Maslakova, p. 47, pl. 3, figs. 5-6.

1988. Haplophragmoides porrectus Maslakova; Kaminski et al., p. 189 , pl. 5, figs. 7-8.

2005. Haplophragmoides porrectus Maslakova; Kaminski and Gradstein, p. 353, pl. 79, figs. 1a-6.

\section{Material}

Two specimens from the Wunstorf Wu2010/4 core.

\section{Occurrence}

Very rare in the middle Turonian at Wunstorf.

$$
\text { Haplophragmoides stomatus (Grzybowski, 1898) }
$$

1898. Trochammina stomata Grzybowski, p. 290, pl. 11, figs. 26-27.

1993. Haplophragmoides stomatus Grzybowski; Kaminski and Geroch, p. 311, pl. 11, figs. 1a-2b.

2005. Haplophragmoides stomatus Grzybowski; Kaminski and Gradstein, p. 357, pl. 80, figs. 1a-6b.

\section{Material}

Five specimens from the Baddeckenstedt section, four specimens from the Söhlde section, two specimens from the Wunstorf Wu2010/1 core, five specimens from the Wunstorf Wu2010/3 core, and seven specimens from the Wunstorf Wu2010/4 core.

\section{Occurrence}

Very rare.

Haplophragmoides suborbicularis (Grzybowski 1896)

Fig. 6e

1896. Cyclammina suborbicularis Grzybowski p. 63, pl. 9, figs. 5-6.

1988. Haplophragmoides suborbicularis (Grzybowski); Kaminski et al., p. 189, pl. 5, figs. 12-13.

\section{Material}

A total of 22 specimens from the Baddeckenstedt section, 4 specimens from the Söhlde section, 13 specimens from the Wunstorf Wu2010/1 core, 60 specimens from the Wunstorf Wu2010/3 core, and 32 specimens from the Wunstorf Wu2010/4 core.

\section{Occurrence}

Rare.

\section{Haplophragmoides walteri (Grzybowski, 1898)}

Fig. $7 f$

Trochammina walteri Grzybowski, 1898, p. 290, pl. 11, fig. 31 .

1993. Haplophragmoides walteri Grzybowski; Kaminski and Geroch, 1993, p. 263, pl. 10, figs. 3a-7c, p. 309, pl. 10, figs. 3a-c.

2005. Haplophragmoides walteri Grzybowski; Kaminski and Gradstein, 2005, p. 365, pl. 83, figs. 1-6.

\section{Material}

A total of 15 specimens from the Baddeckenstedt section, 17 specimens from the Söhlde section, 46 specimens from 
the Wunstorf Wu2010/1 core, 53 specimens from the Wunstorf Wu2010/3 core, and 27 specimens from the Wunstorf Wu2010/4 core.

\section{Occurrence}

Common to rare in the Cenomanian at Wunstorf, otherwise very rare.

Haplophragmoides spp.

\section{Material}

A total of 2 specimens from the Baddeckenstedt section, 27 specimens from the Söhlde section, 17 specimens from the Wunstorf Wu2010/1 core, 21 specimens from the Wunstorf Wu2010/3 core, and 15 specimens from the Wunstorf Wu2010/4 core.

\section{Occurrence}

Rare to very rare.

Family Lituolidae Blainville 1827

Subfamily Ammomarginulininae Podobina 1978

Genus Ammobaculites Cushman 1910

Ammobaculites agglutinans (d'Orbigny, 1846)

Fig. $7 \mathrm{~g}$

1846. Spirolina agglutinans d'Orbigny, p. 137, pl. 7, figs. 1012.

1952. Ammobaculites agglutinans (d'Orbigny); Bartenstein, p. 318, pl. 1, fig. 1a-c; pl. 2, figs. 10-16.

2005. Ammobaculites agglutinans (d'Orbigny); Kaminski and Gradstein, p. 324, pl. 70, figs. 1-8.

\section{Material}

A total of 45 specimens from the Baddeckenstedt section, 202 specimens from the Söhlde section, 6 specimens from the Wunstorf Wu2010/1 core, 16 specimens from the Wunstorf Wu2010/3 core, and 6 specimens from the Wunstorf Wu2010/4 core.

\section{Occurrence}

Abundant to common in the Turonian of Söhlde, otherwise common to very rare.

Ammobaculites wenonahae Tappan, 1960

Fig. $7 \mathrm{~h}$

1960. Ammobaculites wenonahae Tappan, p. 291, pl. 1, figs. 3-6.

2010. Ammobaculites wenonahae Tappan; Patterson et al., p. 12, figs. 6.18-6.21.

\section{Material}

Four specimens from the Wunstorf Wu2010/1 core, six specimens from the Wunstorf Wu2010/3 core, and three specimens from the Wunstorf Wu2010/4 core.

\section{Occurrence}

Very rare.

Ammobaculites sp.

\section{Material}

A total of 2 specimens from the Söhlde section, 12 specimens from the Wunstorf Wu2010/1 core, 3 specimens from the Wunstorf Wu2010/3 core, and 3 specimens from the Wunstorf Wu2010/4 core.

\section{Remarks}

Mainly fragmented specimens not further determined.

\section{Occurrence}

Very rare.

Family Ammobaculinidae Saidova 1981

Subfamily Ammobaculininae Saidova 1981

Genus Bulbobaculites Maync 1952

Bulbobaculites problematicus (Neagu, 1962)

Fig. 7 i

1962. Ammobaculites agglutinans problematicus Neagu, p. 61 , pl. 2, figs. $22-24$

1970. Ammobaculites problematicus (Neagu); Neagu, p. 39 , pl. 6, figs. 1-5.

1990. Haplophragmium problematicum (Neagu); Kuhnt, p. 312, pl. 4, figs. 3-9.

1990. Bulbobaculites problematicus (Neagu); Kuhnt and Kaminski, p. 465, text fig. 5, 5A

2011. Bulbobaculites problematicus (Neagu); Kaminski et al., p. 92, pl. 5, figs. 5-7.

\section{Material}

A total of 3 specimens from the Baddeckenstedt section, 746 specimens from the Söhlde section, 270 specimens from the Wunstorf Wu2010/1 core, 22 specimens from the Wunstorf Wu2010/3 core, and 969 specimens from the Wunstorf Wu2010/4 core. 


\section{Remarks}

Bulbobaculites problematicus has a wide range of morphological variety (Kuhnt and Kaminski, 1990). It can be used in the Atlantic realm as a post-Cenomanian marker but already appears in the Cenomanian in the Tethys realm of the Carpathians (Neagu, 1962; Huss, 1966; Geroch and Novak, 1984). Tethyan post-Cenomanian assemblages with increased B. problematicus are documented by Bąk (2000). In Wunstorf, this species is noted already in the Albian.

\section{Occurrence}

Very abundant at the Cenomanian-Turonian boundary interval, very abundant to common in the Turonian at Söhlde, common to rare in the Cenomanian at Wunstorf, and very rare at Baddeckenstedt.

Family Placopsilinidae Rhumbler 1913

Subfamily Placopsilininae Rhumbler 1913

Genus Placopsilina d'Orbigny 1850

Placopsilina cenomana d'Orbignyi 1850

1850. Placopsilina cenomana d'Orbignyi, vol. 2, p. 185, n. 758.

1993. Placopsilina cenomana d'Orbignyi; Schmidt and Jäger, p. 153, Fig. 1.

\section{Material}

Two specimens from the Baddeckenstedt section.

\section{Occurrence}

Very rare.

Placopsilina sp.

\section{Material}

One specimen from the Söhlde section.

\section{Occurrence}

Very rare.

Genus Subbdelloidina Frentzen 1944

Subbdelloidina haeusleri Frentzen 1944

1944. Subbdelloidina haeusleri Frentzen, p. 332, pl. 18, figs. 12-22.

1987. Subbdelloidina haeusleri Frentzen; Leary, p. 54, pl. 1, fig. 13.

\section{Material}

A total of 33 specimens from the Baddeckenstedt section.

\section{Occurrence}

Abundant at the sponge beds in the lower Cenomanian at Baddeckenstedt, otherwise rare to very rare at Baddeckenstedt.

Superfamily Recurvoidoidea Alekseychik-Mitskevich 1973

Family Ammosphaeroidinidae Cushman 1927

Subfamily Ammosphaeroidininae Cushman 1927

Genus Ammosphaeroidina Cushman 1910

Ammosphaeroidina pseudopauciloculata (Mjatliuk, 1966)

1966. Cystamminella pseudopauciloculata Mjatliuk, p. 264, pl. 1, figs. 5-8; pl. 2, fig. 6; pl. 3, fig. 3.

1988. Ammosphaeroidina pseudopauciloculata (Mjatliuk); Kaminski et al., p. 193, pl. 8, figs. 3a-5.

2011. Ammosphaeroidina pseudopauciloculata (Mjatliuk); Kaminski et al., p. 91, pl. 4, fig. 16.

\section{Material}

A total of 38 specimens from the Söhlde section.

\section{Occurrence}

Common to very rare in the middle and upper Turonian at Söhlde.

Genus Praecystammina Krasheninnikov 1973

Praecystammina sp.

\section{Material}

Two specimens from the Söhlde section.

\section{Occurrence}

Very rare in the middle Turonian of Söhlde. Subfamily Recurvoidinae Alekseychik-Mitskevich
1973

Genus Recurvoides Earland 1934

Recurvoides sp.

\section{Material}

A total of 10 specimens from the Baddeckenstedt section and five specimens from the Söhlde section. 


\section{Occurrence}

Very rare.

Suborder Spiroplectamminina Mikhalevich 1992

Superfamily Spiroplectamminoidea Cushman 1927

Family Spiroplectamminidae Cushman 1927

Subfamily Spiroplectammininae Cushman 1927

Genus Spiroplectammina Cushman 1927

Spiroplectammina navarroana Cushman, 1932

Fig. $7 j$

1932. Spiroplectammina navarroana Cushman, p. 96, pl. 11, fig. 14.

1989. Spiroplectammina navarroana Cushman; Gradstein and Kaminski, p. 83, pl. 9, figs. 1a-12.

2005. Spiroplectammina navarroana Cushman; Kaminski and Gradstein, p. 426, pl. 103, figs. 1a-12.

2017. Spiroplectammina navarroana Cushman; Setoyama et al., p. 196, pl. 2, fig. 12.

\section{Material}

A total of 70 specimens from the Baddeckenstedt section, 338 specimens from the Söhlde section, 8 specimens from the Wunstorf Wu2010/3 core, and 285 specimens from the Wunstorf Wu2010/4 core.

\section{Occurrence}

First occurrence in the lower Cenomanian above The Rib. Very abundant in the Cenomanian-Turonian boundary interval at Wunstorf and in the upper Turonian at Söhlde, abundant to common in the upper Cenomanian to Turonian, and very rare in the lower to middle Cenomanian.

\section{Spiroplectammina sp.}

\section{Material}

In total eight specimens from the Söhlde section.

\section{Occurrence}

Very rare.

Genus Spiroplectinella Kisel'man 1972

Spiroplectinella cretosa (Cushman, 1932)

Fig. 7k

1932. Spiroplectammina laevis (Roemer) var. cretosa Cushman, pl. 11, fig. 3 .
1972. Spiroplectammina cretosa Cushman; Hanzlíková, pl. 10. Fig. 9.

1997. Spiroplectinella cretosa (Cushman); Holbourn and Kaminski, p. 136, pl. 2, figs. 4-7.

\section{Material}

A total of 29 specimens from the Baddeckenstedt section, 4 specimens from the Wunstorf Wu2010/1 core, and 2 specimens from the Wunstorf Wu2010/3 core.

\section{Occurrence}

Rare to very rare in the lower and middle Cenomanian of Lower Saxony.

Family Textulariopsidae Loeblich and Tappan 1982

Genus Bicazammina Neagu and Neagu 1995

Bicazammina lagenaria (Krasheninnikov, 1974)

Fig. 71

1974. Pseudobolivina lagenaria Krasheninnikov, p. 639, pl. 5, figs. 1a-b, 2c.

1990. Pseudobolivina lagenaria Krasheninnikov; Kuhnt, p. 322, pl. 6, figs. 3-6.

2008. Bicazammina lagenaria (Krasheninnikov); Cetean et al., p. 24, tab. 1, pl. 1, fig. 17.

2011. Bicazammina lagenaria (Krasheninnikov); Kaminski et al., p. 92, pl. 5, figs. 10-11.

\section{Material}

A total of 4 specimens from the Baddeckenstedt section, 29 specimens from the Söhlde section, 2 specimens from the Wunstorf Wu2010/3 core, and 40 specimens from the Wunstorf Wu2010/4 core.

\section{Occurrence}

Rare to very rare.

Genus Rashnovammina Neagu and Neagu 1995

Rashnovammina munda (Krasheninnikov, 1974)

1974. Pseudobolivina munda Krasheninnikov, p. 210, pl. 2, figs. 10, 11.

1990. Pseudobolivina sp. cf. munda (Krasheninnikov); Kuhnt, p. 324, pl. 6, figs. 1, 2 .

2008. Rashnovammina munda (Krasheninnikov); Cetean et al., p. 138, pl. 1, fig. 14.

2011. Rashnovammina munda (Krasheninnikov); Kaminski et al., p. 93, pl. 5, fig. 16. 


\section{Material}

One specimen from the Wunstorf Wu2010/3 core and one specimen from the Wunstorf Wu2010/4 core.

\section{Occurrence}

Very rare.

Genus Textulariopsis Banner and Pereira 1981

Textulariopsis rioensis (Carsey, 1926)

1926. Textularia rioensis Carsey, p. 24, pl. 7, fig. 2.

1982. Textulariopsis rioensis (Carsey), Loeblich and Tappan, p. 67 , pl. 2, figs. $26-28$.

\section{Material}

One specimen from the Baddeckenstedt and three specimens from the Wunstorf Wu2010/1 core.

\section{Occurrence}

Very rare.

Textulariopsis $\mathrm{sp}$.

\section{Material}

One specimen from the Söhlde section.

\section{Occurrence}

Very rare.

Family Pseudobolivinidae Wiesner 1931

Genus Parvigenerina Vella 1957

Parvigenerina sp. 3 (Kuhnt 1990)

Fig. $7 \mathrm{~m}$

1990. Pseudobolivina sp. 3 Kuhnt, p. 324, pl. 6, fig. 5.

2008. Parvigenerina sp. 3 (Kuhnt); Cetean et al., p. 23, pl. 1, figs. 20, 21.

2011. Parvigenerina sp. 3 (Kuhnt); Kaminski et al., p. 93, pl. 5, figs. 13-14.

\section{Material}

A total of 2 specimens from the Baddeckenstedt section, 93 specimens from the Söhlde section, 7 specimens from the Wunstorf Wu2010/3 core, and 95 specimens from the Wunstorf Wu2010/4 core.

\section{Occurrence}

Common to rare in the middle Turonian, otherwise rare to very rare.

Suborder Trochamminina Saidova 1981

Superfamily Trochamminoidea Schwager 1877

Family Trochamminidae Schwager 1877

Subfamily Trochammininae Schwager 1877

Genus Trochammina Parker and Jones 1859

Trochammina spp.

\section{Material}

A total of 39 specimens from the Baddeckenstedt section, 124 specimens from the Söhlde section, 20 specimens from the Wunstorf Wu2010/1 core, 42 specimens from the Wunstorf Wu2010/3 core, and 35 specimens from the Wunstorf Wu2010/4 core.

\section{Occurrence}

Common to very rare.

Suborder Verneuilinina Mikhalevich and Kaminski 2004

Superfamily Verneuilinoidea Cushman 1911

Family Prolixoplectidae Loeblich and Tappan 1985

Genus Eobigenerina Cetean, Setoyama, Kaminski, Neagu, Bubík, Filipescu and Tyszka 2008

Eobigenerina kuhnti Cetean, Setoyama, Kaminski, Neagu, Bubík, Filipescu and Tyszka 2008

Fig. 7n

2008. Eobigenerina kuhnti Cetean, Setoyama, Kaminski, Neagu, Bubík, Filipescu and Tyszka, p. 22, pl. 1, figs. 1316.

\section{Material}

A total of specimen from the Baddeckenstedt section, 17 specimens from the Söhlde section, 2 specimens from the Wunstorf Wu2010/3 core, and 5 specimens from the Wunstorf Wu2010/4 core. 


\section{Occurrence}

Very rare.

\section{Eobigenerina variabilis (Vašíček, 1947)}

Fig. 70

1947. Bigenerina variabilis Vašíček, p. 246, pl. 1, figs. 1012.

1970. Pseudobolivina variabilis (Vašíček); Neagu, p. 41, pl. 5, figs. 13-16.

2008. Eobigenerina variabilis (Vašíček); Cetean et al., p. 67.

2011. Eobigenerina variabilis (Vašíček); Kaminski et al., p. 92 , pl. 5 , figs. $12 \mathrm{a}-\mathrm{b}$.

\section{Material}

A total of 11 specimens from the Baddeckenstedt section, 101 specimens from the Söhlde section, 5 specimens from the Wunstorf Wu2010/1 core, 6 specimens from the Wunstorf Wu2010/3 core, and 278 specimens from the Wunstorf Wu2010/4 core.

\section{Occurrence}

Very abundant in the Cenomanian-Turonian boundary interval, abundant to rare in the Turonian, and very rare in the Cenomanian.

Genus Rectogerochammina Kaminski, Cetean and Neagu 2010

Rectogerochammina eugubina Kaminski, Cetean and Neagu 2010

Fig. $7 p$

2010. Rectogerochammina eugubina Kaminski, Cetean and Neagu, p. 122, text-figs. 1-2.

2011. Rectogerochammina eugubina Kaminski, Cetean and Neagu; Kaminski et al., p. 94, pl. 5, figs. 17a-b.

\section{Material}

A total of 55 specimens from the Söhlde section, 1 specimen from the Wunstorf Wu2010/1 core, 1 specimen from the Wunstorf Wu2010/3 core, and 80 specimens from the Wunstorf Wu2010/4 core.

\section{Occurrence}

Common to rare in the Turonian, very rare in the Cenomanian, and absent in Baddeckenstedt.

Genus Gerochammina Neagu 1990
Gerochammina stanislawi Neagu, 1990

Fig. 7q

1990. Gerochammina stanislawi Neagu, p. 253, pl. 1, figs 126.

\section{Material}

A total of 56 specimens from the Baddeckenstedt section, 168 specimens from the Söhlde section, 8 specimens from the Wunstorf Wu2010/1 core, 10 specimens from the Wunstorf Wu2010/3 core, and 194 specimens from the Wunstorf Wu2010/4 core.

\section{Occurrence}

Common to very rare in the Cenomanian up to lower Turonian and abundant to rare in the middle and upper Turonian.

Genus Kadriayina Al-Najdi 1975

Kadriayina gradata (Berthelin, 1880)

Fig. $7 \mathrm{t}$

1880. Gaudryina gradata Berthelin, p. 24, pl. 1, figs. 6a-c. 1972. Dorothia gradata (Berthelin); Gawor-Biedowa, p. 29, pl. 2, figs. 7a-b.

1997. Kadriayina gradata (Berthelin); Holbourn and Kaminski, p. 51.

\section{Material}

A total 86 specimens from the Baddeckenstedt section, 4 specimens from the Söhlde section, 168 specimens from the Wunstorf Wu2010/1 core, 149 specimens from the Wunstorf Wu2010/3 core, and 12 specimens from the Wunstorf Wu2010/4 core.

\section{Occurrence}

Uppermost Albian and Cenomanian, abundant to common in the Cenomanian at Wunstorf, and common to rare at Baddeckenstedt.

Genus Plectina Marsson 1878

Plectina cenomana Carter and Hart, 1977

Fig. 7r

1977. Plectina cenomana Carter and Hart, p. 12, pl. 2, fig. 9 1980. Plectina cenomana Carter and Hart; Frieg, p. 235, textfig. 2.4. 


\section{Material}

A total 345 specimens from the Baddeckenstedt section, 15 specimens from the Söhlde section, 15 specimens from the Wunstorf Wu2010/1 core, 127 specimens from the Wunstorf Wu2010/3 core, and 17 specimens from the Wunstorf $\mathrm{Wu} 2010 / 4$ core.

\section{Occurrence}

Abundant to common in the lower Cenomanian from the crippsi Event onwards to the upper Cenomanian below OAE2.

\section{Plectina mariae (Franke, 1928)}

Fig. 7s

1928. Gaudryina ruthenica Reuss f. mariae Franke, p. 146, pl. 13, figs. $15 \mathrm{a}, \mathrm{b}$.

1937. Plectina ruthenica Reuss var. mariae (Franke); Cushman, p. 106, pl. 11, fig. 15.

1977. Plectina mariae (Franke); Carter and Hart, p. 13, pl. 2, fig. 8 .

1980. Plectina mariae (Franke); Frieg, text-figs. 2.5-6.

\section{Material}

A total of 102 specimens from the Baddeckenstedt section, 2 specimens from the Söhlde section, 1 specimen from the Wunstorf Wu2010/1 core, 15 specimens from the Wunstorf Wu2010/3 core, and 8 specimens from the Wunstorf $\mathrm{Wu} 2010 / 4$ core.

\section{Occurrence}

Common to very rare in the lower Cenomanian from the crippsi Event onwards to the upper Cenomanian below OAE2.

Family Tritaxiidae Plotnikova 1979

Genus Tritaxia Reuss 1860

Tritaxia gaultina (Morozowa, 1948)

Fig. 8a

1948. Clavulina gaultina Morozowa, p. 36, pl. 1, fig. 4. 1970. Tritaxia gaultina (Morozowa); Neagu.

\section{Material}

A total of 123 specimens from the Wunstorf Wu2010/1 core and 1 specimen from the Wunstorf Wu2010/4 core.

\section{Occurrence}

Abundant to common in the lower Cenomanian at Wunstorf between the crippsi Event and The Rib, otherwise very rare.

Tritaxia macfadyeni Cushman, 1936

Fig. $8 b$

1936. Tritaxia macfadyeni Cushman, p. 3, pl. 1m figs. 6a, b.

\section{Material}

A total of 39 specimens from the Wunstorf Wu2010/1 core and three specimens from the Wunstorf Wu2010/4 core.

\section{Remarks}

Always smaller than $T$. tricarinata and with a much more rounded and smooth cross section.

\section{Occurrence}

Mass occurrence (abundant) in the lower Cenomanian of Wunstorf around the crippsi Event, otherwise very rare.

Tritaxia tricarinata (Reuss 1845)

Fig. 8c

1845. Textularia tricarinata Reuss, p. 39, pl. 8, fig. 60.

1863. Dentalinopsis tricarinatum (Reuss); Reuss, p. 119, pl. 18, fig. 13.

1892. Tritaxia tricarinata (Reuss); Chapman, p. 34-35, pl. 11 , fig. 1 .

1972. Tritaxia tricarinata (Reuss); Hanzlíková, p. 54, pl. 11, fig. 11.

1980. Tritaxia tricarinata (Reuss); Frieg, p. 234.

\section{Material}

A total of 722 specimens from the Baddeckenstedt section, 14 specimens from the Söhlde section, 387 specimens from the Wunstorf Wu2010/1 core, 371 specimens from the Wunstorf Wu2010/3 core, and 86 specimens from the Wunstorf Wu2010/4 core.

\section{Remarks}

Frieg (1980) showed a clear transition of the suture angles between Tritaxia tricarinata and $T$. pyramidata (Reuss). $T$. pyramidata must be seen as a junior synonym.

\section{Occurrence}

Very abundant to common in the Cenomanian, abundant to very rare in the Turonian at Wunstorf, and rare to very rare at Söhlde. 


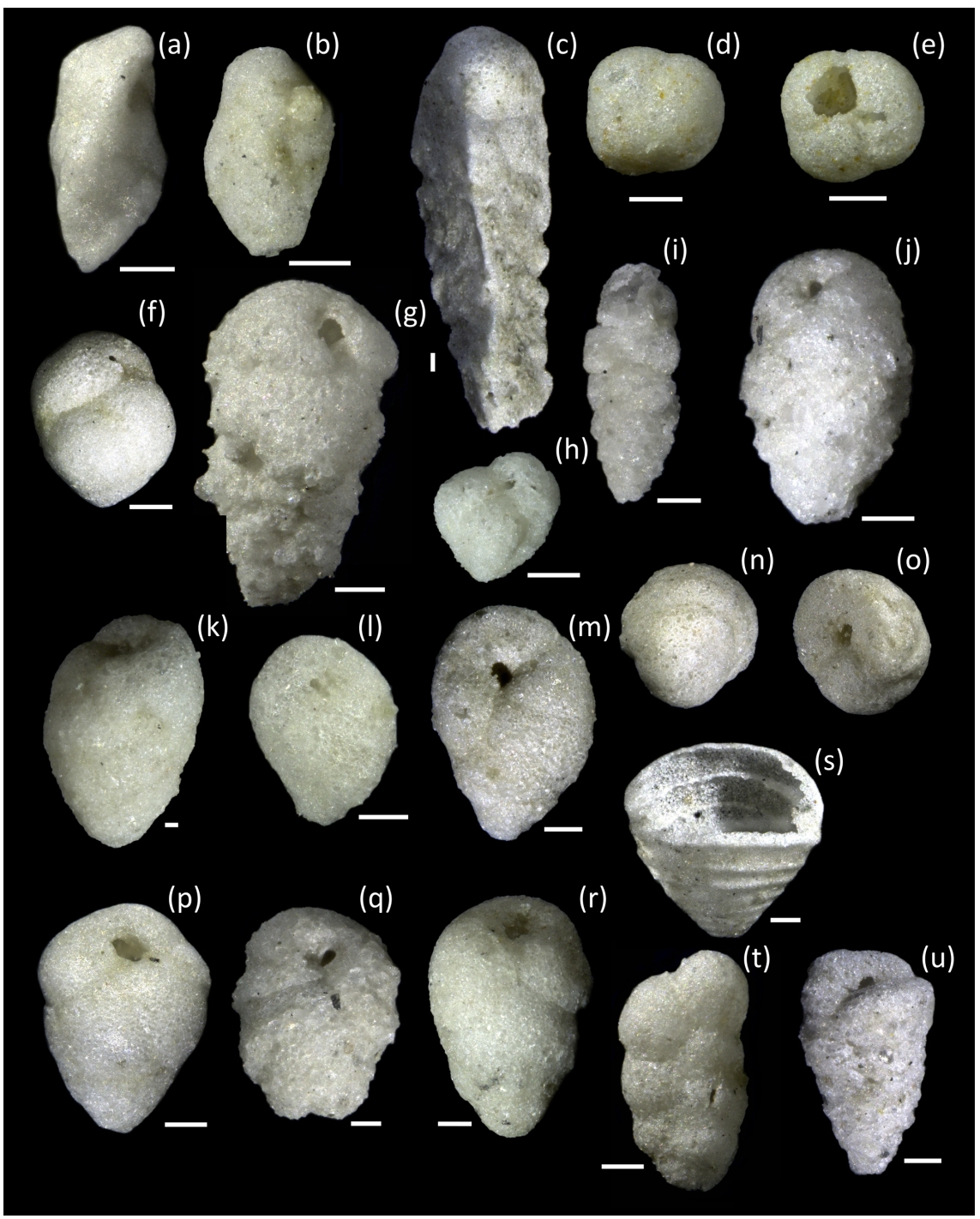

Figure 8. Late Albian to Turonian agglutinated foraminifers from the Lower Saxonian Cretaceous; scale bars are $100 \mu \mathrm{m}$. (a) Tritaxia gaultina, Wunstorf Wu2010/1, 19.05 m. (b) Tritaxia tricarinata, Wunstorf Wu2010/1, 19.05 m. (c) Tritaxia macfadyeni, Wunstorf Wu2010/1, 34.10 m. (d-e) Eggerellina brevis, Baddeckenstedt section, 19.30 m. (f) Eggerellina mariae, Wunstorf Wu2010/3, 30.15 m. (g) Flourensina intermedia, Wunstorf Wu2010/1, 54.80 m. (h) Gaudryina sp. 1, Baddeckenstedt section, $39.00 \mathrm{~m}$. (i) Verneuilinoides sp., Wunstorf Wu2010/4, 48.95 m. (j) Vialovella frankei, Wunstorf Wu2010/1, 15.20 m. (k) Arenobulimina bochumensis, Baddeckenstedt section, 9.00 m. (l) Arenobulimina preslii, Wunstorf Wu2010/4, 43.30 m. (m) Arenobulimina truncata, Wunstorf Wu2010/4, 43.30 m. (n-o) Ataxophragmium depressum, Wunstorf Wu2010/4, 58.60 m. (p) Hagenowella elevata, Wunstorf Wu2010/4, 58.60 m. (q) Voloshinoides advenus, Wunstorf Wu2010/1, 29.25 m. (r) Voloshinoides anglicus, Baddeckenstedt section, 7.00 m. (s) Pseudotextulariella cretosa, Wunstorf Wu2010/1, 19.05 m. (t) Kadriayina gradata, Wunstorf Wu2010/3, 66.05 m. (u) Marssonella ozawai, Wunstorf Wu2010/1, 15.20 m.

Family Verneuilinidae Cushman 1911

Subfamily Verneuilinoidinae Suleymanov 1973

Genus Eggerellina Marie 1941

Eggerellina brevis (d'Orbignyi, 1840)

Fig. 8d-e

1840. Bulimina brevis d'Orbignyi, p. 41, pl. 4, figs. 13-14.
1972. Eggerellina brevis (d'Orbignyi); Voloshina, p. 92, pl. 9, figs. 2-3; pl. 21, fig. 2.

\section{Material}

A total of 275 specimens from the Baddeckenstedt section, 92 specimens from the Söhlde section, 59 specimens from the Wunstorf Wu2010/1 core, 62 specimens from the Wunstorf Wu2010/3 core, and 46 specimens from the Wunstorf Wu2010/4 core. 


\section{Occurrence}

Common to very rare at Wunstorf, abundant to common at Baddeckenstedt, and common to very rare at Söhlde.

Eggerellina mariae Ten Dam, 1950

Fig. $8 f$

1950. Eggerellina mariae Ten Dam, p. 15, pl. 1, figs. 17a-e. 1975. Eggerellina mariae Ten Dam; Magniez-Jannin, p. 94, pl. 6, figs. 12-21.

\section{Material}

A total of 282 specimens from the Baddeckenstedt section, 51 specimens from the Söhlde section, 121 specimens from the Wunstorf Wu2010/1 core, 75 specimens from the Wunstorf Wu2010/3 core, and 14 specimens from the Wunstorf Wu2010/4 core.

\section{Occurrence}

Abundant to common in the Cenomanian and rare to very rare in the Turonian.

Genus Flourensina Marie 1938

Flourensina intermedia Ten Dam, 1950

Fig. 8g

1950. Flourensina intermedia Ten Dam, p. 15, pl. 1, fig. 16.

\section{Material}

A total of 35 specimens from the Baddeckenstedt section, 253 specimens from the Wunstorf Wu2010/1 core, 213 specimens from the Wunstorf Wu2010/3 core, and 1 specimen from the Wunstorf Wu2010/4 core.

\section{Remarks}

The systematic position, occurrence, and paleogeographical distribution of Flourensina intermedia is intensively discussed in Frieg and Kemper (1989). Like observed in the Konrad 101 core, and outcrops in the Münsterland Basin, Flourensina intermedia occurs frequently over the whole Cenomanian in Baddeckenstedt.

\section{Occurrence}

Abundant to common in the uppermost Albian up to the upper Cenomanian until below the Facies Change at Wunstorf and common to very rare in the Cenomanian at Baddeckenstedt.

Genus Gaudryinopsis Podobina 1975
Gaudryinopsis filiformis (Berthelin, 1880)

1880. Gaudryina filiformis Berthelin, p. 25, pl. 1, fig. 8a-d. 1937. Dorothia filiformis (Berthelin); Cushman, p. 73, pl. 8, figs. 1-2.

1993. Gaudryinopsis filiformis (Berthelin); Haig and Lynch, p. 346.

\section{Material}

A total of 34 specimens from the Baddeckenstedt section, 13 specimens from the Söhlde section, 25 specimens from the Wunstorf Wu2010/1 core, and 7 specimens from the Wunstorf $\mathrm{Wu} 2010 / 3$ core.

\section{Occurrence}

Rare to very rare in the uppermost Albian to upper Cenomanian.

Genus Verneuilinoides Loeblich and Tappan 1949

Verneuilinoides spp.

Fig. 8i

\section{Material}

A total of 35 specimens from the Baddeckenstedt section, 92 specimens from the Söhlde section, 3 specimens from the Wunstorf Wu2010/3 core, and 48 specimens from the Wunstorf Wu2010/4 core.

\section{Occurrence}

Common to very rare.

Genus Vialovella Voloshina 1972

Vialovella frankei (Cushman, 1936)

Fig. 8j

1936. Arenobulimina frankei Cushman, p. 27, pl. 4, figs. 5ab.

1969. Arenobulimina frankei Cushman; Gawor-Biedowa, p. 84, pl. 5, figs. 4, 5, pl. 7, figs. 6-8.

1972. Vialovella frankei (Cushman); Voloshina, p. 87, pl. 8, fig. 8 .

1977. Arenobulimina frankei Cushman; Carter and Hart, p. 15 , pl. 1, fig. 1, pl. 2, fig. 5 .

1982. Vialovella praefrankei (Cushman); Frieg and Price, p. 47, pl. 2.1., figs. a-c.

1989. Vialovella frankei (Cushman); Frieg and Kemper, p. 104, pl. 15, figs. 12-20. 


\section{Material}

A total of 443 specimens from the Baddeckenstedt section, 38 specimens from the Söhlde section, 297 specimens from the Wunstorf Wu2010/1 core, 269 specimens from the Wunstorf Wu2010/3 core, and 19 specimens from the Wunstorf Wu2010/4 core.

\section{Remarks}

Initially described as Arenobulimina frankei by Cushman (1936), Frieg and Price (1982), and Frieg and Kemper (1989) described the clearly triserial chamber arrangement of this species. Therefore, we follow their classification as Vialovella frankei.

\section{Occurrence}

Very abundant to common in the uppermost Albian up to the upper Cenomanian. Last occurrence below the Facies Change at Söhlde and Baddeckenstedt and in the plenus Bed at Wunstorf.

Family Reophacellidae Mikhalevich and Kaminski 2004

Genus Gaudryina d'Orbignyi 1839

Gaudryina sp.1

Fig. $8 \mathrm{~h}$

\section{Material}

A total of 108 specimens from the Baddeckenstedt section, 7 specimens from the Söhlde section, 24 specimens from the Wunstorf Wu2010/1 core, 66 specimens from the Wunstorf Wu2010/3 core, and 5 specimens from the Wunstorf Wu2010/4 core.

\section{Remarks}

Test free, elongate, triserial and triangular in section, biserial part reduced, finely to medium-grained agglutinated, chambers are inflated, and sutures commonly distinct.

\section{Occurrence}

Common to rare in the Cenomanian until below the Facies Change.

\section{Genus Uvigerinammina Majzon 1943}

Uvigerinammina jankoi Majzon, 1943

1943. Uvigerinammina jankoi Majzon, p. 158, pl. 2, fig. 15a, b.

1995. Uvigerinammina jankoi Majzon; Bubík, p. 89, pl. 13, fig. 13 .
2011. Uvigerinammina jankoi Majzon; Kaminski et al., p. 94 , pl. 5 , fig. 19.

2017. Uvigerinammina jankoi Majzon; Setoyama et al., p. 197 , pl. 4, figs. $8-9$.

\section{Material}

A total of 17 specimens from the Söhlde section.

\section{Occurrence}

Rare to very rare in the middle and upper Turonian of Söhlde.

Subfamily Spiroplectinatinae Cushman 1928

Genus Spiroplectinata Cushman 1927

Spiroplectinata bettenstaedti Grabert, 1959

1959. Spiroplectinata bettenstaedti Grabert, p. 15, pl. 1, figs. 14-15; pl. 2, figs. 42-45; pl. 3, figs. 89-90.

\section{Material}

One specimen from the Wunstorf Wu2010/3 core.

\section{Occurrence}

Very rare in the lower Cenomanian.

Subfamily Verneuilininae Cushman 1911

Genus Gaudryinella Plummer 1931

Gaudryinella irregularis Tappan, 1943

1943. Gaudryinella irregularis Tappan, p. 493, pl. 78, figs. 22-24.

1990. Gaudryinella irregularis Tappan; Weidich, p. 104, pl. 9, figs. 10-11; pl. 35, fig. 7.

\section{Material}

A total of 39 specimens from the Söhlde section.

\section{Occurrence}

Rare to very rare in the middle and upper Turonian of Söhlde.

Order Loftusiida Kaminski and Mikhalevich 2004

Suborder Ataxophragmiina Fursenko 1958

Superfamily Ataxophragmioidea Schwager 1877

Family Ataxophragmiidae Schwager 1877

Subfamily Ataxophragmiinae Schwager 1877

Genus Arenobulimina Cushman 1927 
Arenobulimina barnardi Frieg and Price, 1982

1982. Arenobulimina barnardi Frieg and Price, p. 58, pl. 2.2, fig. f.

1989. Arenobulimina (Pasternakia) barnardi (Frieg and Price); Frieg and Kemper, p. 90, pl. 2, figs. 1-5.

\section{Material}

A total of 81 specimens from the Baddeckenstedt section, 15 specimens from the Söhlde section, 121 specimens from the Wunstorf Wu2010/1 core, 75 specimens from the Wunstorf Wu2010/3 core, and 9 specimens from the Wunstorf $\mathrm{Wu} 2010 / 4$ core.

\section{Occurrence}

Common in the uppermost Albian and lower Cenomanian of Wunstorf, otherwise rare to very rare.

\section{Arenobulimina bochumensis Frieg, 1980}

Fig. 8k

1980. Arenobulimina bochumensis Frieg, p. 235, pl. 2, figs. 1-3.

1989. A. (Pasternakia) bochumensis Frieg; Frieg and Kemper, p. 90, pl. 3, figs. 1-29.

\section{Material}

A total of 16 specimens from the Baddeckenstedt section, 75 specimens from the Söhlde section, 16 specimens from the Wunstorf Wu2010/1 core, 25 specimens from the Wunstorf Wu2010/3 core, and 162 specimens from the Wunstorf Wu2010/4 core.

\section{Occurrence}

Common to rare in the Turonian and very rare in the Cenomanian.

Arenobulimina improcera Voloshina, 1972

1972. Arenobulimina improcera Voloshina, p.71, pl. 4, fig. 2. 1982. Arenobulimina (Harena) improcera Voloshina; Frieg and Price, p. 57, pl. 2.1, fig. j.

\section{Material}

A total of 18 specimens from the Wunstorf Wu2010/3 core.

\section{Occurrence}

Very rare in the lower Cenomanian of Wunstorf above The Rib.

Arenobulimina preslii (Reuss, 1845)
Fig. 81

1845. Bulimina preslii Reuss, p. 38, pl. 13, fig. 72.

1972. Arenobulimina preslii (Reuss); Voloshina, p. 59, pl. 1, figs. 2-3.

1982. A. (Arenobulimina) preslii (Reuss); Frieg and Price, p. 52, pl. 2.1., figs. d-h

1989. A. (Arenobulimina) preslii (Reuss); Frieg and Kemper, p. 89 , pl. 1, figs. 1-22.

\section{Material}

A total of 135 specimens from the Baddeckenstedt section, 75 specimens from the Söhlde section, 79 specimens from the Wunstorf Wu2010/1 core, 75 specimens from the Wunstorf Wu2010/3 core, and 345 specimens from the Wunstorf Wu2010/4 core.

\section{Occurrence}

Very abundant to common in the Turonian at Wunstorf, otherwise common to very rare. First occurrence between $u l$ timus/Aucellina and crippsi events.

\section{Arenobulimina truncata (Reuss, 1844)}

Fig. $8 \mathrm{~m}$

1844. Bulimina truncata Reuss, p. 215, pl. 8, fig. 73.

1937. Arenobulimina truncata (Reuss); Cushman, p. 40, pl. 4, figs. 15, 16 .

\section{Material}

A total of 217 specimens from the Baddeckenstedt section, 132 specimens from the Söhlde section, 314 specimens from the Wunstorf Wu2010/1 core, 162 specimens from the Wunstorf Wu2010/3 core, and 227 specimens from the Wunstorf Wu2010/4 core.

\section{Occurrence}

Abundant to common and absent at the CenomanianTuronian boundary interval.

Arenobulimina spp.

\section{Material}

A total of 113 specimens from the Baddeckenstedt section, 29 specimens from the Söhlde section, 332 specimens from the Wunstorf Wu2010/1 core, 306 specimens from the Wunstorf Wu2010/3 core, and 131 specimens from the Wunstorf Wu2010/4 core.

\section{Remarks}

Broken, indeterminable specimens. 


\section{Occurrence}

Common to very rare.

Genus Ataxophragmium Reuss 1860

Ataxophragmium compactum Brotzen, 1936

1936. Ataxophragmium compactum, Brotzen, p. 42, pl. 2, figs. 3, 10 .

\section{Material}

Two specimens from the Baddeckenstedt section and two specimens from the Wunstorf Wu2010/4 core.

\section{Occurrence}

Very rare.

Ataxophragmium depressum (Perner, 1892)

Fig. $8 \mathrm{n}-\mathrm{O}$

1882. Bulimina depressa, Perner, p. 55, pl. 3, fig. 3.

1937. Pernerina depressa (Perner); Cushman, p. 195, pl. 21, figs. 5-9.

1972. Ataxophragmium aff. depressum (Perner); Voloshina, p. 104, pl. 11, fig. 6 .

1980. Ataxophragmium depressum (Perner); Frieg, p. 237, text-figs. 2. 9-10.

\section{Material}

A total of 51 specimens from the Baddeckenstedt section, 4 specimens from the Söhlde section, and 13 specimens from the Wunstorf Wu2010/4 core.

\section{Occurrence}

Common to very rare.

Ataxophragmium sp.

\section{Material}

Three specimens from the Söhlde section.

\section{Remarks}

Broken, indeterminable specimens.

\section{Occurrence}

Very rare.

Genus Hagenowella Cushman 1933

Hagenowella elevata (d'Orbignyi, 1840)
Fig. $8 p$

1840. Globigerina elevata d'Orbignyi, p. 34, pl. 3, figs. 1516.

1972. Arenobulimina (Novatrix) elevata (d'Orbignyi); Voloshina, p. 78, pl. 15, fig. 3, pl. 6, fig. 1, pl. 21, fig. 1.

1982. Arenobulimina (Hagenowella) elevata (d'Orbignyi); Frieg and Price, p. 55, pl. 2.1., fig. 1; pl. 2.2., figs. a-b. 1989. Hagenowella elevata (d'Orbignyi); Frieg and Kemper, p. 98, pl. 2, figs. 6-9.

\section{Material}

A total of 187 specimens from the Baddeckenstedt section, 88 specimens from the Söhlde section, 33 specimens from the Wunstorf Wu2010/1 core, 61 specimens from the Wunstorf Wu2010/3 core, and 169 specimens from the Wunstorf Wu2010/4 core.

\section{Occurrence}

Abundant to common in the Cenomanian of Baddeckenstedt and in the Turonian of Wunstorf, otherwise rare to very rare.

Hagenowella obesa (Reuss, 1851)

1851. Bulimina obesa Reuss, p. 40, pl. 4, fig. 12; pl. 5, fig. 1. 1937. Arenobulimina obesa (Reuss); Cushman, p. 43, pl. 4, figs. 26, 27.

1982. Arenobulimina (Hagenowella) obesa (Reuss); Frieg and Price, p. 56, pl. 2.2., figs. c-d; pl. 2.3., fig. i.

\section{Material}

A total of 90 specimens from the Baddeckenstedt section, 16 specimens from the Söhlde section, 18 specimens from the Wunstorf Wu2010/1 core, 52 specimens from the Wunstorf Wu2010/3 core, and 31 specimens from the Wunstorf Wu2010/4 core.

\section{Occurrence}

Common to very rare in the Cenomanian to the upper Turonian.

Subfamily Pernerininae Loeblich and Tappan 1984

Genus Voloshinoides Barnard and Banner 1980

Voloshinoides advenus (Cushman, 1936)

Fig. $8 \mathrm{q}$

1936. Hagenowella advena Cushman, p. 43, pl. 6, fig. 21. 1969. Arenobulimina advena (Cushman); Gawor-Biedowa, p. 86 , pl. 8 , figs. $1-4$. 
1977. Arenobulimina advena (Cushman); Carter and Hart, p. 14 , pl. 2, fig. 4 .

1982. Hagenowina advena (Cushman); Frieg and Price, p. 68, pl. 2.3, figs. g, h.

1989. Voloshinoides advena (Cushman); Frieg and Kemper, p. 94, pl. 5, figs. 5-8, 21-27; pl. 7, fig. 3; pl. 10, figs. 8-15; pl. 11, figs. 10-11.

\section{Material}

A total of 216 specimens from the Baddeckenstedt section, 199 specimens from the Wunstorf Wu2010/1 core, and 184 specimens from the Wunstorf Wu2010/3 core.

\section{Remarks}

This study follows the intensively discussed generic affiliation of this species by Frieg and Kemper (1989).

\section{Occurrence}

Abundant to common in the uppermost Albian to middle Cenomanian and rare to very rare in the upper Cenomanian below the Facies Change.

Voloshinoides anglicus (Cushman, 1936)

Fig. 8r

1936. Arenobulimina anglica Cushman, p. 27, pl. 4, fig. 8. 1982. Hagenowina anglica (Cushman); Frieg and Price, p. 68, pl. 2.3, figs. i-m.

1989. Voloshinoides anglicus (Cushman); Frieg and Kemper, p. 95, pl. 5, figs. 1-4; pl. 6, figs. 1-6; pl. 7, fig. 8; pl. 8, figs. 2$3,5-8,11-12$; pl. 9 , figs. $1-4$; pl. 10, figs. $1-7$; pl. 11, figs. $4-$ 9.

\section{Material}

A total of 159 specimens from the Baddeckenstedt section, 5 specimens from the Söhlde section, 146 specimens from the Wunstorf Wu2010/1 core, and 88 specimens from the Wunstorf $\mathrm{Wu} 2010 / 3$ core.

\section{Remarks}

This study follows the intensively discussed generic affiliation of this species by Frieg and Kemper (1989).

\section{Occurrence}

Abundant to common in the lower Cenomanian and middle Cenomanian and rare to very rare in the upper Cenomanian.

Voloshinoides d'orbignyi (Reuss, 1845)

1845. Bulimina d'orbignyi Reuss, p. 38, pl. 13, fig. 74.
1937. Arenobulimina d'orbignyi (Reuss); Cushman, p. 39, pl. 4, figs. 9-12.

1969. Arenobulimina polonica Gawor-Biedowa, p. 90, pl. 6, fig. 3, pl. 8, figs. 5-8.

1982. Hagenowina d'orbignyi (Reuss); Frieg and Price, p. 70, pl. 2, 3, figs. n, o.

1989. Voloshinoides d'orbignyi (Reuss); Frieg and Kemper, p. 97, pl. 11, figs. 1-3.

\section{Material}

Nine specimens from the Baddeckenstedt section, two specimens from the Wunstorf Wu2010/1 core, and seven specimens from the Wunstorf Wu2010/3 core.

\section{Remarks}

This study follows the intensively discussed generic affiliation of this species by Frieg and Kemper (1989).

\section{Occurrence}

Very rare in the Cenomanian.

Family Cuneolinidae Saidova 1981

Subfamily Cuneolininae Saidova 1981

Genus Pseudotextulariella Barnard 1953

Pseudotextulariella cretosa (Cushman, 1932)

Fig. 8s

1932. Textulariella cretosa Cushman.

1989. Pseudotextulariella cretosa (Cushman); Frieg, p. 362, text-figs. 2 a-h, pl. 1, figs. 1-11.

\section{Material}

A total of 139 specimens from the Baddeckenstedt section, 1 specimen from the Söhlde section, 5 specimens from the Wunstorf Wu2010/1 core, 35 specimens from the Wunstorf Wu2010/3 core, and 4 specimens from the Wunstorf Wu2010/4 core.

\section{Remarks}

This species is used as index fossil for the Cenomanian of the English chalk (Hart et al., 1989), but Frieg (1989) already proved its existence in the lower part of the Albian. Our findings of four specimens in the middle Turonian of Wunstorf extends the stratigraphical range of this species and supports the idea of Frieg (1989) of a facies related appearance of Pseudotextulariella cretosa as it does not appear in the middle Turonian of Söhlde. 


\section{Occurrence}

Abundant to common in the lower and middle Cenomanian at Baddeckenstedt, rare to very rare in the Cenomanian and Turonian of Wunstorf, and absent in the Turonian of Söhlde.

Order Textulariida Delage and Hérouard 1896, emended Kaminski 2004

Suborder Textulariina Delage and Hérouard 1896

Superfamily Eggerelloidea Cushman 1937

Family Eggerellidae Cushman 1937

Subfamily Dorothiinae Balakhmatova 1972

Genus Marssonella Cushman 1933

Marssonella ozawai Cushman, 1936

Fig. 8u

1936. Marssonella ozawai Cushman, p. 43, pl. 4, figs. 10a, b. 1953. Marssonella ozawai Cushman; Barnard and Banner, p. 205, pl. IX, figs. 2A, B.

\section{Material}

A total of 42 specimens from the Baddeckenstedt section, 32 specimens from the Wunstorf Wu2010/1 core, and 11 specimens from the Wunstorf Wu2010/3 core.

\section{Occurrence}

Lower Cenomanian. Abundant at the sponge beds at Baddeckenstedt and at The Rib at Wunstorf, otherwise very rare.

Marssonella trochus (d'Orbigny, 1840)

1840. Textularia trochus d'Orbigny, 1840.

1953. Marssonella trochus (d'Orbigny); Barnard and Banner, 1953, p. 204, text-figs. 5o-s.

\section{Material}

Three specimens from the Söhlde section.

\section{Remarks}

Like suggested by Leary (1987), M. oxycona and M. turris are varieties of $M$. trochus.

\section{Occurrence}

Very rare.

Subfamily Pseudogaudryinae Loeblich and Tappan 1985
Genus Clavulinoides Cushman 1936

Clavulinoides sp.

\section{Material}

A total of 15 specimens from the Baddeckenstedt section and four specimens from the Söhlde section.

\section{Occurrence}

Very rare.

\section{Distribution of agglutinated foraminifers}

\subsection{Albian-Cenomanian boundary}

The Albian-Cenomanian boundary is only accessible in the Wunstorf Wu2010/1 core. It reaches from the base of the core towards the ultimus/Aucellina Event (Fig. 9). Significant groups are the tubular taxa Bathysiphon spp. and Nothia spp., coarsely grained globular taxa Psammosphaera fusca and Saccammina grzybowski, and elongate taxa Arenobulimina truncata, Bulbobaculites problematicus, Flourensina intermedia, Reophax subfusiformis, Tritaxia tricarinata, Vialovella frankei, and Voloshinoides advenus.

At a depth of $59.05 \mathrm{~m}$ the taxa Glomospira gordials, Repmanina charoides, and Tritaxia gaultina first occur. Below the ultimus/Aucellina Event at $54.8 \mathrm{~m}$ core depth, many taxa such as Ammodicsu glabratus, Ammolagena contorta, Gerochammina stanislawi, Glomospira diffundens, G. irregularis, Haplophragmoides eggeri, H. walteri, Pseudonodosinella parvula, P. troyeri, and Voloshinoides anglicus have their first occurrences.

The interval yields an increased proportion of straight tubular taxa, M1: $3.8 \%-33.6 \%$; shallow infaunal taxa M2a: $14.9 \%-20.6 \%$; and deep infaunal taxa M4b: 43.6\%-77.7\% (Fig. 9). It can be assigned to the low-latitude to mid-latitude slope biofacies proposed by Kuhnt et al. (1989). The diversity is moderate with Fisher alpha index values between 6.3 and 9.4 and SR values between 25 and 33 (Fig. 9).

\subsection{Cenomanian}

The Cenomanian agglutinated foraminiferal assemblage occurs from the ultimus/Aucellina Event up to the Facies Change below the CTBE (Figs. 9 to 11). The main faunal elements in the Baddeckenstedt section and Wunstorf Wu2010/1 and Wunstorf Wu2010/3 cores are the elongate taxa Arenobulimina truncata, Hagenowella elevata, Plectina cenomana, Tritaxia tricarinata, Vialovella frankei, and Voloshinoides advenus and the flattened irregular and attached Ammolagena clavata. In the southern Baddeckenstedt section more Eggerellina brevis and E. mariae occur, while in the Wunstorf cores additionally high numbers of Kadriayina gradata and Flourensina intermedia are seen. 


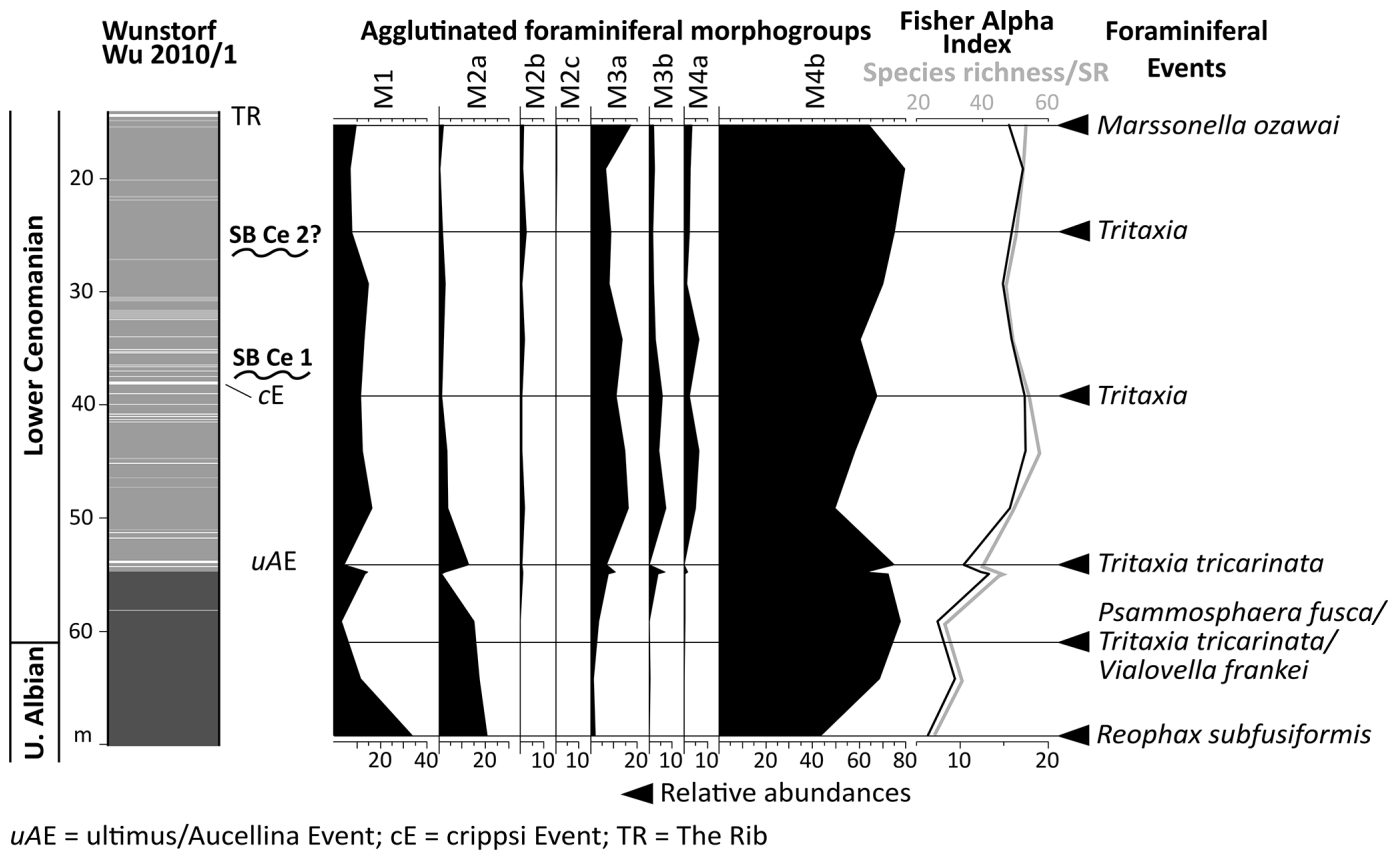

Figure 9. Columnar section of the Albian to Cenomanian part of the Wunstorf core Wu 2010/1 with agglutinated foraminiferal morphogroups, Fisher alpha index, species richness, and foraminiferal events (acmes) indicated by arrows. For log legend, see Fig. 3.

In the Wunstorf Wu2010/1 core, Hagenowella elevata, $H$. obesa, and Gaudryina sp. 1 first appear in the $u l$ timus/Aucellina Event at a core depth of $54.65 \mathrm{~m}$. At $49.05 \mathrm{~m}$ core depth, Voloshinoides d'orbignyi has its FO. Other FOs are notable at $44 \mathrm{~m}$ depth with Haplophragmoides aff. bubiki, H. suborbicularis, and Rectogerochammina eugubina. With the crippsi Event at $39 \mathrm{~m}$ core depth, Marssonella ozawai, Plectina cenomana, P. mariae, and Tritaxia macfadyeni occur for the first time in Wunstorf. Spiroplectammina navarroana appears and M. ozawai vanishes at $65.8 \mathrm{~m}$ core depth in the Wunstorf Wu2010/3 core above the marker limestone The Rib, while similar occurrences are notable in the Baddeckenstedt section shortly above marl MII. Other FOs at Baddeckenstedt are stateable with the appearance of Pseudonodosinella nodulosa at the primus Event and Haplophragmoides suborbicularis around the Mid-Cenomanian Event sensu Ernst et al. (1983). Pseudotextulariella cretosa vanishes below the Pycnodonte Event and Voloshinoides anglicus in the upper Cenomanian at $32 \mathrm{~m}$ in the Baddeckenstedt section.

In general, the Cenomanian agglutinated foraminiferal assemblages consist of extremely high relative abundances of the morphogroup M4b with values up to $95 \%$ and enhanced abundances of morphogroups M3a and/or M3b of up to $25 \%$ (Figs. 9 to 11). M1 values range between 10 and 20\%, M2a and M2b values are below 5\%, and M3b and M4a values reach up to $10 \%$ (Figs. 9 to 11). At Baddeckenstedt increased relative abundances of shallow infaunal living taxa (M3b) are noted, while at Wunstorf, numbers of epifaunal living taxa (M3a) are enhanced (Figs. 9 to 11). Furthermore, the rela- tive abundances of deep infaunal living taxa (M4b) are between 10\%-20\% higher at Baddeckenstedt than at Wunstorf (Figs. 9 to 11). The Fisher alpha index of the Cenomanian agglutinated foraminiferal assemblage fluctuates between 7.4 and 20 while SR values are between 39 and 61 (Figs. 9 to $11)$.

\subsection{Cenomanian-Turonian boundary interval}

This interval spans from the prominent Facies Change including the plenus Bed to above the Cenomanian-Turonian boundary (Figs. 12 and 13). The dominant taxon is Bulbobaculites problematicus with $40 \%-70 \%$ relative abundance. Other common taxa are Ammodiscus cretaceous, A. tenuissimus, Eobigenerina variabilis, and Repmanina charoides.

Several taxa vanish with the Facies Change. In the Söhlde section as also in the Wunstorf Wu2010/4 core, Kadriayina gradata, Plectina cenomana, and P. mariae have their last occurrences. While Pseudonodosinella troyeri, Vialovella frankei, Gaudryina sp. 1, and Voloshinoides anglicus already vanish below the Facies Change at Baddeckenstedt, V. frankei and Gaudryina sp. 1 have been recorded in the plenus Bed at Wunstorf, $P$. troyeri occurs last in the basal lower Turonian, and V. anglicus vanishes earlier at Wunstorf. The LO of Gaudryinopsis filiformis can be observed in the plenus Bed of the Söhlde section, while this species was not recorded in the Wunstorf Wu2010/4 core.

Foraminiferal assemblages of this interval yield increased relative abundances of morphogroup M4b with up to $88.8 \%$. At Wunstorf, increased relative abundances of M2c, e.g. 


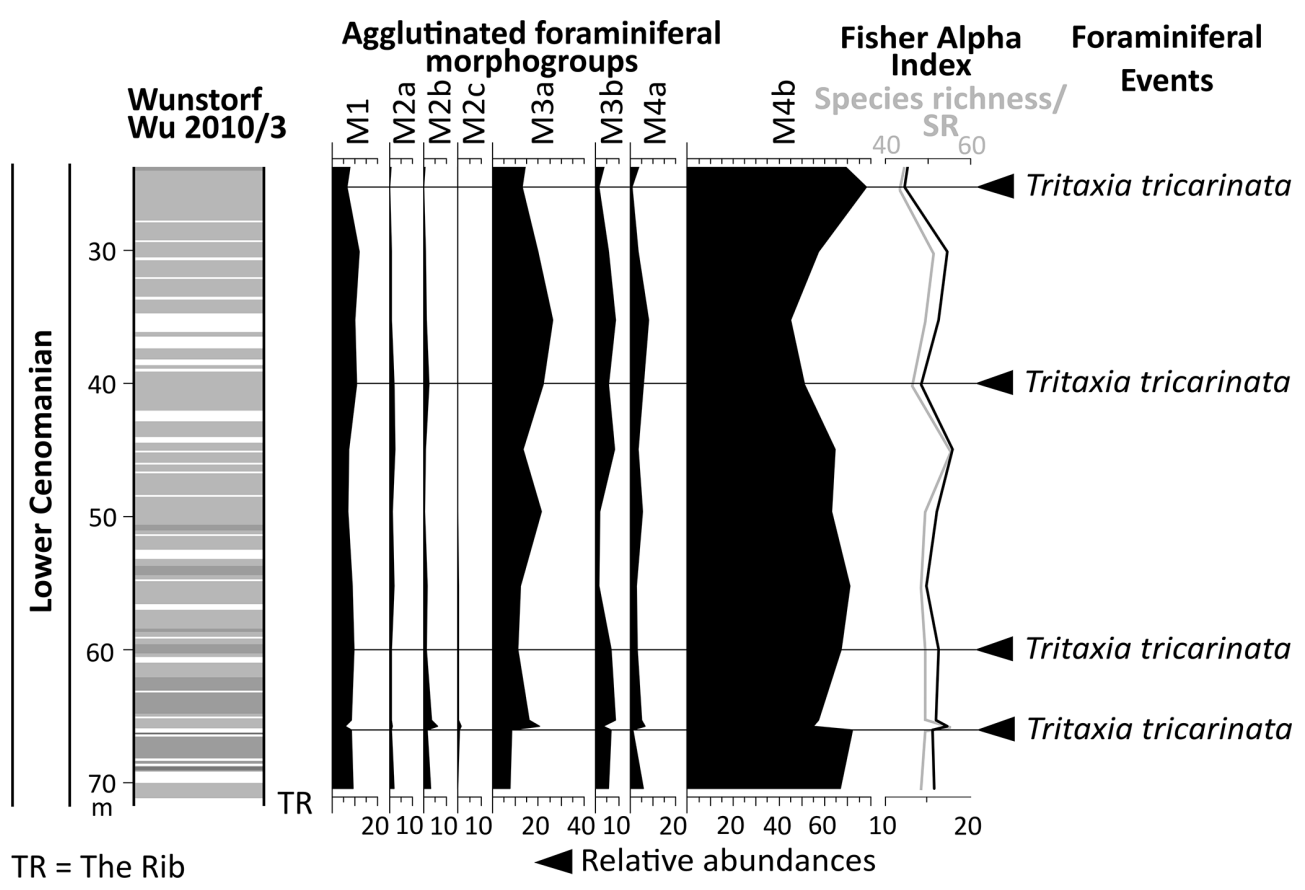

Figure 10. Columnar section of the Lower Cenomanian part of the Wunstorf core Wu 2010/3 with agglutinated foraminiferal morphogroups, Fisher alpha index, species richness, and foraminiferal events (acmes) indicated by arrows. For log legend, see Fig. 3.

Spiroplectammina navarroana, of up to $30.7 \%$ in the plenus Bed are recorded. The recorded diversity is low, between 4.1-6.2 Fisher alpha index, and there is a species richness between 18 and 25 (Figs. 12 and 13).

\subsection{Turonian}

In Turonian strata above the black shale-marlstone alternation of the Hesseltal Formation at Wunstorf (Fig. 12) and above the Cenomanian-Turonian boundary interval at Söhlde (Fig. 13), the species Ammolagena contorta, Arenobulimina preslii, A. truncata, Bulbobaculites problematicus, Gerochammina stanislawi, Hagenowella elevata, Repmanina charoides, and Spiroplectammina navarroana occur in high numbers ( $>5 \%$ relative abundances). In the Söhlde, additionally the elevated abundances of Ammobaculites agglutinans, Trochammina spp., and Trochamminoides spp. are notable.

While no FOs or LOs are recorded in the post-CTBE strata in Wunstorf, in Söhlde Ammosphaeroidina pseudopauciloculata, Gaudryinella irregularis, and Uvigerinammina jankoi occur first in the basal middle Turonian.

Above the black shale-marlstone alternation of the Hesseltal Formation, in deposits with slumping structures, high relative abundances of the morphogroup M4b (96.9\%) are noted at Wunstorf (Fig. 12). In strata of the Söhlde Formation, agglutinated foraminiferal assemblages are characterized by a medium high Fisher alpha index (12.19-15.94) and high species richness (45-49) at Wunstorf (Fig. 12). Relative abundances of the morphogroup M3a range between
$24.3 \%-34.1 \%$, while relative abundances of M4b between $40.7 \%-56.8 \%$ are noticed (Fig. 12). Above the CTBE, the Fisher alpha index rises towards 22.5 in the late Turonian of Söhlde, while species richness increases to 52 (Fig. 13). Relative abundances are recorded of morphogroup M3a between $8.6 \%-14.5 \%$, M3b between $7.4 \%-27.8 \%$, and M4b between 26-52.3 (Fig. 13).

\section{Stratigraphy}

\subsection{Lithostratigraphy and event stratigraphy}

The Wunstorf core Wu 2010/1 starts with 9 m of marly claystone (Fig. 4), which belongs to the uppermost Albian to lowermost Cenomanian Bemerode Member of the Herbram Formation (cf. Hiss et al., 2007a). The observed lithology matches that found nearby in the Anderten cores, covering the same sedimentation period (Bornemann et al., 2017). In proximal settings of central Europe, the transgressive $u l$ timus/Aucellina Event is used to determine the base of the Cenomanian (e.g. Ernst et al., 1983). However, the succession of Wunstorf is suggested to be more or less continuous due to a more distal position in an intrashelf depression. The following Cenomanian marl-limestone alternations of the Baddeckenstedt Formation (cf. Wilmsen and Hiss, 2007) are comparable to lithology of the Staffhorst shaft (Niebuhr et al., 1999), Konrad borehole (Niebuhr et al., 2001), Baddeckenstedt section (Wilmsen and Niebuhr, 2002), and Wunstorf quarry section (Wilmsen, 2003). 


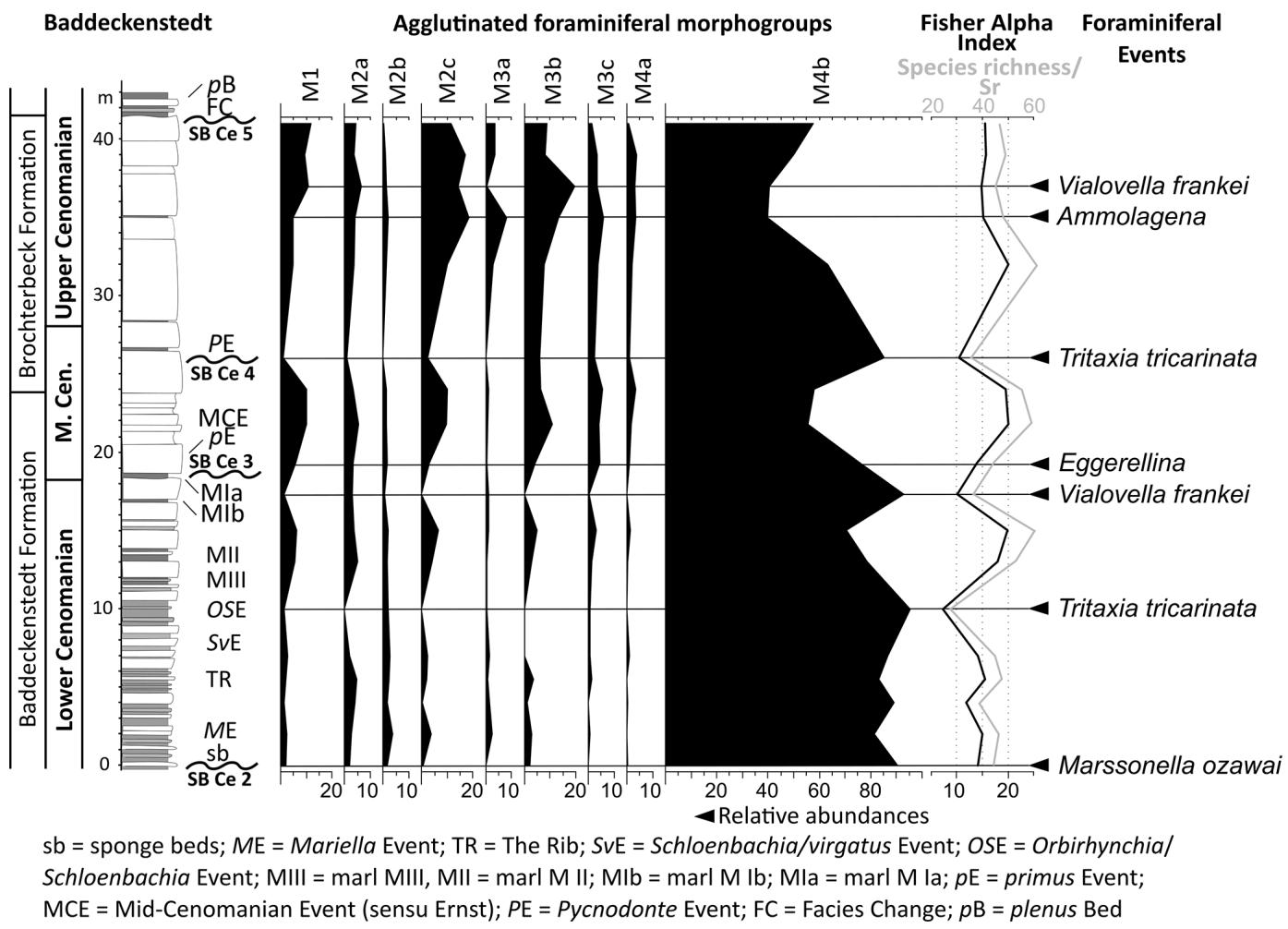

Figure 11. Columnar section of the Cenomanian part of the Baddeckenstedt quarry with agglutinated foraminiferal morphogroups, Fisher alpha index, species richness, and foraminiferal events (acmes) indicated by arrows. For log legend, see Fig. 3; log redrawn after Wilmsen (2003: Fig. 8).

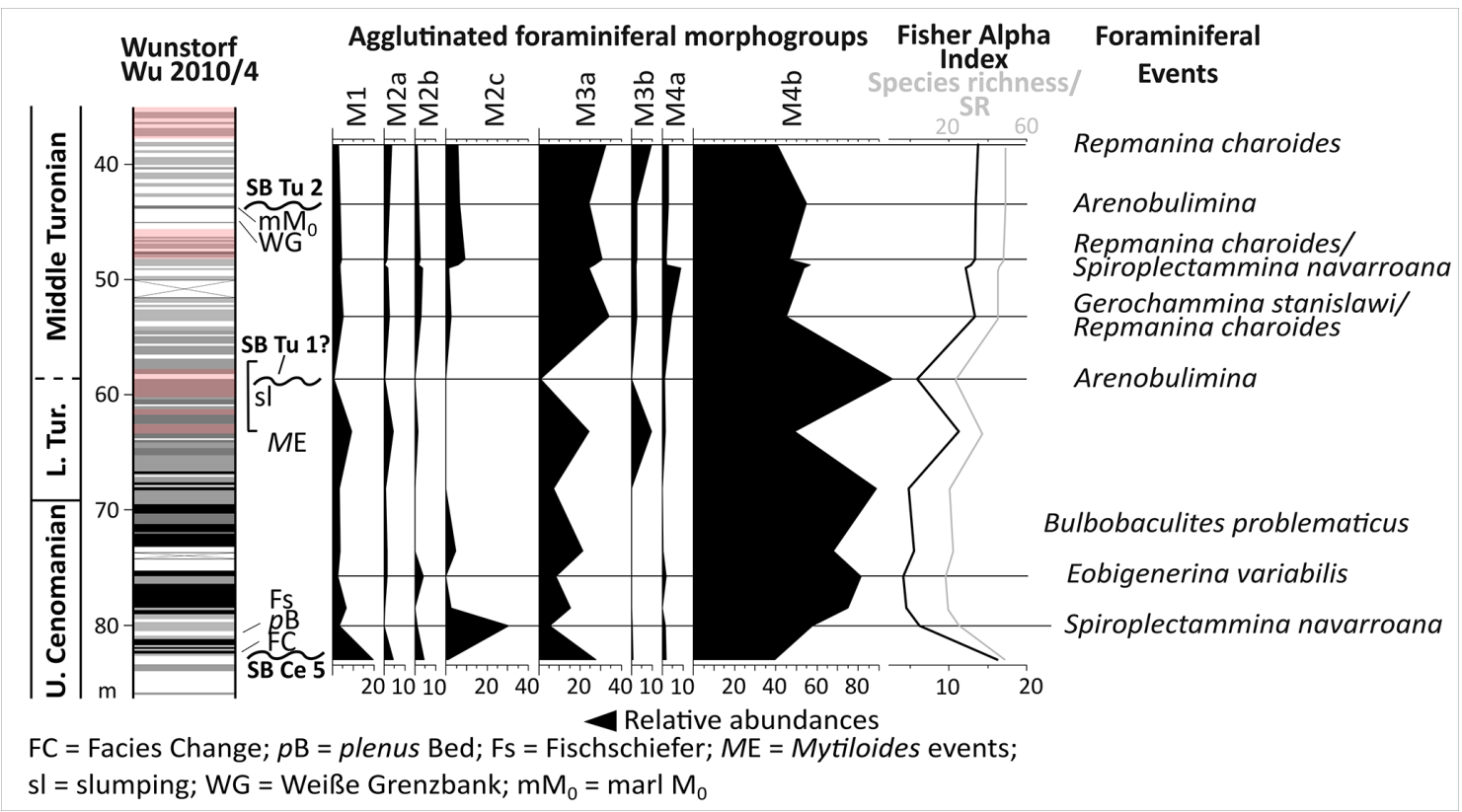

Figure 12. Columnar section of the Cenomanian-Turonian boundary and the Lower and Middle Turonian part of the Wunstorf core Wu 2010/4 with agglutinated foraminiferal morphogroups, Fisher alpha index, species richness, and foraminiferal events (acmes) indicated by arrows. For log legend, see Fig. 4. 


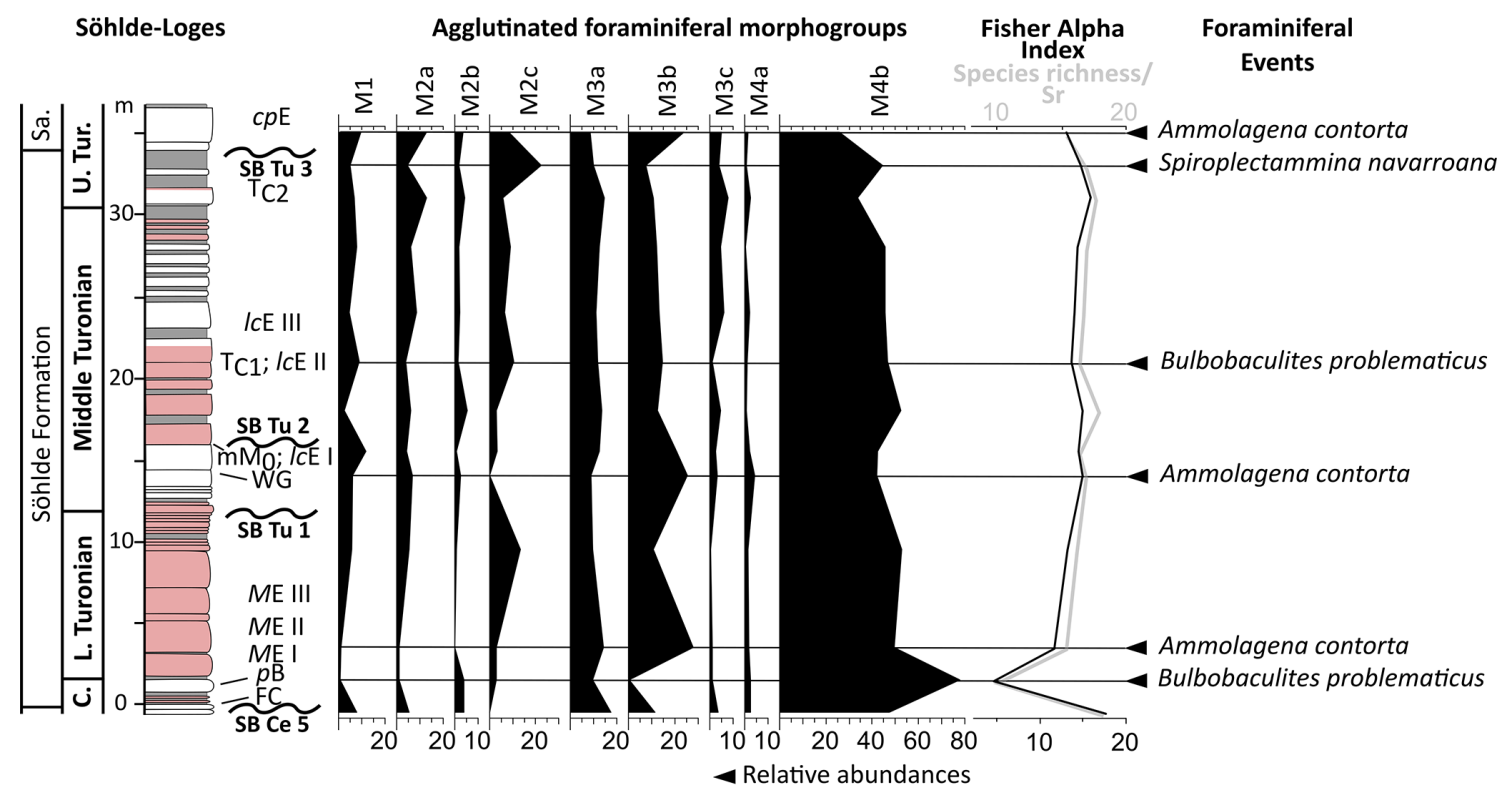

Sa. $=$ Salder Formation; FC = Facies Change; $p \mathrm{~B}=$ plenus Bed; $M \mathrm{IE} \mathrm{I}-\mathrm{III}=$ Mytiloides Event I-III; WG = Weiße Grenzbank; IcE I-III = lamarcki/cuvierii Event I-III; TC1 and TC2 = bentonite $\mathrm{T}_{\mathrm{C} 1}$ and $\mathrm{T} C 2 ; c p \mathrm{E}=$ costellatus/plana Event

Figure 13. Columnar section of the Cenomanian-Turonian boundary and the Lower to Upper Turonian part of the Söhlde-Loges quarry with agglutinated foraminiferal morphogroups, Fisher alpha index, species richness, and foraminiferal events (acmes) indicated by arrows. For log legend, see Fig. 4; log redrawn after Wiese (2009: Fig. 6).

The basal metres of the core Wunstorf Wu2010/4 (Fig. 5) are built by pure limestones of the Brochterbeck Formation (cf. Hiss et al., 2007b). Above the notable Facies Change, the black shale-marlstone alternation of the Hesseltal Formation (cf. Hiss et al., 2007c; see Voigt et al., 2008b) ranges from 82.5 to $63.5 \mathrm{~m}$ depth (Seibertz, 2013; Fig. 5). The recorded thickness is surprisingly low compared to other studies (e.g. Erbacher et al., 2007; Voigt et al., 2008b). About $12 \mathrm{~m}$ of Turonian strata is completely missing, likely induced by a prominent fault at $68 \mathrm{~m}$ core depth (Fig. 5). Above the Mytiloides events in strata belonging to the Söhlde Formation (cf. Wiese et al., 2007), slumping structures occur in the Wunstorf Wu2010/4 core (Seibertz, 2013; Fig. 5). Similar features were not recorded in previous studies on the nearby core Wunstorf WK1 (Voigt et. al, 2008b). Consequently, thicknesses can differ in between recorded Wunstorf cores, even at the regional scale, due to faults and slumping. The Weiße Grenzbank and the overlying marl $\mathrm{M}_{0}$ at around 44 to $46 \mathrm{~m}$ core depth (Seibertz, 2013; Fig. 5) can be correlated to the section Söhlde-Loges of Wiese (2009).

\subsection{Stable carbon isotopes}

The basal part of the studied stratigraphic sequence is expressed through the Albian-Cenomanian boundary interval (ACBI), which yields four distinct peaks of positive $\delta^{13} \mathrm{C}$ excursions: A to D, Fig. 4. A and B are not exposed in these samples; compare to Gale et al. (1996: Fig. 2). The AlbianCenomanian boundary (ACB), defined by the last occurrence
(LO) of the planktic foraminifer Thalmanninella globotruncanoides, is positioned between the stable carbon isotope excursions C and D (Kennedy et al., 2004; Bornemann et al., 2017). Comparable to the Anderten1 core (Bornemann et al., 2017) and the GSSP site Mont Risou (Gale et al., 1996), both stratigraphically higher excursions, C and D, are visible in the Wunstorf carbon isotope patterns and thus can be used to determine the Albian-Cenomanian boundary (Fig. 4). The following Lower Cenomanian events (LCE IIII) and the crippsi Isotope Event are weakly developed in the cores Wunstorf Wu2010/1 and Wunstorf Wu2010/3, respectively (Fig. 4). Bornemann et al. (2017) explain this weakly developed isotope events in the Lower Saxony basin with more continuous and only fewer condensed stratigraphical horizons than in the English Chalk.

The strong increase in $\delta^{13} \mathrm{C}$ values forming the Oceanic Anoxic Event 2 (OAE2) - Isotope Event (-IE; Jenkyns, 1980; Voigt et al., 2008b) is recorded in the Wunstorf Wu2010/4 core (Fig. 5). Above the OAE2-IE, a plateau of $\delta^{13} \mathrm{C}$ values like recorded in other studies can be recognized, but single known peaks are not observable (cf. Jarvis et al., 2006; Voigt et al., 2007, 2008b). The last peak on the plateau, similar to observations of Voigt et al. (2008b), is Tu 8, or the Round Down Event (Jarvis et al., 2006, Fig. 5). Afterwards $\delta^{13} \mathrm{C}$ values decrease (Fig. 5). An inflection point, from a slow decrease to a steep one, could not be found, and thus the position of the Low-woolgari Event of Jarvis et al. (2006) remains questionable. 


\subsection{Agglutinated foraminiferal biostratigraphy}

The Albian-Cenomanian boundary at Wunstorf is reflected by the first occurrence (FO) of the species Glomospira gordialis, Tritaxia gaultina, and Repmanina charoides. However, Tritaxia gaultina was reported from the Lower Cretaceous (Melinte-Dobrinescu et al., 2015) and Repmanina charoides (Kaminski and Gradstein, 2005; Józsa, 2017b; Józsa et al., 2018) and Glomospira gordialis (Józsa, 2017b, 2019) even from Jurassic strata. Many taxa such as some ammodiscids and arenobuliminids occur slightly above the stage boundary or at the Facies Change marked by the $u l$ timus/Aucellina Event at Wunstorf. Reported FOs by Frieg and Kemper (1989) and biozones by Hart et al. (1989) are in most cases not visible in the Wunstorf cores. Thus, Voloshinoides advenus already occurs in the latest Albian at Wunstorf while Frieg and Kemper (1989) reported it not until early Cenomanian times in northwest Germany (Fig. 14). Our observation fits more to those made by Hart et al. (1989, 2020), who report $V$. advenus already in the latest Albian. Arenobulimina preslii occurs with the $u l$ timus/Aucellina Event much earlier than usually found in the dixoni zone in northwest Germany (Frieg and Price, 1982; Frieg and Kemper, 1989; Fig. 14). Only some specimens of this species were found in the mantelli zone in the Münsterland (Frieg and Kemper, 1989). Furthermore, with the crippsi Event in Wunstorf or shortly above, the taxa Marssonella ozawai, Plectina cenomana, P. mariae, and Pseudotextulariella cretosa have their FO in Wunstorf (Fig. 14). While $M$. ozawai and P. cretosa are already known from the Albian (Frieg, 1989; Frieg and Kemper, 1989; Hart et al., 1989), P. mariae has been used to define the Albian-Cenomanian boundary in sections of the English Chalk (Hart et al., 1989; Hart and Fox, 2020; Fig. 14). P. cenomana otherwise reflects the Lower-Middle Cenomanian boundary in sections of the English Chalk (Hart et al., 1989) but occurs earlier in the Wunstorf cores (Fig. 14). FOs or LOs (first and last occurrences) commonly used for a stratigraphical division of the Cenomanian substages are not present in Wunstorf and Baddeckenstedt. With the Facies Change at the base of the OAE2 in the Lower Saxony Cretaceous, the Los of Kadriayina gradata, Flourensina intermedia, Plectina cenomana, and Voloshinoides advenus take place. Additionally, Vialovella frankei becomes extinct above the plenus Bed at Wunstorf (Fig. 14). This differs slightly from observations made in England, France, and other sections in Germany, in which $F$. intermedia (as F. mariae), P. cenomana, P. mariae, and $V$. advenus (as A. advena) taxa vanish in the plenus Bed (Carter and Hart, 1977, Hart et al., 1989; Fig. 14). These shorter stratigraphical ranges of some taxa from Lower Saxony could be caused by a stronger peculiarity of the periodical anoxic conditions in the sub-basins, which did not occur in most parts of the European shelf area. This is supported by the prolonged black shale deposition in Wunstorf (Voigt et al. 2008b), which likely affected other parts of the surrounding Lower Saxony Cretaceous sub-basins.

In the overlying Turonian strata, Ammosphaeroidina pseudopauciloculata, Gaudryinella irregularis, and Uvigerinammina jankoi have their FO in the middle Turonian in the Subhercynian Basin but not in the Wunstorf cores (Fig. 14). No comparable biostratigraphical information is available for G. irregularis while A. pseudopauciloculata does not appear until the Santonian as observed from sections in Italy (Kaminski et al., 2011). U. jankoi is the index taxon for the Turonian-Lower Campanian U. jankoi biozone in the western Tethys region (Geroch and Nowak, 1984; Coccioni et al., 1995; Kaminski et al., 2011) and in the Atlantic region (Kuhnt et al., 1989; Kuhnt and Kaminski, 1997). The FO recorded in Söhlde fits more to observations made in the western Tethys region (Fig. 14). Overall, in total ranges, FOs and LOs of agglutinated foraminifera are poorly applicable for the Albian to Turonian of Lower Saxony. The potential to correlate this qualitative data with other regions is suggested to be weak. The deep-water agglutinated foraminifera (DWAF) zonation from the North Atlantic and western Tethys is not fully applicable in all studied sections. Bulbobaculites problematicus represents the index taxon for the latest Albian to Cenomanian by Morgiel and Olszewska and Morgiel (1981). This correlates to observations from this study and differs from recorded zones of Geroch and Nowak (1984). The previous Plectorecurvoides alternans and latter Uvigerinammina jankoi Zone is not distinguishable in Wunstorf due to lack of the index taxa.

\section{Paleoenvironmental implications}

\subsection{Albian-Cenomanian boundary}

Due to a high number of infaunal and deep infaunal specimens (M4b, Fig. 9), but also increased relative abundances of filter feeding tubular living specimens (M1, Fig. 9), slightly eutrophic bottom water conditions can be assumed (Fig. 15) by applying the TROX model after Jorissen et al. (1995), van der Zwaan et al. (1999), and Setoyama et al. (2017). This is supported by a mass occurrence of the species Psammosphaera fusca, which commonly occurs in cold, nutrientrich deep-water habitats (Harloff and Mackensen, 1997). An acme of this species can be observed in Tethyan deepmarine environments of the same age (Melinte-Dobrinescu et al., 2015). Consequently, this supports the interpretation of Tyszka and Thies (2001) of a deep-water inflow from the Tethys Ocean towards the north via the Polish Trough during the Albian. A stressed environment, such as through seasonally dysaerobic conditions, possibly occurred in the latest Albian to earliest Cenomanian at Wunstorf indicated by increased relative abundances of $P$. fusca and Reophax. Large proportions of both fast-recolonizing taxa were described un- 


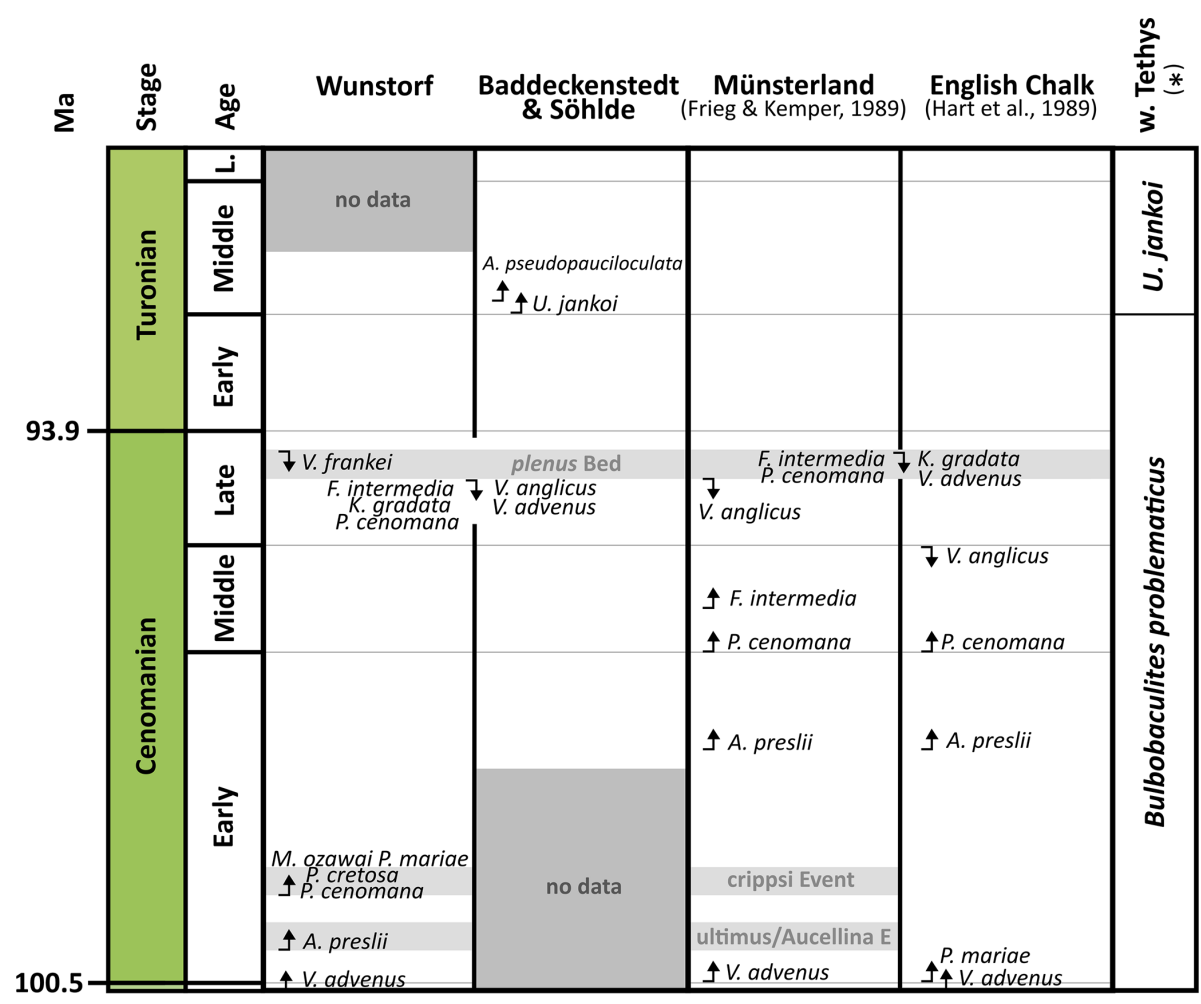

(*) - (Coccioni et al., 1995; Kaminski et al., 2011) $\quad$ ^ - FO $\quad$ - LO

Figure 14. Albian, Cenomanian, and Turonian FOs and LOs (first - and last occurrences) of selected agglutinated foraminifers from Lower Saxony (Wunstorf, Baddeckenstedt, Söhlde), the Münsterland (Frieg and Kemper, 1989) and the English Chalk (Hart et al., 1989), and the DWAF (deep-water agglutinated foraminifera) zonation of the western Tethys (Coccioni et al., 1995; Kaminski et al., 2011).

der a recent stressed environment from the Californian borderland basin by Kaminski et al. (1995).

\subsection{Cenomanian}

Following the TROX model (Jorissen et al., 1995; Van der Zwaan et al., 1999; Setoyama et al., 2017) bottom water conditions during the lower to middle Cenomanian time were mesotrophic to eutrophic (Fig. 15), indicated by a continuous record of morphogroup M1 and increased relative abundances of morphogroups M3a-M3b and M4b (Figs. 9 to 11). Rising relative abundances of shallow infaunal morphogroup M3a and epifaunal morphogroup M3b from below $5 \%$ in the lower Cenomanian to up to $20 \%$ in the upper Cenomanian (Figs. 9 to 11) are likely explained by a shift from more eutrophic to more mesotrophic conditions during the Cenomanian. This is in accordance with the lithological succession (e.g. rising carbonate content) and proposed sea level fluctuations by Wilmsen (2003) and Janetschke et al. (2015; Fig. 3). The food influx during the early to early-middle Cenomanian in the Lower Saxony and Subhercynian sub-basins was mainly controlled by fluvial inlet and so depended on the distance to the shore (Wilmsen, 2003). Higher relative abundances of deep infaunal morphogroup M4b at Baddeckenstedt (Fig. 11) are likely induced by the more proximal posi- tion of Baddeckenstedt (Fig. 1) and therefore a higher food supply.

At Wunstorf, about $7 \mathrm{~m}$ above the ultimus/Aucellina Event, morphogroup M4b relative abundances rapidly decrease (Fig. 9). This likely links to the prominent early Cenomanian transgression belonging to the Depositional Sequence Albian-Cenomanian 1, DS Al-Ce 1, which are described in detail at sections of the Lower Saxony Basin by Niebuhr et al. (1999, 2001), Wilmsen (2003, 2007), Bornemann et al. (2007), and Erbacher et al. (2020). A minimum of relative abundances of M4b in the Wunstorf Wu2010/1 core at a depth of $49.05 \mathrm{~m}$ (Fig. 9) likely reflects a low food supply, and therefore, the possible maximum flooding zone of DS Al-Ce 1 (Fig. 3). The crippsi Event at Wunstorf yields increased relative abundances of M4b (Fig. 9). This likely relates to a high food supply during the formation of the crippsi Event. Below the prominent limestone bed The Rib relative abundances of M4b are high (Fig. 9), which likely reflects high food availability at SB Ce 2 proposed by Wilmsen (2003). Low relative abundances of deep-infaunal taxa (M4b) at a depth of $35.2 \mathrm{~m}$ of the Wunstorf Wu2010/3 core (Fig. 10) are likely induced by low food supply and probably can be correlated to equally lower values above the marl MII of the Baddeckenstedt section (Fig. 11). This can not be re- 


\begin{tabular}{|c|c|c|c|c|c|c|}
\hline \multirow{6}{*}{$\frac{\frac{c}{\sqrt{0}}}{\frac{c}{2}}$} & \multirow{3}{*}{$\begin{array}{l}\frac{1}{2} \\
\frac{2}{2}\end{array}$} & $\begin{array}{l}\text { Depositional } \\
\text { sequences }\end{array}$ & Bioevents & Lower Saxony Basin & Subherzynian Subbasins & $\begin{array}{l}\text { Nutrient } \\
\text { regime }\end{array}$ \\
\hline & & \multirow[t]{2}{*}{ Tu 4} & & & & \\
\hline & & & ETB & & Ammolagena, S. navarroana & \\
\hline & \multirow{2}{*}{$\begin{array}{l}\frac{0}{0} \\
\frac{0}{\Sigma} \\
\Sigma\end{array}$} & Tu 3 & $\begin{array}{l}\text { MFB } \\
\text { ETB }\end{array}$ & $\begin{array}{c}\text { Repmanina charoides } \\
\text { Arenobulimina }\end{array}$ & Bulbobaculites problematicus & \\
\hline & & Tu 2 & $\begin{array}{l}\text { MFB } \\
\text { ETB }\end{array}$ & $\begin{array}{c}\text { Repmanina charoides } \\
\text { Arenobulimina }\end{array}$ & & \\
\hline & - & Ce-Tu 1 & MFB & Eobigenerina variabilis & Ammolagena contorta & \\
\hline \multirow{7}{*}{ 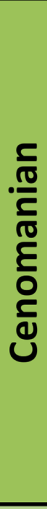 } & \multirow{5}{*}{$\begin{array}{l}\frac{0}{0} \\
\frac{0}{2} \\
\frac{1}{2}\end{array}$} & & ETB & B. problematicus, S. navarroana & Bulbobaculites problematicus & \\
\hline & & Ce 5 & $\begin{array}{l}\text { LHB } \\
\text { MFB } \\
\text { ETB }\end{array}$ & & $\begin{array}{l}\text { Vialovella frankei } \\
\text { Ammolagena }\end{array}$ & \\
\hline & & \multirow[b]{2}{*}{$\mathrm{Ce} 4$} & LHB & & & \\
\hline & & & $\begin{array}{r}\text { MFB } \\
\text { ETB }\end{array}$ & & Eggerellina brevis, Eggerellina mariae & \\
\hline & & $\mathrm{Ce} 3$ & $\begin{array}{l}\text { LHB } \\
\text { MFB } \\
\text { ETB }\end{array}$ & $\begin{array}{l}\text { Marssonella ozawai } \\
\text { Tritaxia tricarinata, Tritaxia gaultina }\end{array}$ & $\begin{array}{l}\text { Vialovella frankei } \\
\text { Tritaxia tricarinata } \\
\text { Marssonella ozawai }\end{array}$ & \\
\hline & \multirow{3}{*}{$\sum_{0}^{1}$} & Ce 2 & & & & \\
\hline & & \multirow[t]{2}{*}{ Al-Ce 1} & LHB & Tritaxia tricarinata, Tritaxia gaultina & & \\
\hline \multirow{3}{*}{$\frac{1}{\frac{10}{2}}$} & & & ETB & Tricarinata tricarinata & & \\
\hline & \multirow{2}{*}{$\begin{array}{l}\frac{1}{1} \\
\frac{2}{2}\end{array}$} & \multicolumn{5}{|c|}{$\begin{array}{l}\text { shaded dark grey }=\text { not exposed or not studied; shaded light grey }=\text { no significant mass-occurences } \\
\text { ETB = Early Transgression Bioevent; MFB = Maximum Flooding Bioevent; LHB = Late Highstand Bioevent }\end{array}$} \\
\hline & & eutrophic & & oligotrophic $\square$ & prolonged eutrophic conditions after $\mathrm{OA}$ & \\
\hline
\end{tabular}

Figure 15. Albian, Cenomanian, and Turonian micro-bioevents, their subtypes defined by agglutinated foraminifers, and interpreted bottomwater nutrient regimes in the Lower Saxony Cretaceous as well as in the Subhercynian subbasins. Micro-bioevent subtypes correlate with one or more acmes of specific agglutinated foraminiferal species. Depositional sequences and their stratigraphical relations are from Janetschke et al. (2015: Fig. 6).

lated to the maximum flooding zone of DS Ce 3, which was proposed to be below at the Schloenbachia/virgatus Event (Wilmsen, 2003, 2008). The Lower to Middle Cenomanian boundary at Baddeckenstedt exhibits a higher abundance of the morphogroup M4b (Fig. 11). This likely reflects high food availability at the SB Ce 3 proposed by Wilmsen (2003).

For the late-middle to late Cenomanian times, a shift to more oligotrophic conditions in the Lower Saxony basin due to a breakdown of a shelf-front system is proposed (Wilmsen, 2003). Following the paleoceanographical models by Linnert et al. (2010) and Püttmann and Mutterlose (2021), nutrients are mainly delivered by oceanic currents or are provided by mixing processes during stormy seasons (Linnert et al., 2010). Decreased relative abundances of deep infaunal taxa of morphogroup M4b during this time interval are likely induced by this lower food availability. Increased abundances of M4b during this interval are likely affected by regressional trends such as the periodical reinstallment of the shelf-front system or by enhanced vertical and lateral mixing of the water column during stormy seasons. Applying the TROX model to recorded foraminiferal assemblages, mesotrophic bottom water conditions during this interval (Fig. 15) but in general lower food availability than during the early to earlymiddle Cenomanian are assumed.

The strata, containing the Mid-Cenomanian Event sensu Ernst et al. (1983), yield a distinct decline in M4b relative abundance and high numbers of group M3a-M3b in Baddeckenstedt (Fig. 11). Wilmsen (2003) placed the maximum flooding zone of the DS Ce 4 exactly at this level. Decreased food availability during that interval is inferred based on the agglutinated foraminifers applying the TROX model established by Jorissen et al. (1995), van der Zwaan et al. (1999), and Setoyama et al. (2017).

The strata about $1 \mathrm{~m}$ below the Pycnodonte Event again yield high abundances of group M4b at Baddeckenstedt (Fig. 11). High food supply at the SB Ce 4 is likely. About $7 \mathrm{~m}$ above the Pycnodonte Event at Baddeckenstedt, decreased relative abundances of deep infaunal taxa (Fig. 11) likely indicate lower food availability. In consideration, the main food sources are likely currents from offshore or mixing due to stormy seasons, increasing water depth, and following lower nutrient influx or less stormy seasons. In the case of an increase in water depth, this interval likely reflects the maximum flooding zone of DS Ce 5 (Fig. 3). 
In general, the discussed time interval is characterized by bottom water conditions changing from eutrophicmesotrophic to clearly mesotrophic. This likely corresponds to the Cenomanian eustatic sea level rise (Fig. 3) stated by Haq et al. (1987) and Haq (2014).

\subsection{Cenomanian-Turonian boundary interval}

Low diverse agglutinated foraminiferal assemblages from the Cenomanian-Turonian boundary interval at Wunstorf and Söhlde indicate unfavourable living conditions. The dominance of infaunal to deep infaunal taxa and low diversities like recorded at Wunstorf and Söhlde (Figs. 12 and 13) are indicative for periodically anoxic bottom water conditions (cf. Kaminski et al., 1995). Eutrophic conditions are likely (Fig. 15), following the TROX model.

Bulbobaculites problematicus is the most dominant faunal component in this interval with relative abundances up to $70 \%$ (Figs. 12 and 13). Due to its high relative abundances, this taxon likely represents an opportunistic species, recolonizing after periodical bottom water anoxia or even tolerating lower oxygen concentrations in bottom waters. Spiroplectammina navarroana, a species usually known from deeper and thus colder habitats (Gradstein et al., 1999) occurs in the Wunstorf cores in an acme at the level of the plenus Bed with a relative abundance of $30 \%$ (Fig. 12). The acme likely represents a southward migration of cool-habitat-favouring fauna corresponding to findings of similar migration patterns of macrofaunal taxa by Gale and Christensen (1996). A similar acme is absent at Söhlde. This absence is likely explained by the southern migration of Spiroplectammina navarroana being limited in deeper habitats like at Wunstorf or by an extended hiatus at Söhlde.

\subsection{Turonian}

The middle Turonian and basal part of the upper Turonian bears relatively low abundances of the morphogroup M4b and comparably high abundances of the morphogroups M3a and/or M3b and medium high diversities (Figs. 12 and 13). This likely supports a shift to more oligotrophic bottom water conditions during the Turonian (Fig. 15). Assumptions made for surface water conditions in the Cretaceous shelf sea reflect a similar trend (Wiese et al., 2015).

In all sections, "Lazarus" species from the genera Ammodiscus, Glomospira, and Repmanina appear above the CTBE, comparable to observations in Tethyan deep-water carbonates, made by Coccioni et al. (1995) and Kaminski et al. (2011). The strata with slumping structures at Wunstorf contain high relative abundances of the morphogroup M4b (Fig. 12), which could reflect high food supply at the SB Tu 1 (Fig. 3) applying the TROX model by Jorissen et al. (1995), van der Zwaan et al. (1999), and Setoyama et al. (2017). Otherwise, these assemblages could be affected by instable environmental conditions due to strong redeposition of strata during this interval. At Söhlde a similar trend is not visible (Fig. 13).

Increased relative abundances of the morphogroup M4b above the Weiße Grenzbank at Söhlde and Wunstorf (Figs. 12 and 13) likely reflect higher food availability in the bottom water. This likely corresponds to the SB Tu 2 proposed by Janetschke et al. (2015; Fig. 3).

\section{Agglutinated foraminiferal biofacies}

The agglutinated foraminiferal fauna from the AlbianCenomanian boundary within the Herbram Formation is classified to be the low-latitude to mid-latitude slope biofacies as proposed by Kuhnt et al. (1989). In contrast to this, the recorded Cenomanian to Turonian agglutinated foraminiferal assemblages of the Lower Saxony Cretaceous are different including planktic, calcareous benthic foraminifers, and calcareous-cemented species, such as some Arenobulimina species, Tritaxia, and Eggerellina. Previously described assemblages of such a biofacies from Trinidad (Kaminski et al., 1988) and the Iberian Peninsula (Kuhnt and Kaminski, 1997) are mainly from the lower bathyal environments, whereas the Cenomanian successions from this study were deposited in shallower water depth below $100 \mathrm{~m}$ (Wilmsen, 2003). For the late-early Cenomanian, water depths of 20-30 m at Baddeckenstedt and ca. $50 \mathrm{~m}$ at Wunstorf are estimated by Wilmsen (2003). During the CTBE, water depths of 100-150 $\mathrm{m}$ at Wunstorf are assumed (Wilmsen, 2003). Subsequently, a new biofacies is proposed. The newly named mid-latitude shelf biofacies differs from others by higher relative abundances of up to $30 \%$ of taxa of morphogroups M3a and/or M3b, and up to $95 \%$ of morphogroup M4b, while the diversity is higher with Fisher alpha indices usually between 12 and 20 (Figs. 9 to 13). These assemblages indicate an upper bathyal to inner shelf setting.

\section{Agglutinated foraminiferal bioevents}

In the Cenomanian, three types of macro-bioevents occurred: early transgressive bioevents (ETBs), maximum flooding bioevents (MFBs), and late highstand bioevents (LHBs; Wilmsen, 2003, 2012). These bioevents are in accordance with sea-level-driven depositional sequences. ETBs form either due to winnowing fines and thus accumulation of resistant hard parts, called lag subtype, or due to migration events of uncommon or exotic taxa, called migration subtype. MFBs yield assemblages of taxa adapted to a low water energy, a low food supply, and often soft substrates (Wilmsen, 2003, 2012). LHBs occur as accumulated biogenic hard parts due to a reduced accumulation space at the end of a sea level highstand (Wilmsen, 2003, 2012). Similar bioevents, expressed through acmes, occur in the foraminiferal record of this research (Fig. 15). 
Below the ultimus/Aucellina Event, two acmes are recorded in the Wu2010/1 core, yielding high abundances of Reophax subfusiformis at $70 \mathrm{~m}$ core depth and Psammosphaera fusca, Tritaxia tricarinata, and Vialovella frankei at $62 \mathrm{~m}$ core depth (Figs. 9 and 15).

Synchronously to the ultimus/Aucellina Event in the Wunstorf 2010/1 core, high relative abundances of Tritaxia tricarinata are recorded (Figs. 9 and 15). This species has a thin test. A lag subtype is not plausible for this bioevent, because thin and fragile tests are likely destructed during accumulation of lag subtype bioevents proposed by Wilmsen (2003, 2012). Subsequently, this micro-bioevent is regarded to be a migration subtype ETB.

At the crippsi Event in the Wunstorf Wu2010/1 core, increased relative abundances of Tritaxia gaultina and T. tricarinata occur. They likely constitute the LHB of DS Al-Ce 1 as proposed for the crippsi Event by Wilmsen (2012) and Wilmsen et al. (2021).

A possible ETB of DS Ce 3 with high amounts of the species Marssonella ozawai occurs below the Mariella Event at Baddeckenstedt (Figs. 11 and 15). In the Wunstorf Wu2010/1 core, an acme of the genus Tritaxia is observed below The Rib (Figs. 9 and 15). Fragile tests of the genera Marssonella and Tritaxia, which commonly break during transgressive reworking, support the interpretation as migration subtype bioevents.

In the Wunstorf Wu2010/3 core, increased relative abundances of Marssonella ozawai and Pseudonodosinella nodulosa occur above The Rib; in the Baddeckenstedt section an acme of Tritaxia tricarinata is situated at the level of the Orbirhynchia/Schloenbachia Event (Figs. 10, 11, and 15). This position represents a maximum flooding interval (Wilmsen, 2008). Following the model by Wilmsen (2012), these taxa with acmes are supposed to be specialists for environmental conditions during maximum flooding, e.g. lower food supply and soft substrate.

Increased relative abundances of Vialovella frankei in the Baddeckenstedt section above the marl MIb likely represent a LHB (Figs. 11 and 15).

Eggerellina has an acme at the level of the primus Event in the Baddeckenstedt section (Figs. 11 and 15). The occurrence of this thin-shelled taxon likely indicates a migration subtype ETB of DS Ce 4 as well as proposed for the primus Event by Wilmsen et al. (2007).

Below the Pycnodonte Event, an acme of T. tricarinata occurs in the Baddeckenstedt section (Fig. 11; Table 2). While the Pycnodonte Event is classified as a lag subtype ETB (Wilmsen and Voigt, 2006; Wilmsen, 2012), thin-shelled tests of recorded foraminifer species suggest a migration subtype ETB.

An acme of Ammolagena in the Baddeckenstedt section (Figs. 11 and 15) probably correlates to the Amphidonte Event, which is regarded to be the MFB in the DS Ce 5 (Wilmsen, 2012). Thus, encrusting Ammolagena is likely adapted to more oligotrophic bottom water conditions.
A possible LHB shortly above the Amphidonte Event is expressed by an acme of $V$. franke $i$ at Baddeckenstedt (Figs. 11 and 15).

During the interval of the CTBE, Bulbobaculites problematicus occurs with high relative abundances of usually more than $30 \%$, and Spiroplectammina navarroana has an acme in the plenus Bed in the Wunstorf 2010/4 core (Figs. 12 and 15). These taxa are uncommon for the older strata; thus, they are regarded to be exotic taxa. They likely represent migration subtype bioevents.

As a possible MFB, Eobigenerina variabilis appears in high numbers in the Wunstorf Wu2010/4 core, and Ammolagena contorta appears at Söhlde (Figs. 12, 13, and 15). These taxa likely prefer more oligotrophic bottom water conditions.

Increased relative abundances of different species of Arenobulimina in the Wunstorf Wu2010/4 core (Figs. 12 and 15) likely represent the ETB of the DS Tu 2 proposed by Janetschke et al. (2015). As these taxa have relatively robust tests, a lag subtype ETB induced by the accumulation of resistant hard parts during transgressive reworking as proposed by Wilmsen, 2012) is likely. Otherwise, the recorded interval at Wunstorf is characterized by strong redeposition of strata, which could have influenced the recorded foraminiferal fauna.

Above this interval, an acme of Repmanina charoides with Gerochammina stanislawi and Spiroplectammina navarroana is observed in the Wunstorf Wu2010/4 core (Figs. 12 and 15). This acme likely represents the MFB of Ds Tu 2 proposed by Janetschke et al. (2015). $R$. charoides likely prefers more oligotrophic bottom water conditions as observed in the recent Mediterranean by De Rijk et al. (2000) and interpreted for Cretaceous to Paleogene foraminiferal assemblages by Setoyama et al. (2017).

Robust arenobuliminid tests occur in huge amounts slightly above marl M0 in the Wunstorf Wu2010/4 core (Figs. 12 and 15), which is likely to be the ETB of DS Tu 3 by Janetschke et al. (2015).

Another acme of Repmanina charoides above the marl M0 in the Wunstorf Wu2010/4 core (Figs. 12 and 15) likely represents MFB of DS Tu 3. Again, enhanced relative abundances of $R$. charoides likely indicate more oligotrophic bottom water conditions.

High numbers of Bulbobaculites problematicus occur in the Söhlde section around the lamarcki-cuvierii Event II (Figs. 13 and 15). This acme likely represents a MFB of DS Tu 3 by Janetschke et al. (2015). Furthermore, increased relative abundances of Spiroplectammina navarroana and Ammolagena are recognizable in the basal late Turonian of the Söhlde section (Figs. 13 and 15), probably marking a migration subtype bioevent likely related to the ETB of DS Tu 4 by Janetschke et al. (2015). Assigned to colder habitats (Gradstein et al., 1999) this acme of $S$. navarroana is possibly referred to the ongoing Late Turonian Cooling Event proposed by Voigt and Wiese (2000) and Wiese and Voigt (2002). 


\section{Conclusions}

Agglutinated foraminiferal assemblages have been studied from the Albian to Turonian deposits of the European shelf in northern Germany. With respect to assemblage compositions, we propose a new biofacies called the mid-latitude shelf biofacies, clearly differing in relative abundances from other contemporaneous sections. The main faunal elements of this biofacies are typical shelf-related elongate morphogroups such as Dorothia, Marssonella, Tritaxia, and arenobuliminids which appear to be the dominant-group epifaunal deepwater agglutinated foraminifera taxa either free living or attached living and tubular forms. Differences in their relative abundances are likely related to oxygen content dissolved in bottom waters which is mostly related to food supply.

1. Increased relative abundances of deep infaunal morphogroups during the latest Albian to early-middle Cenomanian reflect a relatively higher food supply, while decreased ones indicate lower food availability. As the main food source during this time interval is riverine inlet from the coast, maxima of relative abundances of deep infaunal morphogroups likely indicate low relative water depth, and minima probably are related to maximum flooding intervals.

2. Increased relative abundances of deep infaunal morphogroups due to a relatively high food availability during the early-middle Cenomanian to Turonian likely reflect stronger vertical mixing during stormy seasons as the main food source is currents from offshore.

3. In proximal settings the relative abundances of deep infaunal morphogroups are higher than recorded in distal positions, which indicates a higher food supply in proximal settings. Proximal foraminiferal assemblages contain higher numbers of attached epifaunal morphogroups while in distal positions free epifaunal taxa occur more often.

4. Strata deposited during intervals of periodical anoxia at the bottom water layers such as related to the OAE2, or during strong synsedimentary redeposition of sediment mostly linked to tectonic events as recorded in parts of the Turonian at Söhlde and at Wunstorf, contain low diverse foraminiferal assemblages. These are composed of mainly deep infaunal taxa such as Bulbobaculites problematicus.

While macro-bioevents are one of the most important features of the often-applied event stratigraphy, these events are also reflected by microfossils such as agglutinated foraminifers.

Data availability. Data related to this study are provided in the Supplement.
Supplement. The supplement related to this article is available online at: https://doi.org/10.5194/fr-24-395-2021-supplement.

Author contributions. RMB collected all samples and studied the agglutinated foraminiferal assemblages. US performed the lab analysis of stable carbon isotopes. ES studied the lithology of the Wunstorf cores and provided the event stratigraphic scheme. All authors wrote and edited the manuscript as well as edited the figures.

Competing interests. The contact author has declared that neither they nor their co-authors have any competing interests.

Disclaimer. Publisher's note: Copernicus Publications remains neutral with regard to jurisdictional claims in published maps and institutional affiliations.

Acknowledgements. First, we would like to thank Birgit Niebuhr (Dresden) for a lot of effort in discussing and improving this study. Tobias Püttmann (Krefeld) and Štefan Józsa (Bratislava) provided constructive reviews that we highly appreciate and substantially improved this paper. We appreciate the possibility of access to the Wunstorf cores provided by Bernd-Henning Reupke (Hannover) and the Holcim (Deutschland) GmbH Höver and access to the working quarry in Söhlde given by the Loges Kalk- und Kreidewerk. We thank Benjamin Besen and Patrick Göhring (both Hildesheim) for their assistance in the field, Edina Merdan (Berlin) for help in core sampling and digital imaging, and Jan Evers (Berlin) to support the photography of foraminifers. Finally, we would like to thank Florian Witzmann (Berlin) for the professional editorial work.

Review statement. This paper was edited by Florian Witzmann and reviewed by Tobias Püttmann and Stefan Jozsa.

\section{References}

Alegret, L. and Thomas, E.: Upper Cretaceous and lower Paleogene benthic foraminifera from northeastern Mexico, Micropaleontology, 47, 269-316, 2001.

Badaye, H.: Multistratigraphische Untersuchungen im Cenoman und Turon des Lichtenberger Höhenzuges unter besonderer Berücksichtigung der Kalkbrüche Baddeckenstedt und GroßElbe, Diploma thesis, Freie Univ. Berlin, 117 pp., 1986.

Bąk, K.: Biostratigraphy of deep-water agglutinated Foraminifera in Scaglia Rossa-type deposits of the Pieniny Klippen Belt, Carpathians, Poland, in: Proceedings of the Fifth International Workshop on Agglutinated Foraminifera, edited by: Hart, M. B., Kaminski, M. A., and Smart, C. W., Grzybowski Found. Spec. Publ., 7, 15-41, 2000.

Bąk, K.: Deep-water facies succession around the CenomanianTuronian boundary in the Outer Carpathian basin: Sedimentary, biotic and chemical records in the Silesian Nappe, Poland, Palaeogeogr. Palaeocl., 248, 255-290, 2007. 
Bąk, K., Bąk, M., Geroch, S., and Manecki, M.: Biostratigraphy and paleoenvironmental analysis of benthic foraminifera and radiolarians in Paleogene variegated shales in the Skole unit, Polish Flysch Carpathians, Ann. Soc. Geol. Pol., 67, 135-154, 1997.

Barnard, T. and Banner, F. T.: Arenaceous Foraminifera from the Upper Cretaceous of England, Q. J. Geol. Soc., 109, 173-216, 1953.

Bartenstein, H.: Taxonomische Bemerkungen zu den Ammobaculites, Haplophragmium, Lituola und verwandten Gattungen, Senckenbergiana, 33, 313-342, 1952.

Berggren, W. A. and Kaminski, M. A.: Abyssal Agglutinates: Back to Basics, in: Paleoecology, Biostratigraphy, Paleoceanography and Taxonomy of Agglutinated Foraminifera, edited by: Hemleben, C., Kaminski, M. A., Kuhnt, W., and Scott, D. B., NATO ASI Series C327, Kluwer Acad. Pub., 53-76, 1990.

Berry, E. W.: The smaller foraminifera of the middle Lobitos shales of northwestern Peru, Ecl. Geol. Helvetiae, 21, 390-405, 1928.

Berthelin, M.: Mémoire sur les foraminifères fossiles de l'étage Albien de Montcley (Doubs), Mém. Soc. Géol. France, 3éme Sér, 1, 85 pp., 1880.

Blumenberg, M. and Wiese, F.: Imbalanced nutrients as triggers for black shale formation in a shallow shelf setting during the OAE 2 (Wunstorf, Germany), Biogeosciences, 9, 4139-4153, https://doi.org/10.5194/bg-9-4139-2012, 2012.

Bornemann, A., Erbacher, J., Heldt, M., Kollaske, T., Wilmsen, M., Lübke, N., Huck, S., Vollmar, N. M., and Wonik, T.: The Albian-Cenomanian transition and Oceanic Anoxic Event 1d an example from the Boreal Realm, Sedimentology, 64, 44-65, https://doi.org/10.1111/sed.12347, 2017.

Brady, H. B.: On Saccammina Carteri, a new Foraminifer from the Carboniferous limestone of Northumberland, Ann. Mag. Natur. Hist. Ser., 4, 177-184, 1871.

Brady, H. B.: Notes on some of the reticularian Rhizopoda of the "CHALLENGER" Expedition; Part 1. On new or little known Arenaceous types, Q. J. Micropal. Sci., 19, 20-67, 1879.

Brady, H. B.: Report on the Foraminifera dredged by H. M. S. Challenger during the years 1873-1876, London, Rep. Sci. Res. Challenger Zool., 9, 814 pp., 1884.

Brotzen, F.: Foraminifera aus dem schwedischen untersten Senon von Eriksdal in Schonen, Sverige Geol. Unders. Ser. C, 396, 1206, 1936.

Bubík, M.: Cretaceous to Paleogene agglutinated foraminifera of the Bílé Karpaty unit (West Carpathians, Czech Republic), in: Proc. Fourth Internat. Worksh. agglt. Foram., edited by: Kaminski, M. A., Geroch, S., and Gasinski, M. A., Grzybowski Found. Spec. Publ., Ljubljana, 3, 71-116, 1995.

Bubík, M.: Remarks on the quantitative analysis of deep-sea agglutinated foraminiferal taphocoenoses with special attention to tubular astrorhizids, Micropaleontology, 65, 63-74, 2019.

Carsey, D. O.: Foraminifera of the Cretaceous of central Texas, Univ. Texas Bull., 2612, 56 pp., 1926.

Carter, D. J. and Hart, M. B.: Aspects of mid-Cretaceous stratigraphical micropalaeontology, Bull. Brit. Mus. Natur. Hist., 29, 135 pp., 1977.

Cetean, C. G., Bălc, R., Kaminski, M. A., and Filipescu, S.: Integrated biostratigraphy and palaeoenvironments of an upper Santonian-upper Campanian succession from the southern part of the Eastern Carpathians, Romania, Cret. Res., 32, 575-590, https://doi.org/10.1016/j.cretres.2010.11.001, 2011.
Chapman, F.: Microzoa from the Phosphatic Chalk of Taplow, Quart. J. Geol. Soc., 48, 514-518, 1892.

Charnock, M. A. and Jones, R. W.: Agglutinated foraminifera from the Paleogene of the North Sea, in: Paleoecology, biostratigraphy, paleoceanography and taxonomy of agglutinated foraminifera, edited by: Hemleben, C., Kaminski, M. A., Kuhnt, W., and Scott, D. B., NATO ASI Ser. C327, Kluwer Acad. Publ., Tübingen, 139-244, 1990.

Coccioni, R., Galeotti, S., and Gravili, M.: Latest Albian-earliest Turonian deep-water agglutinated foraminifera in the Bottaccione section (Gubbio, Italy), Biostratigraphic and palaeoecologic implications, Rev. Esp. Paleontl., 10, 135-152, 1995.

Cushman, J. A.: Textularia and related forms from the Cretaceous, Cont. Cushman Lab. Foram. Res., 8, 86-96, 1932.

Cushman, J. A.: The generic position of "Cornuspira cretacea Reuss”, Cont. Cushman. Lab. Foram. Res., 10, 44-47, 1934.

Cushman, J. A.: New genera and species of the families Verneuilinidae and Valvulinidae and of the subfamily Virgulininae, Cushman Lab. For. Res. Spec. Pub., 6, 1-71, 1936.

Cushman, J. A.: A monograph of the foraminiferal family Verneuilinidae, Cushman Lab. Foram. Res. Spec. Publ., 8, 1210, 1937.

Cushman, J. A. and Jarvis, P. W.: Cretaceous foraminifera from Trinidad, Cont. Cushman Lab. Foram. Res., 4, 85-103, 1928.

Cushman, J. A. and Renz, H. H.: The foraminiferal fauna of the Lizard Springs formation of Trinidad, British West Indies, Cushman Lab. Foram. Res. Spec. Publ., 18, 1-48, 1946.

Deeke, W.: Die Foraminiferenfauna der Zone des Stephanoceras humphriesianum im Unter-Elsass, Abh. Geol. Spez.-Kt. Els.Lothr., 4, 1-68, 1884.

De Montfort, P. D.: Conchyliologie systématique et classification méthodique des coquilles, Vol. 1, Schoell, Paris, 409 pp., 1808.

De Rijk, S., Jorissen, F. J., Rohling, E. J., and Troelstra, S. R.: Organic flux control on bathymetric zonation of Mediterranean benthic foraminifera, Mar. Micropaleontol., 40, 151-166, 2000.

d'Orbigny, A.: Paléontologie française: Description zoologique et géologique de tous les animaux mollusques et rayonnés fossiles de France, Terrains crétacés. mollusques céphalopodes, Cosson Paris, 696 pp., 1840

d'Orbigny, A.: Die fossilien Foraminiferen des tertiären Beckens von Wien, entdeckt von seiner Excellenz Ritter Joseph von Hauer, Gide et Comp. Paris, 412 pp., 1846.

d'Orbigny, A.: Prodrome de paléontologie stratigraphique universelle des animaux mollusques et rayonnés faisant suite au cours élémentaire de paléontologie et de géologie stratigraphiques, Masson Paris, 1, 394 pp., 2, 427 pp., 3, 389 pp., 1850-1852.

Dylążanka, M.: Warstwy inoceramowe z łomu w Szymbarku koło Gorlic. Roc. Pol. Tow. Geol., 1, 36-80, 1923.

Earland, A.: Foraminifera, Part 2. South Georgia, Disc. Rep., 7, 29 138, 1933.

Erbacher, J., Mutterlose, J., Wilmsen, M., and Wonik, T.: The Wunstorf Drilling Project: coring a global stratigraphic reference section of the Oceanic Anoxic Event 2, Sci. Drill., 4, 19-21, 2007.

Erbacher, J., Bornemann, A., Petrizzo, M. R., and Huck, S.: Chemostratigraphy and stratigraphic distribution of keeled planktonic foraminifera in the Cenomanian of the North German Basin, Z. Dt. Ges. Geowiss., 2, 1-13, https://doi.org/10.1127/zdgg/2020/0211, 2020. 
Ernst, G. and Rehfeld, U.: Transgressive development in the Early Cenomanian of the Salzgitter area (northern Germany) recorded by sea level controlled eco- and litho-events, Freiberger Forsch.H., 468, 79-107, 1997.

Ernst, G. and Rehfeld, U.: Cenomanian-Turonian of Baddeckenstedt, in: Key localities of the Northwest European Cretaceous, Mutterlose, edited by: J., Bornemann, A., Rauer, S., Spaeth, C., and Wood, C. J., Bochumer Geol. Geotechn. Arb., 48, 91-94, 1998.

Ernst, G. and Wood, C. J.: Die tiefere Oberkreide des subherzynen Niedersachsens, Terra Nostra, 5, 41-84, 1995.

Ernst, G. and Wood, C. J.: Söhlde quarries, in: Cretaceous Depositional Environments of NW Germany, edited by: Mutterlose, J., Wippich, M. G. E., Geisen, M., and Geisen, M., Bochumer Geol. Geotechn. Arb., 46, 55-61, 1997.

Ernst, G., Schmid, F., Seibertz, E., and Wood, C.: EventStratigraphie im Cenoman und Turon von NW-Deutschland, Zitteliana, 10, 531-554, 1983.

Ernst, G., Niebuhr, B., Wiese, F., and Wilmsen, M.: Facies development, basin dynamics, event correlation and sedimentary cycles in the Upper Cretaceous of selected areas of Germany and Spain, in: Global and regional controls on biogenic sedimentation, Part II, edited by: Reitner, J., Neuweiler, F., and Gunkel, F., Cretaceous sedimentation, Göttinger Arb. zur Geol. und Paläont., 3, 87-100, 1996.

Ernst, G., Wood, C. J., and Rehfeld, U.: Cenomanian-Turonian of Söhlde, in: Key Localities of the Northwest European Cretaceous, Mutterlose, edited by: J., Bornemann, A., Rauer, S., Spaeth, C., and Wood, C. J., Bochumer Geol. Geotechn. Arb., 48, 102-120, 1998.

Fenner, J., Bruns, A., Cepek, P., Köthe, A., Owen, H. G., Prauss, M., Riegel, W., Thies, A., Tyszka, J., Weiß, W., and Wiedmann, J.: Palaeontological results from the Boreal Albian (Cores Kirchrode I and II), biostratigraphy, palaeoenvironment and cycle analysis, in: Global and regional controls on biogenic sedimentation, edited by: Reitner, J., Neuweiler, F., and Gunkel, F., Göttinger Arb. Geol. Paläont., 3, 5-12, 1996.

Fisher, R. A., Corbet, A. S., and Williams, C. B.: The relation between the number of species and the number of individuals in a random sample of an animal population, J. Ani. Eco., 12, 42-58, 1943.

Franke, A.: Die Foraminiferen der Oberen Kreide Nord-und Mitteldeutschlands, Abh. Preuß. Geol. Landesanst., 111, 1-207, 1928.

Frentzen, K.: Die agglutinierenden Foraminiferen der Birmensdorfer Schichten (Transversarius-Zone in Schwammfazies) des Gebietes um Blumberg in Baden, Paläont. Z., 23, 317-343, 1944.

Frenzel, P.: Die benthischen Foraminiferen der Rügener Schreibkreide (Unter-Maastricht, NE-Deutschland), Neue Pal. Abh., 3, 361 pp., 2000.

Frieg, C.: Neue Ergebnisse zur Systematik sandschaliger Foraminiferen im Cenoman des südwestlichen Münsterlandes, Paläont. Z., 54, 225-240, 1980.

Frieg, C.: Über das Auftreten und den Kammerbau der Foraminifere Pseudotextulariella cretosa (CUSHMAN) in Nordwestdeutschland, Geol. Jb., 113, 359-371, 1989.

Frieg, C. and Kemper, E.: Mikropaläontologische Gliederung und Abgrenzung von Ober-Alb und Unter-Cenoman in Nordwestdeutschland, Geol. J., 113, 73-193, 1989.
Frieg, C. and Price, R. J.: The subgeneric classification of Arenobulimina, in: Aspects of Micropalaeontology, edited by: Banner, F. T. and Lord, A. R., George Allen and Unwin, 42-80, 1982.

Fuchs, W.: Eine alpine Foraminiferenfauna des tieferen MittelBarreme aus den Drusbergschichten vom Ranzenberg bei Hohenems in Vorarlberg (Österreich), Abh. Geol. Bundesanst., 27, 1-49, 1971.

Gale, A. and Christensen, W. K.: Occurrence of the belemnite Cenomanian of SE France and its significance, Bull. Geol. Soc. Denmark, 43, 68-77, 1996.

Gale, A., Kennedy, W., Burnett, J., Caron, M., and Kidd, B.: The Late Albian to Early Cenomanian succession at Mont Risou near Rosans (Drôme, SE France): an integrated study (ammonites, inoceramids, planktonic foraminifera, nannofossils, oxygen and carbon isotopes), Cret. Res., 17, 515-606, https//https://doi.org/10.1006/cres.1996.0032, 1996.

Gawor-Biedowa, E.: The genus Arenobulimina Cushman from the Upper Albian and Cenomanian of the Polish lowlands, Ann. Soc. Geol. Pol., 39, 73-102, 1969.

Gawor-Biedowa, E.: The Albian, Cenomanian and Turonian foraminifers of Poland and their stratigraphic importance, Acta Palaeont. Pol., 17, 3-183, 1972.

Geroch, S. and Kaminski, M. A.: An emendation of some Cretaceous species of "Reophax" (Foraminiferida) from northwest Europe and Poland, Proc. Fourth Internat. Worksh. agglut. Foram. Grzybowski Found., 3, 117-122, 1995.

Geroch, V. S. and Nowak, W.: Proposal of zonation for the Late Tithonian-Late Eocene, based upon arenaceous foraminifera from the Outer Carpathians, Poland, Benthos, 83, 225-239, 1984.

Grabert, B.: Phylogenetische Untersuchungen an Gaudryina und Spiroplectinata (Foram.), Abh. Senckenberg Naturforsch. Ges., 498, 1-71, 1959.

Gradstein, F., Kaminski, M. A., and Agterberg, F.: Biostratigraphy and paleoceanography of the Cretaceous seaway between Norway and Greenland. Earth-Sci. Rev., 46, 27-98, https://doi.org/10.1016/S0012-8252(99)00018-5, 1999.

Gradstein, F., Ogg, J. G., Schmitz, M., and Ogg, G.: Geologic Time Scale 2020, 2nd Edn., Elsevier, 1300 pp., 2020.

Gradstein, F. M. and Kaminski, M. A.: Taxonomy and biostratigraphy of new and emended species of Cenozoic deep-water agglutinated foraminifera from the Labrador and North Seas, Micropaleontology, 35, 75-92, 1989.

Grzybowski, J.: Otwornice czerwonych ilow z Wadowic, Rozprawy Wydzialu Matematyczno-Przyrodniczego, Akad. Umiej. Krakowie, serya 2, 30, 261-308, 1896.

Grzybowski, J.: Otwornice pokladow naftonosnych okolicy Krosna, Rozprawy Wydzialu Matematyczno-Przyrodniczego, Akad. Umiej. Krakowie, serya 2, 33, 257-305, 1898.

Grzybowski, J.: Otwornice warstw inoceramowych okolicy Gorlic, Rozprawy Wydzialu Matematyczno-Przyrodniczego, Akad. Umiej. Krakowie, 41, 201-286, 1901.

Haig, D. W. and Lynch, D. A.: A late early Albian marine transgressive pulse over northeastern Australia, precursor to epeiric basin anoxia: Foraminiferal evidence, Mar. Micropaleontol., 22, 331-362, 1993.

Hammer, Ø., Harper, D. A. T., and Ryan, P. D.: PAST: Paleontological Statistics Software Package for Education and Data Analysis, Pal. Electro., 4, 1-9, 2001. 
Hanzlíková, E.: Carpathian Upper Cretaceous foraminifera from Moravia (Turonian-Maastrichtian), Roz. Ústr. úst. Geol., 39, 5$160,1972$.

Haq, B. U.: Cretaceous eustasy revisited, Glob. Planet. Change, 113, 44-58, https://doi.org/10.1016/j.gloplacha.2013.12.007, 2014.

Haq, B. U., Hardenbol, J. A. N., and Vail, P. R.: Chronology of fluctuating sea levels since the Triassic, Science, 235, 1156-1167, 1987.

Hart, M. B., Fogerty, T., and Smart, C. W.: Foraminifera of the Gault Clay Formation: an update, Proc. Geol. Assoc., 131, 386-396, https://doi.org/10.1016/j.pgeola.2019.10.003, 2020.

Harloff, J. and Mackensen, A.: Recent benthic foraminiferal associations and ecology of the Scotia Sea and Argentine Basin, Mar. Micropaleontol., 31, 1-29, https://doi.org/10.1016/S03778398(96)00059-X, 1997.

Hemleben, C. and Troester, J.: Campanian-Maastrichtian deepwater foraminifers from Hole 543A, Deep Sea Drilling Project, Initial Rep, Deep Sea Drill. Proj. A, 78, 509-532, 1984.

Hercogová, J. and Kriz, J.: New Hemisphaerammininae (Foraminifera) from the Bohemian Cretaceous basin (Cenomanian), Věst. Ústr. úst. Geol., 58, 205-215, 1983.

Hetzel, A., März, C., Vogt, C., and Brumsack, H.-J.: Geochemical environment of Cenomanian-Turonian black shale deposition at Wunstorf (northern Germany), Cret. Res., 32, 480-494, https://doi.org/10.1016/j.cretres.2011.03.004, 2011.

Hiss, M.: Kreide, in: Geologischer Dienst Nordrhein-Westfalen, Geologie im Münsterland, Landesamt NRW, 41-63, 1995.

Hiss, M., Kaplan, U. and Wilmsen, M.: Herbram-Formation, in: Lithostratigraphie der norddeutschen Oberkreide, edited by: Niebuhr, B., Hiss, M., Kaplan, U., Tröger, K.-A., Voigt, S., Voigt, T., Wiese, F., and Wilmsen, M., Schrift.-R. Dt. Ges. Geowiss., 55, 30-32, 2007a.

Hiss, M., Kaplan, U., and Wilmsen, M.: Brochterbeck-Formation, in: Lithostratigraphie der norddeutschen Oberkreide, edited by: Niebuhr, B., Hiss, M., Kaplan, U., Tröger, K.-A., Voigt, S., Voigt, T., Wiese, F., and Wilmsen, M., Schrift.-R. Dt. Ges. Geowiss., 55, 34-35, 2007b.

Hiss, M., Kaplan, U., and Wiese, F.: Hesseltal-Formation, in: Lithostratigraphie der norddeutschen Oberkreide, edited by: Niebuhr, B., Hiss, M., Kaplan, U., Tröger, K.-A., Voigt, S., Voigt, T., Wiese, F., and Wilmsen, M., Schrift.-R. Dt. Ges. Geowiss., 55, 37-38, 2007c.

Holbourn, A. E. and Kaminski, M. A.: Lower Cretaceous deepwater benthic foraminifera of the Indian Ocean: a synthesis of DSDP \& ODP material, Grzybowski Found. Spec. Publ., 4, 172 pp., 1997.

Huss, F.: Otwornice aglutynujace serii podslaskiej jednostki roponosnej Weglowki (Polskie Karpaty Fliszowe), Agglutinated foraminifera of the oil-bearing subsilesian series in Weglowka (Polish Flysch Carpathians), Prace Geol., Polska Akad. Nauk, 34, 7-76, 1966.

Janetschke, N., Niebuhr, B., and Wilmsen, M.: Inter-regional sequence-stratigraphical synthesis of the Plänerkalk, Elbtal and Danubian Cretaceous groups (Germany): Cenomanian-Turonian correlations around the Mid-European Island, Cret. Res. ,56, 530-549, https://doi.org/10.1016/j.cretres.2015.04.007, 2015.

Jarvis, I., Gale, A. S., Jenkyns, H. C., and Pearce, M. A.: Secular variation in Late Cretaceous carbon isotopes: a new $\delta^{13} \mathrm{C}$ carbonate reference curve for the Cenomanian-
Campanian (99.6-70.6 Ma), Geol. Mag., 143, 561-608, https://doi.org/10.1017/S0016756806002421, 2006

Jenkyns, H.: Cretaceous anoxic events: from continents to oceans, J. Geol. Soc., 137, 171-188, https://doi.org/10.1144/gsjgs.137.2.0171, 1980.

Jones, R. W. and Charnock, M. A.: "Morphogroups" of agglutinated foraminifera, Their life positions and feeding habits and potential applicability in (paleo)ecological studies, Rev. Paleeobiol., 4, 311-320, 1985.

Jones, T. R. and Parker, W. K.: On the Rhizopodal fauna of the Mediterranean compared with that of the Italian and some other Tertiary deposits, Q. J. Geol. Soc., 16, 292-307, 1860.

Jorissen, J. J., Stiger, H. C., and Widmark, J. G. V.: A conceptual model explaining benthic foraminiferal microhabitats, Mar. Micropaleontol., 26, 3-15, 1995.

Józsa, Š.: Field stop 1: Vršatec - Upper Cretaceous microfauna of the oceanic red beds, in: Microfauna and biostratigraphy of the Mesozoic and Cenozoic formations of the Western Carpathians: Guidebook of the IWAF-10 field trip to Middle Valley and Malé Karpaty Mts, edited by: Soták, J., Hudáčková, N., and Michalík, J., Bratislava, Earth Sci. Inst., Slovak Acad. Sci., 41-47, 2017a.

Józsa, Š.: Deep water agglutinated foraminifera from the Jurassic/Cretaceous boundary and paleoenvironmental settings of the Maiolica type facies from the Czorstyn ridge (Pieniny Klippen Belt, Western Carpathians), Riv. Italiana Pal Strat., 123, 387398, 2017b.

Józsa, Š.: Early Tithonian deep-water colonization by benthic foraminifera in the Magura Basin (Pieniny Klippen Belt, Western Carpathians): a clue to the origins of deep-water foraminifera, Riv. Italiana Pal. Strat., 125, 401-420, 2019.

Józsa, Š., Schlögl, J., Meister, Ch., and Golej, M.: Lower Sinemurian - upper Pliensbachian smaller agglutinated foraminiferal events from the eastern part of the Pieniny Klippen Belt (Transcarpathian Ukraine, Western Carpathians), Micropaleontology, 64, 493-505, 2018.

Kaminski, M. A.: The year 2010 classification of the agglutinated foraminifera, in: Advances in agglutinated foraminiferal research: The Ninth International Workshop on Agglutinated Foraminifera, IWAF-9, edited by: Alegret, L. and Kaminski, M. A., Micropaleontology, 60, 89-108, 2014.

Kaminski, M. A. and Geroch, S.: A revision of foraminiferal species in the Grzybowski Collection, in: The Origins of Applied Micropaleontology: The School of Jozef Grzybowski, edited by: Kaminski, M. A., Geroch, S., and Kaminski, D., Grzybowski Found. Spec. Publ., 1, 293-323, 1993.

Kaminski, M. A. and Gradstein, F. M.: Atlas of Paleogene cosmopolitan deep-water agglutinated foraminifera, Grzybowski Found. Spec. Publ., 10, 1-547, 2005.

Kaminski, M. A., Gradstein, F., and Berggren, W.: Flysch-type agglutinated foraminiferal assemblages from Trinidad: taxonomy, stratigraphy and paleobathymetry, Abh. geol. Bundesanst., 41, 155-227, 1988.

Kaminski, M. A., Boersma, E., Tyszka, J., and Holbourn, A.: Response of deep-water agglutinated foraminifera to dysoxic conditions in the California Borderland basins, in: Proc. Fourth Internat. Worksh. agglut. Foram., edited by: Kaminski, M. A., Geroch, S., and Gasinski, M. A., Grzybowski Found. Spec. Publ., 3, 131-140, 1995. 
Kaminski, M. A., Cetean, C. G., and Neagu, T.: Rectogerochammina eugubina nov. gen., nov. sp., a new agglutinated foraminifer from the Upper Cretaceous of Gubbio, Italy, Rev. Micropaléont., 53, 121-124, 2010.

Kaminski, M. A., Cetean, C. G., Balc, R., and Coccioni, R.: Upper Cretaceous deep-water agglutinated foraminifera from the Contessa Highway Section, Umbria-Marche basin, Italy: taxonomy and biostratigraphy, in: Proc. Eighth Internat. Worksh. agglut. Foram., edited by: Kaminski, M. A. and Filipescu, S., Grzybwoski Found. Spec. Publ., 16, 71-106, 2011.

Kaminski, M. A., Alegret, L., Hikmahtiar, S., and Waśkowska, A.: The Paleocene of IODP Site U1511, Tasman Sea: A lagerstatte deposit for deep-water agglutinated foraminifera, Micropaleontology, 67, 341-364, 2021.

Kennedy, W. J., Gale, A., Lees, J., and Caron, M.: The global boundary stratotype section and point (GSSP) for the base of the Cenomanian Stage, Mont Risou, Hautes-Alpes, France, Episodes, 27, 21-32, 2004.

Krasheninnikov, V.: Cretaceous benthonic foraminifera, Leg 20, Deep Sea Drilling Project, Initial Rep. Deep Sea Drill. Proj., 20, 205-221, 1973.

Krasheninnikov, V.: Upper Cretaceous benthonic agglutinated foraminifera, Leg 27 of the Deep Sea Drilling Project, Initial Rep. Deep Sea Drill. Proj., 27, 631-661, 1974.

Kuhnt, W.: Agglutinated foraminifera of western Mediterranean Upper Cretaceous pelagic limestones (Umbrian Apennines, Italy, and Betic Cordillera, Southern Spain), Micropaleontology, 36, 297-330, 1990.

Kuhnt, W. and Kaminski, M. A.: Paleoecology of Late Cretaceous to Paleocene deep-water agglutinated foraminifera from the North Atlantic and Western Tethys, in: Paleoecology, biostratigraphy, paleoceanography and taxonomy of agglutinated foraminifera, edited by: Hemleben, C., Kaminski, M. A., Kuhnt, W., and Scott, D. B., NATO ASI Ser. C327, Kluwer Acad. Press, 433-506, 1990.

Kuhnt, W. and Kaminski, M. A.: Cenomanian to lower Eocene deep-water agglutinated foraminifera from the Zumaya section, northern Spain, Ann. Soc. Geol. Pol., 67, 257-270, 1997.

Kuhnt, W., Kaminski, M. A., and Moullade, M.: Late Cretaceous deep-water agglutinated foraminiferal assemblages from the North Atlantic and its marginal seas, Geol. Rundsch., 78, 1121-1140, 1989.

Kuhnt, W., Geroch, S., Kaminski, M. A., Moullade, M., and Neagu, T.: Upper Cretaceous abyssal claystones in the North Atlantic and Western Tethys: current status of biostratigraphical correlation using agglutinated foraminifers and palaeoceanographic events, Cret. Res., 13, 467-478, https://doi.org/10.1016/01956671(92)90011-E, 1992.

Leary, P. N.: The Late Cenomanian Anoxic Event; Implications for foraminiferal evolution, $\mathrm{PhD}$ thesis, Plymouth Univ., $325 \mathrm{pp}$., 1987.

Linnert, C., Mutterlose, J., and Erbacher, J.: Calcareous nannofossils of the Cenomanian/Turonian boundary interval from the Boreal Realm (Wunstorf, northwest Germany), Mar. Micropaleontol., 74, 38-58, 2010.

Loeblich, A. R. and Tappan, H.: Eleven new genera of foraminifera, Bull. U.S. Nat. Museum, 215, 223-232, 1957.
Loeblich, A. R. and Tappan, H.: A revision of mid-Cretaceous textularian foraminifers from Texas, J. Micropalaeontol., 1, 55-69, 1982.

Loeblich, A. R. and Tappan, H.: Foraminiferal genera and their classification, Springer, New York, 212 pp., 1987.

Magniez-Jannin, F.: Les foraminifères de l'Albien de l'Aube: paléontologie, stratigraphie, écologie, Cahiers Paléont., 416 pp., 1975.

Majzon, L.: Adatok egyes Kárpátaljai flis-rétegekhez, tekintettel a Globotruncanákra (Beitrage zur Kenntniss einiger Flysch Schichten des Karpaten-Vorlandes mit Rücksicht auf die Globotruncanen), A magyar Királyi Földtani Intézet, Évkönyve, Ann. Hungarian Geol. Inst., 37, 1-90, 1-177, 1943.

Maslakova, N.: Stratigrafiya i fauna melkikh foraminifer paleogenovykh otlozhenii Vostochnykh Karpat, Mater. Biostrat. zapad. oblastii Ukrain. SSR, 5, 5-132, 1955.

Melinte-Dobrinescu, M. C., Roban, R.-D., and Stoica, M.: Palaeoenvironmental changes across the Albian-Cenomanian boundary interval of the Eastern Carpathians, Cret. Res., 54, 6885, https://doi.org/10.1016/j.cretres.2014.10.010, 2015.

Meyer, T.: Biostratigraphische und sedimentologische Untersuchungen in der Plänerfazies des Cenoman von Nordwestdeutschland, Mitt. Geol. Inst., Univ. Hannover, 30, 1-114 1990.

Mjatliuk, E. V.: K vprosu o foraminiferakh c kremnevnym skeletom (On the question of foraminifera with a siliceous skeleton), Vop. Mikropaleont., 10, 255-269, 1966.

Morozova, V.: Foraminiferi nizhnemelovikh otlozhenii rayona g. sochi (Yugozapadnoi Kavkaz), Moscov. Obshch. Ispyt. Prirodi, Otdel Geol. Byull, 23, 23-43, 1948.

Murray, J. W., Alve, E., and Jones, B. W.: A new look at modern agglutinated benthic foraminiferal morphogroups: their value in palaeoecological interpretation, Palaeogeogr. Palaeocl., 309, 229-241, https://doi.org/10.1016/j.palaeo.2011.06.006, 2011.

Neagu, T.: Studiul foraminiferelor aglutinante din argilele Cretacic superiorare de pe Valea Sadovei (Cimpulung-Moldovenesc) si bazinul superior al vaii Buzauliu, Stud. Cerc. Geol., Acad. Rep. Pop. Rom-, Sect. Geol. Geogr. Inst. Geol. Geogr., 7, 45-81, 1962.

Neagu, T.: Micropaleontological and stratigraphical study of the Upper Cretaceous deposits between the upper valleys of the Buzau and Riul Negru Rivers (Eastern Carpathians), Bucarest, Mem. Inst. Geol., 12, 7-109, 1970.

Neagu, T.: Gerochammina n.g. and related genera from the Upper Cretaceous flysch-type benthic foraminiferal fauna, Eastern Carpathians - Romania, in: Paleoecology, biostratigraphy, paleoceanography and taxonomy of agglutinated foraminifera, edited by: Hemleben, C., Kaminski, M. A., Kuhnt, W., and Scott, D. B., NATO ASI Ser. C327, Kluwer Acad. Press, 245-265, 1990.

Niebuhr, B., Baldschuhn, R., Ernst, G., Walaszczyk, I., Weiss, W., and Wood, C. J.: The Upper Cretaceous succession (Cenomanian-Santonian) of the Staffhorst Shaft, Lower Saxony, northern Germany: integrated biostratigraphic, lithostratigraphic and downhole geophysical log data, Acta Geol. Pol., 49, 175213, 1999.

Niebuhr, B., Wiese, F., and Wilmsen, M.: The cored Konrad 101 borehole (Cenomanian-Lower Coniacian, Lower Saxony): calibration of surface and subsurface log data for the lower Upper Cretaceous of northern Germany, Cret. Res., 22, 643-674, https://doi.org/10.1006/cres.2001.0283, 2001. 
Olszewska, B. and Morgiel, J.: Biostratigraphy of the Polish External Carpathians based on agglutinated foraminifera, Micropaleontology, 27, 1-24, 1981.

Patterson, R. T., Haggart, J. W., and Dalby, A. P.: A guide to Late Albian-Cenomanian (Cretaceous) Foraminifera from the Queen Charlotte Islands, British Columbia, Canada. Paleont. Elec., 13, $1-28,2010$.

Perner, J.: Über die Foraminiferen des böhmischen Cenomans, Paleontogr. Bohemiae, 1, 65 pp., 1892.

Peryt, D., Lahodynsky, R., and Durakiewicz, T.: Deep-water agglutinated foraminiferal changes and stable isotope profiles across the Cretaceous-Paleogene boundary in the Rotwand-graben section, Eastern Alps (Austria), Palaeogeogr. Palaeocl., 132, 287307, https://doi.org/10.1016/S0031-0182(97)00056-4, 1997

Peryt, D., Alegret, L., and Molina, E.: Agglutinated foraminifers and their response to the Cretaceous/Paleogene (K/P) boundary event at Aïn Settara, Tunisia, in: Proc. Sixth Internat. Worksh. agglut. Foram., edited by: Bubík, M. and Kaminski, M. A., Grzybowski Found. Spec. Publ., 8, 393-412, 2004.

Philip, J. and Floquet, M.: Late Cenomanian (94.7-93.5), in: Atlas Peri-Tethys palaeogeographical maps, edited by: Dercourt, J., Gaetani, M., Vrielynck, B., Barrier, E., Biju-Duval, B., Brunet, M. F., Cadet, J. P., Crasquin, S., and Sandulescu, M., CCGM/CGMW, Paris, 129-136, 2000.

Püttmann, T. and Mutterlose, J.: Paleoecology of Late Cretaceous Coccolithophores: Insights From the ShallowMarine Record, Paleocean. Paleoclimat., 36, 1-20, https://doi.org/10.1029/2020PA004161, 2021.

Reuss, A. E.: Geognostische Skizzen aus Böhmen, Bd. 2: Die Kreidegebilde des westlichen Böhmens, ein monographischer Versuch. Nebst Bemerkungen über die Braunkohlenlager jenseits der Elbe und eine Uebersicht der fossilen Fischreste Böhmens, Medau \& Comp., Prag, 304 pp., 1844.

Reuss, A. E.: Die Versteinerungen der böhmischen Kreideformation, Mit Abbildungen der neuen oder weniger bekannten Arten, Abt. 1. Schweizerbart, Stuttgart, 58 pp., 1845.

Reuss, A. E.: Über die fossilen Foraminiferen und Entomostraceen der Septarianthone der Umgegend von Berlin, Z. Dt. Geol. Ges., 3, 49-91, 1851.

Reuss, A. E.: Die Foraminiferen der norddeutschen Hils und Gault, Sitz.-Ber. Akad. Wiss. Wien, mathe.-naturwiss. Klasse, 46, 5100, 1863.

Robaszynski, F., Gale, A. S., Juignet, P., Amedro, F., and Hardenbol, J.: Sequence stratigraphy in the Cretaceous series of the Anglo-Paris Basin: exemplified by the Cenomanian stage, in: Mesozoic and Cenozoic sequence stratigraphy of European basins, edited by: de Graciansky, P.-C., Hardenbol, J., Jacquin, T., and Vail, P. R., SEPM Spec. Publ., 60, 363-386, 1998.

Schmidt, U. and Jäger, R.: Bestimmungstabelle für einige inkrustierende Foraminiferen aus den Unterordnungen Textulariina und Rotaliina, Zitteliana, 20, 171-178, 1993.

Schubert, R. J.: Neue und interessante Foraminiferen aus dem südtiroler Alttertiär, Beitr. Paläont. Geol. Österr.-Ungarn Orients, 14, 9-26, 1902.

Schultze, F. E.: Zoologische Ergebnisse der Nordseefahrt vom 21. Juli bis 9. September 1872: 1. Rhizopoden. J.-Ber. Comm. Wiss. Unter. Dt. Meere, 2-3, 1875.

Seibertz, E.: Geologie der Mergelkalk-Lagerstätte Wunstorf (Oberkreide, Niedersachsen), Phase IV. Auswer- tung der Bohrungen aus den Jahren 2011 und 2012, Dr. Moll Bericht 2688/12/11, Isernhagen, 61 pp. https://doi.org/10.13140/RG.2.2.29006.77122, 2013.

Setoyama, E., Kaminski, M. A., and Tyszka, J.: Late Cretaceous agglutinated foraminifera and implications for the biostratigraphy and palaeobiogeography of the southwestern Barents Sea, in: Proc. Eighth Internat. Worksh. agglut. Foram., edited by: Kaminski, M. A. and Filipescu, S., Grzybowski Found. Spec. Publ., 20, 251-309, 2011.

Setoyama, E., Kaminski, M. A., and Tyska, J.: Late CretaceousPaleogene foraminiferal morphogroups as palaeoenvironmental tracers of the rifted Labrador margin, northern proto-Atlantic, in: Proc. Ninth Internat. Worksh. agglut. Foram., edited by: Kaminski, M. A. and Alegret, L., Grzybowski Found. Spec. Publ., 22, 179-220, 2017.

Skelton, P. W.: Introduction to the Cretaceous, in: The cretaceous world, edited by: Skelton, P. W., Cambridge Univ. Press., 9-41, 2003.

Sliter, W. V.: Upper Cretaceous foraminifera from the southern California and northwestern Baja California, Mexico, Univ. Kansas Paleont. Contrib., 49, 141 pp., 1968.

Tappan, H.: Foraminifera from the Duck Creek formation of Oklahoma and Texas, J. Paleont., 17, 467-517, 1943.

Tappan, H.: Cretaceous biostratigraphy of northern Alaska. Bull. Amer. Assoc. Petroleum Geologists, 44, 273-297, 1960.

Ten Dam, A.: Les foraminifères de l'Albien des Pays-Bas, Soc. géol. France, 29, 1-66, 1950.

Tyszka, J.: Foraminiferal response to seasonality modulated by orbital cycles in the Cretaceous mid-latitudes: The Albian record from the Lower Saxony Basin, Palaeogeogr. Palaeocl., 276, 148159, https://doi.org/10.1016/j.palaeo.2009.03.006, 2009.

Tyszka, J. and Thies, A.: Spiroplectinata, key benthic foraminifer genus for palaeoceanographic reconstruction of the Albian Lower Saxony Basin, Palaeogeogr. Palaeocl., 174, 199-220, https://doi.org/10.1016/S0031-0182(01)00294-2, 2001.

Van Den Akker, T. J. H. A., Kaminski, M. A., Gradstein, F. M., and Wood, J.: Campanian to Palaeocene biostratigraphy and palaeoenvironments in the Foula Sub-basin, west of the Shetland Islands, UK, J. Micropalaeontol., 19, 23-43, https://doi.org/10.1144/jm.19.1.23, 2000.

van der Zwaan, G. J., Duijnstee, I. A. P., Dulk, M. den, Ernst, S. R., Jannink, N. T., and Kouwenhoven, T. J.: Benthic foraminifers: proxies or problems? A review of paleocological concepts, Earth-Sci. Rev., 46, 213-236, 1999.

van Helmond, N. A. G. M., Sluijs, A., Sinninghe Damsté, J. S., Reichart, G.-J., Voigt, S., Erbacher, J., Pross, J., and Brinkhuis, H.: Freshwater discharge controlled deposition of CenomanianTuronian black shales on the NW European epicontinental shelf (Wunstorf, northern Germany), Clim. Past, 11, 495-508, https://doi.org/10.5194/cp-11-495-2015, 2015.

Vašíċek, M.: Poznámky k mikrobiostratigrafii magurského flyše na Moravě, Věst. Stát. Geol. Úst. ěsk. Rep., 22, 235-256, 1947.

Voigt, S. and Hilbrecht, H.: Late Cretaceous carbon isotope stratigraphy in Europe: correlation and relations with sea level and sediment stability, Palaeogeogr. Palaeocl., 134, 39-59, https://doi.org/10.1016/S0031-0182(96)00156-3, 1997.

Voigt, S. and Wiese, F.: Evidence for Late Cretaceous (Late Turonian) climate cooling from oxygen-isotope variations and palaeo- 
biogeographic changes in Western and Central Europe, J. Geol. Soc., 157, 737-743, https://doi.org/10.1144/jgs.157.4.737, 2000.

Voigt, S., Gale, A. S., and Flögel, S.: Midlatitude shelf seas in the Cenomanian-Turonian greenhouse world: Temperature evolution and North Atlantic circulation, Paleoceanography, 19, 117, https://doi.org/10.1029/2004PA001015, 2004.

Voigt, S., Gale, A. S., and Voigt, T.: Sea-level change, carbon cycling and palaeoclimate during the Late Cenomanian of northwest Europe; an integrated palaeoenvironmental analysis, Cret. Res., 27, 836-858, https://doi.org/10.1016/j.cretres.2006.04.005, 2006.

Voigt, S., Aurag, A., Leis, F., and Kaplan, U.: Late Cenomanian to Middle Turonian high-resolution carbon isotope stratigraphy: New data from the Münsterland Cretaceous Basin, Germany, Earth Planet. Sc. Let., 253, 196-210, https://doi.org/10.1016/j.epsl.2006.10.026, 2007.

Voigt, S., Wagreich, M., Surlyk, F., Walaszczyk, I., Uličný, D., and Čech, S.: Cretaceous, in: Geology of central Europe, edited by: McCann, T., London, The Geological Society, Vol. 2, 923-997, 2008a.

Voigt, S., Erbacher, J., Mutterlose, J., Weiss, W., Westerhold, T., Wiese, F., Wilmsen, M., and Wonik, T.: The CenomanianTuronian of the Wunstorf section (North Germany): global stratigraphic reference section and new orbital time scale for Oceanic Anoxic Event 2, Newsl. Strat., 43, 65-89, 2008b.

Voloshina, A.: Ataxophragmeids from Upper Cretaceous Deposits in the Volyn-Podol Margin of the Russian Platform, Tr. Ukr. NIGRI (Proc. Ukrainian SSr Geol. Paleont. Inst.), 27, 55-130, 1972.

Waśkowska, A.: Distribution of the agglutinated foraminifer Ammolagena clavata (Jones and Parker) in Western Tethyan Upper Cretaceous and Paleogene deep-water deposits (Outer Carpathians, Poland), Micropaleontology, 60, 77-88, 2014.

Waters, J. A.: A group of foraminifera from the Dornick Hills Formation of the Ardmore Basin, J. Paleont., 1, 129-133, 1927.

Weidich, K. F.: Die kalkalpine Unterkreide und ihre Foraminiferenfauna, Zitteliana, 17, 1-312, 1990.

Wiese, F.: The Söhlde Formation (Cenomanian, Turonian) of NW Germany: Shallow Marine Pelagic Red Beds, in: Cretaceous Oceanic Red Beds, edited by: Hu, X., Wang, C., Scott, R. W., Wagreich, M., and Jansa, L., Soc. Econ. Paleontologists Mineralogists Spec. Publ., 91, 153-170, 2009.

Wiese, F. and Voigt, S.: Late Turonian (Cretaceous) climate cooling in Europe: faunal response and possible causes, Geobios, 35, 6577, https://doi.org/10.1016/S0016-6995(02)00010-4, 2002.

Wiese, F., Hiss, M. and Voigt, S.: Söhlde-Formation, in:, Lithostratigraphie der norddeutschen Oberkreide, edited by: Niebuhr, B., Hiss, M., Kaplan, U., Tröger, K.-A., Voigt, S., Voigt, T., Wiese, F., and Wilmsen, M. Schrift.-R. Dt. Ges. Geowiss., 55, 40-41, 2007.
Wiese, F., Zobel, K., and Keupp, H.: Calcareous dinoflagellate cysts and the Turonian nutrient crisis - Data from the upper Turonian of the Lower Saxony Basin (northern Germany), Cret. Res., 56, 673-688, https://doi.org/10.1016/j.cretres.2015.06.007, 2015.

Wiese, R., Renaudie, J., and Lazarus, D. B.: Testing the accuracy of genus-level data to predict species diversity in Cenozoic marine diatoms, Geology, 44, 1051-1054, https://doi.org/10.1130/G38347.1, 2016.

Wilmsen, M.: Sequence stratigraphy and palaeoceanography of the Cenomanian Stage in northern Germany, Cret. Res., 24, 525568, https://doi.org/10.1016/S0195-6671(03)00069-7, 2003.

Wilmsen, M.: Integrated stratigraphy of the upper Lower-lower Middle Cenomanian of northern Germany and southern England, Acta Geol. Pol., 57, 263-279, 2007.

Wilmsen, M.: An Early Cenomanian (Late Cretaceous) maximum flooding bioevent in NW Europe: Correlation, sedimentology and biofacies, Palaegeogr. Palaeocl., 258, 317-333, https://doi.org/10.1016/j.palaeo.2007.11.007, 2008.

Wilmsen, M.: Origin and significance of Late Cretaceous bioevents: Examples from the Cenomanian, Acta Palaeont. Pol., 57, 759771, 2012.

Wilmsen, M. and Hiss, M.: Baddeckenstedt-Formation, in: Lithostratigraphie der norddeutschen Oberkreide, edited by: Niebuhr, B., Hiss, M., Kaplan, U., Tröger, K.-A., Voigt, S., Voigt, T., Wiese, F., and Wilmsen, M., Schrift.-R. Dt. Ges. Geowiss., 55, 32-33, 2007.

Wilmsen, M. and Niebuhr, B.: Stratigraphic revision of the upper Lower and Middle Cenomanian in the Lower Saxony Basin (northern Germany) with special reference to the Salzgitter area, Cret. Res., 23, 445-460, https://doi.org/10.1006/cres.2002.1014, 2002.

Wilmsen, M. and Voigt, T.: The middle-upper Cenomanian of Zilly (Sachsen-Anhalt, northern Germany) with remarks on the Pycnodonte Event, Acta Geol. Pol., 56, 17-31, 2006.

Wilmsen, M., Niebuhr, B., and Hiss, M.: The Cenomanian of northern Germany: facies analysis of a transgressive biosedimentary system, Facies, 51, 242-263, https://doi.org/10.1007/s10347005-0058-5, 2005.

Wilmsen, M., Niebuhr, B., Wood, C. J., and Zawischa, D.: Fauna and palaeoecology of the Middle Cenomanian Praeactinocamax primus Event at the type locality, Wunstorf quarry, northern Germany, Cret. Res., 28, 428-460, https://doi.org/10.1016/j.cretres.2006.07.004, 2007.

Wilmsen, M., Schumacher, D., and Niebuhr, S.: The early Cenomanian crippsi Event at Lüneburg (Germany): palaeontological and stratigraphical significance of a widespread Late Cretaceous bioevent, Palaeobiodiv. Palaeoenviron., 101, 1-20, 2021. 